\title{
糠味䁚, 紐菌學的研究
}

\section{第 1 編 糠味嚊ヨリ分離培養セル細菌二關 \\ スル研究}

篮原小兒保健研觉所

\author{
伊庭吉雄
}

\section{【内容 抄 錄】}

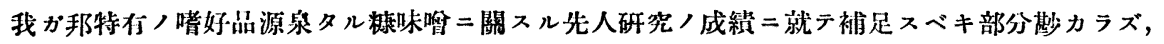

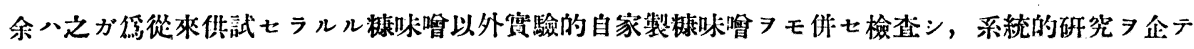
テ得ルトコロアリ．茲二辞報スル所以ナリ㚐.

目

\begin{tabular}{|c|c|}
\hline 緒 & $\overline{\bar{\theta}}$ \\
\hline 第 1 幛 & 倛試棣味面竝=細菌分陮法 \\
\hline 第 2 章 & 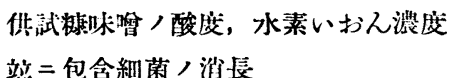 \\
\hline
\end{tabular}

第3 章 槺味然ョリ分離セ几諸菌ノ性狀

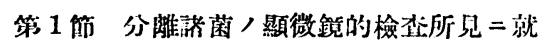
$\bar{\tau}$

\section{緒}

\section{次}
第 2 節 分㒕菏菌/培養上珄啠二就テ
第 3 籐 分離諸菌/熱二對ス儿抵抗 $=$ 就示
第 4 䈱 分離諸菌 酸及ビあるかり=對 几㮩度二就テ

第 5 管 分離諸菌 / 動物二對スル清性二就

總括

糠味䁚漬之邦人日常ノ副食物トシテ，又嗜好品トシテモ缺クベカラザルモノ ノ一二屬ス，而シテ之ガ原料站二製法ヨリ見ルモ或、日夕污染手指ノ拆入又、

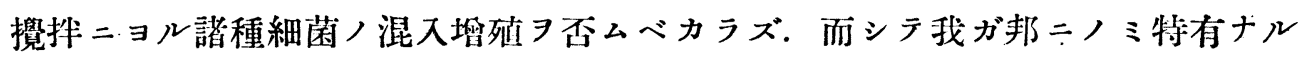

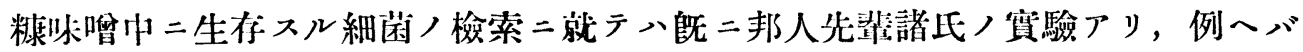

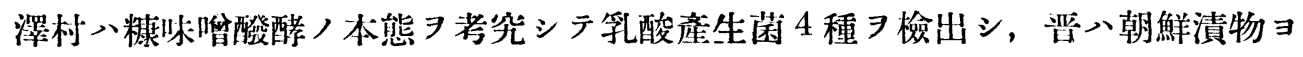
リ11種ノぐらむ陽性桿菌及ビ 2 種ノぐらむ陽性球菌 7 分離セリ。最近岡村八糠 味唄中二ぐらむ陽性球菌及ビ四聯球菌，ぐらさ陽性桿菌站二ぐらむ陰性桿菌等

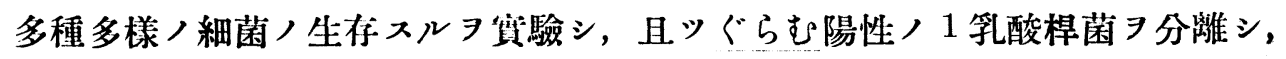




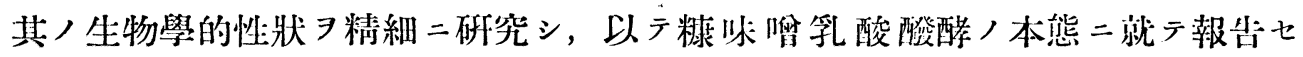
リ。余モ亦糠味嚊二關スル賽驗的研究二着手シ, 特二消化器 7 侵襲スル病原菌 ノ糠味嗊中二於ヶル運命二就テ研究セントシ，一般邦人家庭二於テ使用中ノモ ノ, 及ビ余ガ新タ二呼究用トシテ調製セル糠味㴰二就テ夫々包含細菌 是等多數ノ分離細菌二就テ系統的研究 報告セントス.

\section{- 第 1 章 供試糠味噲竝二細菌分離法}

余、先ヅ邦人家庭二於テ使用セラルル5種ノ糠味骝二就テ包含細菌 リ。而シテ是等家庭二於ケル糠味㲘ハ何レモ米棣及ビ監

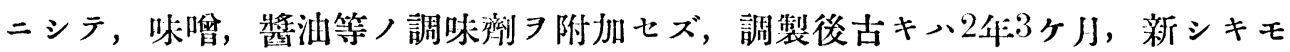
ノハ23日ヨ經タルモノナリ。

次デ余ハ滅菌ちりんでる 3 種, 實驗用糠味噲刃調製シ，供試材料トセリ。

(A) 米糠 $100 \mathrm{~g}$, 監 $10 \mathrm{~g}$, 水 $200 \mathrm{cc}$.

(B) 米糠 $100 \mathrm{~g}$, 監 $30 \mathrm{~g}$, 水 $200 \mathrm{cc}$.

(C) 米糠 $100 \mathrm{~g}$, 監 $60 \mathrm{~g}$ ，水 $200 \mathrm{cc}$.

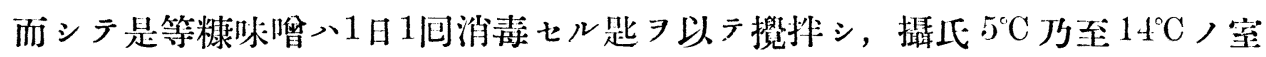
温二放置シ試驗二供セリ.

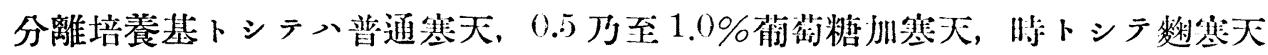

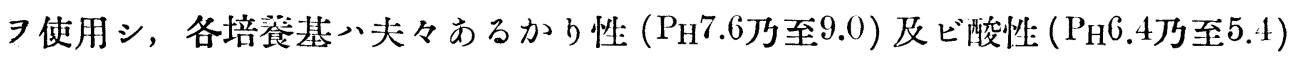
ノ 2 種 $习$ 用年タリ.

光ヅ被檢糠味嗊 9 量取シ滅菌蒸溜水 9 以 10 倍二稀釋シ, 之ガ上淸液ノ一定 量 $习$ 前記各培養基本板面二滴下シ, こんらーぢ棒 淸液 $コ$ 以テ豫メ溶解シ, 約 $45^{\circ} \mathrm{C}=$ 冷却七ル培篒基二混ジ, 隇菌しゃ一れ二注加

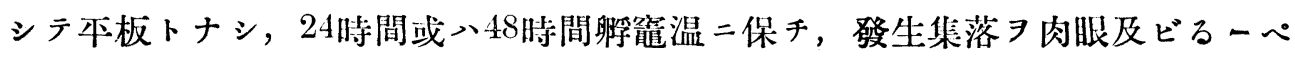
ヨ以テ檢シ，苟クモ異レリト思惟スル集落、悉ク之ヨ釣取シ，夫々新タ二培鉴 基二移植シ分離培䍚二附シタリ。 


佊庭吉雄述

\section{第 2 章 供試糠味噌ノ總酸度, 水素いお ん浱度竝二包含細菌ノ消長}

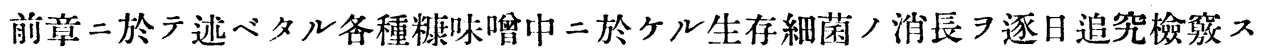

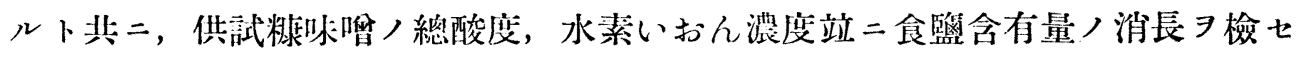

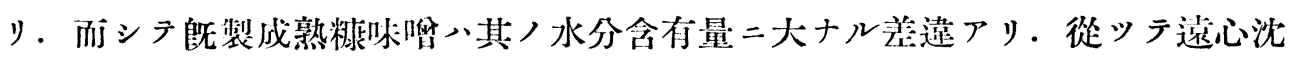

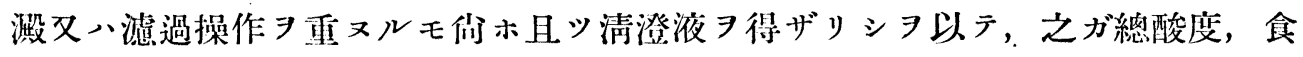

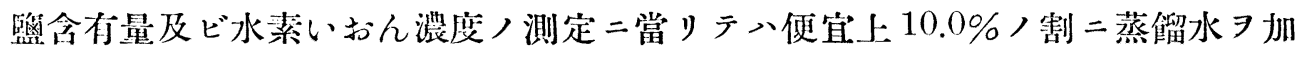
へテ稀釋，滤過シ，滤液二就テ試驗七り．即于總酸度ノ測定八胃液ノ夫レ二倣

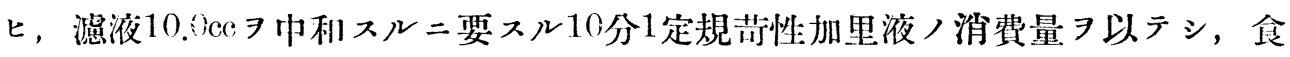

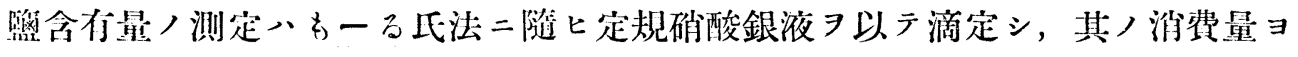

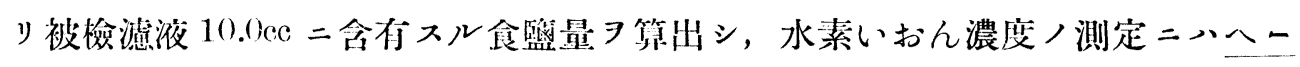

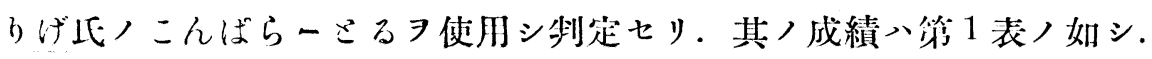

第 1 表

\begin{tabular}{|c|c|c|c|c|c|c|}
\hline 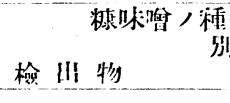 & 既製嵻味嘫 I & " & III & IIII & " & $V$ \\
\hline 總陵度 & 4.4 & 3.2 & 2.8 & 2.0 & 1.8 & \\
\hline 企監量 & 0.13 & 0.11 & 0.11 & 0.07 & 0.02 & \\
\hline 水素いお人溸度 & 4.2 & 4.2 & 4.0 & 4.4 & 4.2 & \\
\hline
\end{tabular}

次デ余ノ調製セル實驗用棣味骝二就テハ, 調製直後ヨリ熟成迄ノ間, 日 フテ生存細菌ヨ分離スルト其二其ノ總酸度及ビ水素いお九濃度习前記ノ法二依 テ测定セり。其ノ成績八第 2 表ノ如シ。

第 2 表 


\begin{tabular}{|c|c|c|c|c|c|c|c|c|c|c|c|c|c|}
\hline & 檢 & 槺 & 味 & 嘫 & & 棣 & 味 & 㕰 & & 栐 & 味 & 嘫 & \\
\hline 目 & & 第 & & 第 & 回 & 第 & [四] & 第 & [ii] & 第 & 回 & 第 2 & \\
\hline 別 & & 總酸度 & $\mathrm{P}_{\mathrm{H}}$ & 總酸度 & $P_{H}$ & 總酸度 & $\mathrm{P}_{\mathrm{H}}$ & 總酸度 & $\mathrm{P}_{\mathrm{H}}$ & 總酸度 & $\mathrm{P}_{\mathrm{H}}$ & 總酸度 & $\mathrm{P}_{\mathrm{H}}$ \\
\hline 調 製 & 後 & 0.25 & 6.5 & 0.18 & 6.6 & 0.24 & 6.6 & 0.22 & 6.4 & 0.30 & 6.5 & 0.20 & 6.4 \\
\hline 第 2 & 日 & 0.55 & 5.4 & 0.94 & & 0.55 & 5.4 & 0.59 & & 0.50 & 5.4 & 0.60 & \\
\hline 第 3 & 日 & 0.76 & & 1.05 & 5.2 & 0.60 & & 0.55 & 5.6 & 0.46 & & 0.40 & 5.6 \\
\hline 第 4 & 日 & 0.70 & & 1.00 & & 0.60 & & 0.64 & & 0.51 & & 0.40 & \\
\hline 第 5 & 日 & 0.90 & & 1.12 & & 0.56 & & 0.85 & & 0.50 & & 0.42 & \\
\hline 第 6 & 日 & 1.20 & & 1.10 & & 0.58 & & 0.82 & & 0.55 & & 0.50 & \\
\hline 第 7 & 日 & 1.56 & & 1.22 & & 0.60 & & 0.80 & & 0.58 & & 0.46 & \\
\hline 第 8 & 日 & 1.70 & & 1.40 & & 0.68 & & 1.00 & & 0.62 & & 0.42 & \\
\hline 第 9 & 日 & 1.86 & 4.6 & 1.33 & 5.4 & 0.78 & 5.4 & 1.12 & 5.4 & 0.60 & 5.4 & 0.42 & 5.5 \\
\hline 第 10 & 日 & 2.00 & & 1.52 & & 0.80 & & 1.05 & & 0.64 & & 0.42 & \\
\hline 第 11 & 日 & 2.28 & 4.4 & 1.60 & 4.7 & 0.84 & 5.4 & 1.26 & 5.4 & 0.60 & 5.4 & 0.48 & 5.6 \\
\hline 第 12 & 日 & 2.40 & & 1.72 & & 0.82 & & 1.36 & & 0.50 & & 0.50 & \\
\hline 第 13 & 日 & 2.80 & & 1.90 & & 0.80 & & 1.44 & & 0.52 & & 0.48 & \\
\hline 筹 14 & 日 & 2.80 & & 2.00 & & 0.80 & & 1.64 & & 0.52 & & 0.64 & \\
\hline 第 15 & 日 & 2.78 & & 2.22 & & 0.82 & & 1.80 & & 0.52 & & 0.81 & \\
\hline 第 16 & 日 & 2.63 & 4.2 & 2.26 & 4.6 & 0.94 & 5.4 & 1.64 & 4.8 & 0.50 & 5.5 & 0.64 & 5.2 \\
\hline 第 17 & 日 & 2.81 & & 2.80 & & 0.80 & & 1.80 & & 0.56 & & 0.52 & \\
\hline 第 18 & 日 & 2.80 & & 2.72 & & 1.02 & & 1.54 & & $0.6 \mathrm{~J}$ & & 0.62 & \\
\hline 第 19 & 日 & 2.80 & & 2.62 & 4.4 & 0.80 & & 1.52 & 4.4 & 0.60 & & $0.6^{\prime}$ & 4.5 \\
\hline 第 20 & 日 & $2 . \delta 2$ & 4.2 & 2.78 & & 0.76 & 4.6 & 0.98 & & 0.48 & 4.6 & 0.72 & \\
\hline 第 21 & 日 & 2.80 & & 2.78 & & 0.80 & & 1.00 & & 0.53 & & 0.76 & \\
\hline 第 22 & 日 & 2.74 & & 2.80 & 4.2 & 0.84 & & 1.20 & 4.4 & 0.50 & & 0.53 & 4.5 \\
\hline 第 23 & 日 & 2.78 & 4.2 & 2.80 & & 0.74 & 4.4 & 1.35 & & 0.44 & 4.6 & 0.52 & \\
\hline
\end{tabular}

即チ既製成熟糠味噃 $10.0 \%$ 液二於ヶル總酸度 1.8 万至 4.4 ，食監量 $0.024 \mathrm{~g}$ ， 乃至 $0.133 \mathrm{~g}$ ，水素いおん濃度ハ 4.0 乃至 4.4 ナリ。而シテ余ノ調製セル實驗周， モノ八, 何レモ調製後 24 時間ニシテ總酸度, 水素いおん濃度共二强キ上年ヨ示 シ, 爾後逐日上豕シ, 十數日二至りテ全少熟成ス.

次二余入前記 5 種ノ既製成熟糠味骝中二於ヶル生存細菌, 及ビ余ノ調製セル 


$$
\text { 仍庭吉逃 }
$$

實驗用糠味頪中二於ヶル生存細菌ノ消長 $タ$ 知ラントシ, 特二實驗用糠味噃二就 テハ日々醴酵過程 ヨ追ヒテ前愐記載ノ分離法二隨七檢查 $コ$ 續行セリ. 其ノ成績 八第3表乃至第6表ノ如シ.

第 3 裴 既製糠味骝ヨ以テセル試驗

\begin{tabular}{|c|c|c|c|c|c|c|c|c|c|c|c|c|c|c|c|c|c|c|}
\hline \multicolumn{2}{|l|}{ 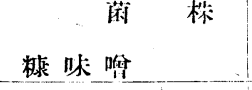 } & 1 & 2 & 3 & \begin{tabular}{l|l}
45 \\
\end{tabular} & 5 & $\begin{array}{ll}6 & 7\end{array}$ & 8 & 9 & $10 \mid 1$ & \begin{tabular}{l|l|}
11 & 12
\end{tabular} & 13 & 141 & $\begin{array}{ll}15 & 16\end{array}$ & 17 & \begin{tabular}{l|l}
$18 \quad 19$ \\
\end{tabular} & 20 & $\begin{array}{ll}21 & 22 \\
\end{array}$ \\
\hline $\left.\begin{array}{c}\text { 既 製 } \\
\text { 槺味㗱 }\end{array}\right\}$ I & 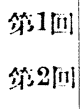 & & + & & + & & & & + & $\begin{array}{l}H \\
H\end{array}$ & & & & & & + & & \\
\hline $\mathbb{I}$ & $\begin{array}{l}\text { 第1[i] } \\
\text { 第2[i] }\end{array}$ & + & & & $\begin{array}{l}+ \\
+\end{array}$ & & + & & & $\begin{array}{l}H \\
H\end{array}$ & & & $\begin{array}{l}H \\
+\end{array}$ & & & + & & + \\
\hline " & $\begin{array}{l}\text { 第1们 } \\
\text { 第2 } 2[\text { [! }\end{array}$ & & & + & & & & & & $\begin{array}{l}+ \\
+\end{array}$ & + & & & $\begin{array}{l}+ \\
+\end{array}$ & & & & \\
\hline IIII & $\begin{array}{l}\text { 第1回 } \\
\text { 第2 } 2[\square]\end{array}$ & & & & & + & + & & & $\begin{array}{l}H \\
H\end{array}$ & + & & & & & H & & \\
\hline " V & 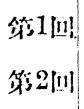 & & & & & & + & & & $\begin{array}{l}H \\
H\end{array}$ & & + & $\begin{array}{l}+ \\
+\end{array}$ & & + & & & + \\
\hline
\end{tabular}

第 4 表 赛驗用粶味稩 $\mathrm{A} \ni$ 以テセル試驗

\begin{tabular}{|c|c|c|c|c|c|c|c|c|c|c|c|c|c|c|c|c|c|c|c|c|c|c|c|}
\hline 檢查自 & & 株 & 1 & 2 & 3 & 4 & 5 & 6 & 7 & 8 & 9 & 10 & 11 & 12 & 13 & 14 & \begin{tabular}{l|l}
15 & 1
\end{tabular} & \begin{tabular}{l|l}
16 & 17
\end{tabular} & $\begin{array}{l}718 \\
\end{array}$ & $\mid 19$ & 20 & \begin{tabular}{l|l}
21 & 2
\end{tabular} & 22 \\
\hline 調 & 製 & 後 & & & & + & & & & & & & + & & & $H$ & & & & + & & & \\
\hline & 2 & 日 & & & & + & & & & & & & & & & $H$ & & & & & & & \\
\hline 第 & 3 & 日 & & & & & & & & & & + & & & + & + & & + & & & & + & \\
\hline 第 & 4 & 日 & & + & & + & & & & & & + & + & & + & & & & & + & & + & + \\
\hline 第 & 5 & 日 & & & & + & & & & & & $H$ & & & & & + & & & & & & \\
\hline 第 & 6 & 日 & & & & & & & & & & $H$ & & & & & $H$ & & & & & & \\
\hline 第 & 7 & 日 & & & & & & & & & & WI & & & & + & & & & & & & \\
\hline 第 & 8 & 日 & & & & & + & & & & & $H$ & & & & & & & & & & & \\
\hline
\end{tabular}




\begin{tabular}{|c|c|c|c|c|c|c|c|c|c|c|c|c|c|c|c|c|c|c|c|c|c|c|}
\hline 檢查目 & & 株 & 1 & 2 & 3 & 4 & 5 & 6 & 7 & 8 & 9 & 10 & 11. 1 & \begin{tabular}{|l|l|}
12 & 13
\end{tabular} & 14 & 15 & 16 & 17 & 81 & \begin{tabular}{l|l}
9 & 2
\end{tabular} & 021 & 22 \\
\hline 第 & 9 & 日 & & & & & & & + & & & $H$ & & & & + & & & & & & \\
\hline 筷 & 10 & 日 & & & & & & & + & & & $H$ & & & & $H$ & & & & & & \\
\hline 第 & 11 & E & & & & & & & & & & $H$ & & & & & & & & & & \\
\hline 第 & 12 & 白 & & & & & & & & & + & $H$ & & & & & & & & & & \\
\hline 第 & 13 & 日 & & & & & & & & & & $H$ & & & & & & & & + & & \\
\hline 第 & 14 & 日 & & & & & & & & & & $H$ & & & & & & & & & & \\
\hline 第 & 15 & 日 & & & & & & & & & + & $H$ & & & & & & & & & & \\
\hline 筷 & 16 & 日 & & & & + & & & & & & $H$ & & & & & & & & + & & \\
\hline 第 & 17 & 日 & & & & & & & & & & $H$ & & & & & & & & & & \\
\hline 第 & 18 & 日 & & & & & & & & & & $H$ & & & & & & & & & & \\
\hline 第 & 19 & 日 & & & & + & & & & & & $H$ & & & & & & & & & & \\
\hline 第 & 20 & 日 & & & & & & & & & & $\mathrm{HI}$ & & & & & & & & & & \\
\hline
\end{tabular}

\section{第 5 表 筫驗用糠味唵 B ヨ以テセル試驗}

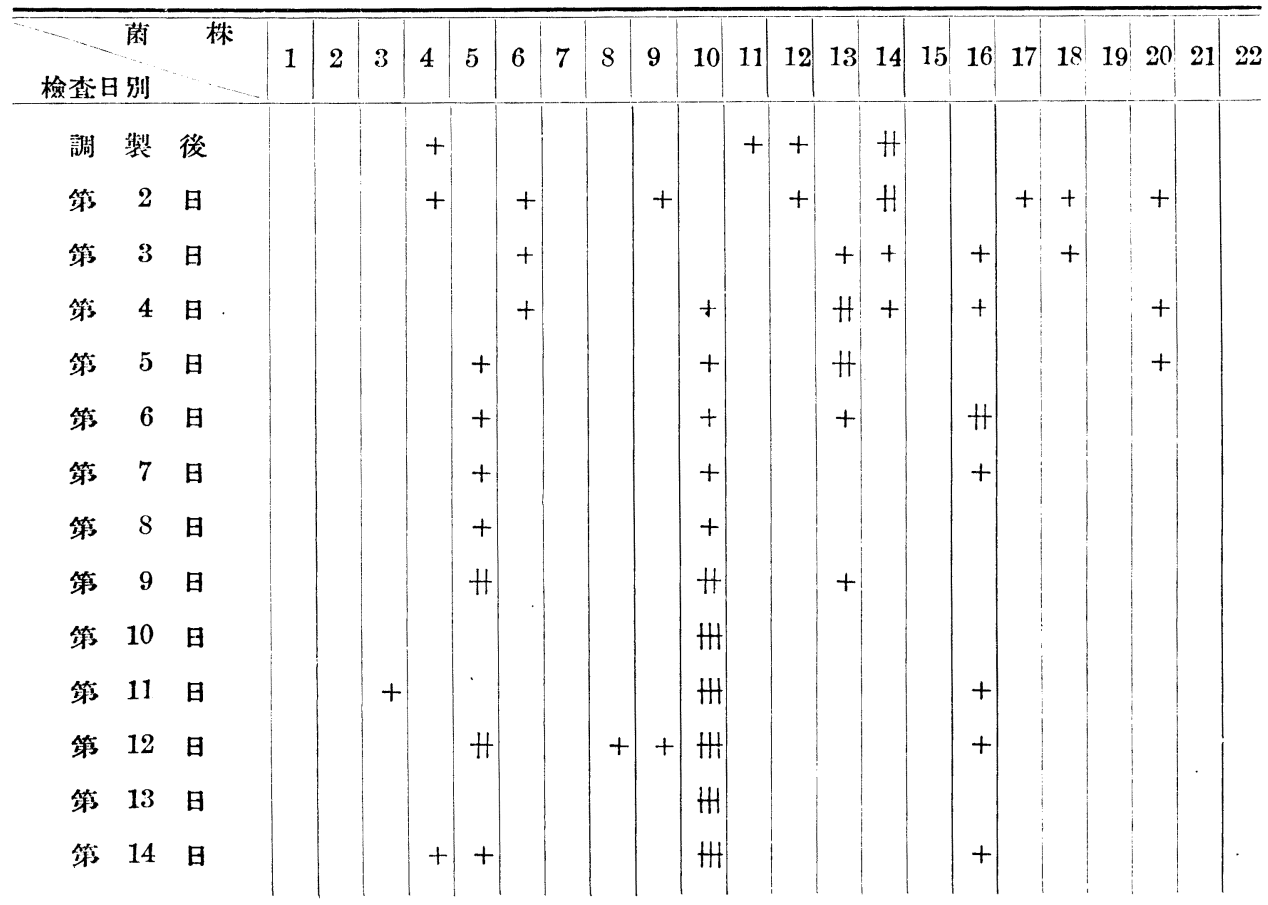


作庭吉述

(1473)

\begin{tabular}{|c|c|c|c|c|c|c|c|c|c|c|c|c|c|c|c|c|c|c|c|c|c|c|}
\hline 檢查日 & & $\begin{array}{c}\text { 株 } \\
\end{array}$ & 1 & 2 & 3 & 4 & 5 & 6 & 7 & 8 & 9 & 10 & 11 & 12 & 131 & \begin{tabular}{l|l}
14 & 1
\end{tabular} & 516 & $6 \mid 17$ & 18 & 19 & \begin{tabular}{ll|}
20 & 21 \\
\end{tabular} & 22 \\
\hline 第 & 15 & 日 & & & & & & & & & & H & & & & & & & & & & \\
\hline 第 & 16 & 日 & & & & & & & & & & $\mathrm{H}$ & & & & & + & & & & & \\
\hline 笘 & 17 & 日 & & & & & + & & & & & $\mathrm{HH}$ & & & & & & & & & & \\
\hline 第 & 18 & 日 & & & & & & & & & & $H$ & & & & & & & & & & \\
\hline 第 & 19 & 日 & & & & & & & & & & $H$ & & & & & & & & & & + \\
\hline 第 & $\mathbf{2 0}$ & 日 & & & & & & & & & & $\mathrm{WI}$ & & & & & & & & & & \\
\hline
\end{tabular}

第 6 表 貫驗用糠味嚊 $\mathrm{C}$ ヨ以テセル試驗

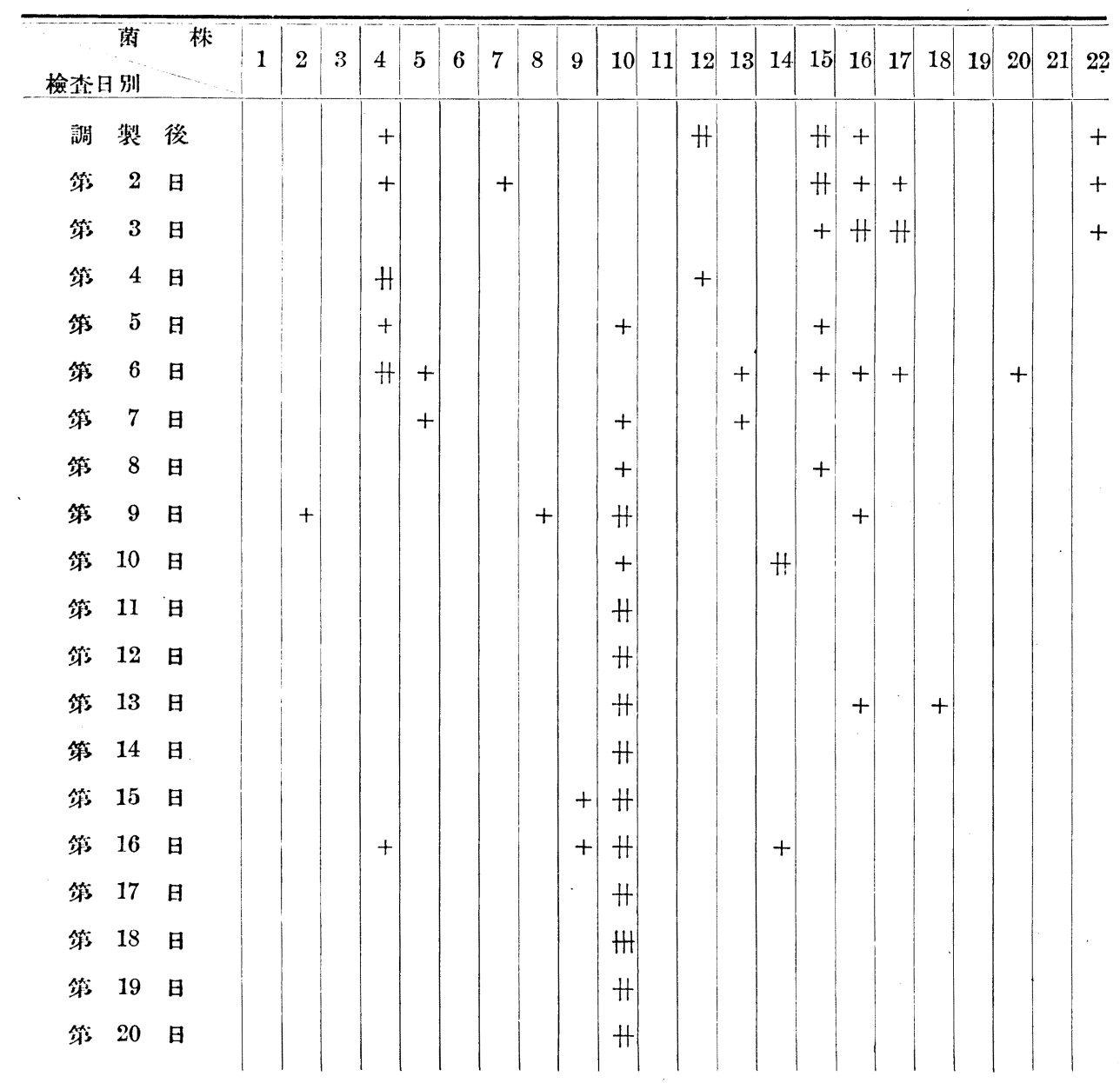


即チ余ガ分離シ得タル菌株ハ合計 22 株ニシテ,ぐらむ陽性球菌 7 株, 雙球菌 及ビ四聯球菌各 1 株, ぐらむ㓌性桿菌 6 株, ぐらむ陽性桿菌 7 株ナリ。而シテ 第 3 表二示セル如ク既製成熟糠味骝二於テ檢查每回證明セラルルモノ八獨り第 10號菌ノミニシテ, 爾狳ノ菌株、每包發生數動搖シ, 或、出現率甚 ダ不定ナ リ。而シテ實驗用糠味噌二就テ, 唒酵過程

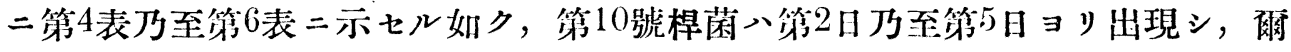
後ハ經過日數二正比例シテ增加シ，逐二八全然無數トナレリ，而シテ攸ホ本菻

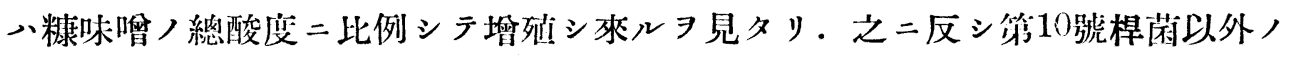
21 株》，既製糠味嗊卜同樣二出現狀况一定セズ．但シ調製日淺キモノ八，之ヨ 成熟セルモノ二比シテ一般二發生菌數多數ナルヨ認ム.

\section{第 3 章 槺味噲ヨコ分離セル措菌ノ性狀 \\ 第 1 節 分離諸菌ノ顯微鏡的檢查所 \\ 見二就テ}

以上余ガ糠味嚊ヨリ分離培養セル 22 菌株二就テ夫々塗抹標本 7 製シ, 先ヅす にりん色素ヨ以テ染色シ形態及ビ夫サ 法二對スル態度 $ヨ$ 檢シ，特二桿菌 13 株二就テハ夫々今井，日高氏法ニョリテ鞭 毛染色法习施シ，更二こーんりっひ・わいつまん氏法ニョリテ芽胞染色法妇施 シ檢查セリ。其ノ成績八第 7 表ノ如シ.

\section{第 7 表}

\begin{tabular}{|c|c|c|c|c|c|c|c|c|}
\hline & \multirow{2}{*}{ 形 } & \multicolumn{2}{|c|}{ 菌ノ大サ } & \multicolumn{2}{|c|}{ (單位 $\mu$ ) } & \multirow{2}{*}{$\begin{array}{l}\text { ぐらも染 } \\
\text { 色二齗 } \\
\text { 儿態废 }\end{array}$} & \multirow{2}{*}{$\begin{array}{l}\text { 鞭 毛 } \\
\text { 行 }\end{array}$} & \multirow{2}{*}{$\begin{array}{l}\text { 芽胞 } \\
\text { 何 }\end{array}$} \\
\hline 菌 & & 橫 & 徑 & 縱 & 徑 & & & \\
\hline 1 & 球菌 & \multicolumn{4}{|c|}{0.6} & + & & \\
\hline 2 & "I & \multicolumn{4}{|c|}{0.7} & + & & \\
\hline 3 & "I & \multicolumn{4}{|c|}{$0.6-0.7$} & + & & \\
\hline 4 & "I & \multicolumn{4}{|c|}{$0.7-0.8$} & + & & \\
\hline 5 & "I & \multicolumn{4}{|c|}{0.8} & + & & \\
\hline
\end{tabular}




\begin{tabular}{|c|c|c|c|c|c|c|}
\hline \multirow{2}{*}{ 得 } & \multirow{2}{*}{ 形 } & 菌八大サ & (單位 $\mu$ ) & \multirow{2}{*}{ 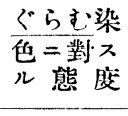 } & \multirow{2}{*}{$\begin{array}{l}\text { 鞭 毛 } \\
\text { 在 }\end{array}$} & \multirow{2}{*}{$\begin{array}{l}\text { 芽胞 } \\
\text { 無 }\end{array}$} \\
\hline & & 槛 嘼 & 縱 徑 & & & \\
\hline 6 & 球菌 & \multicolumn{2}{|c|}{0.6} & + & & \\
\hline 7 & "I & \multicolumn{2}{|c|}{1.2} & + & & \\
\hline 8 & 雙球药 & \multicolumn{2}{|c|}{$0.7-0.8$} & + & & \\
\hline 9 & 四聯球菌 & \multicolumn{2}{|c|}{0.8} & + & & \\
\hline 10 & 椙苻 & 0.7 & 1.4 & + & - & - \\
\hline 11 & " & 0.4 & $0.7-2.0$ & - & + & - \\
\hline 12 & " & 0.6 & $0.7-1.4$ & - & + & - \\
\hline 13 & " & 0.7 & $2.1-7.0$ & - & + & - \\
\hline 14 & " & 1.2 & $0.8-3.0$ & - & + & - \\
\hline 15 & " & 0.8 & $1.4-2 . \mathrm{i}$ & - & + & - \\
\hline 16 & " & 0.4 & $1.4-1.8$ & - & + & - \\
\hline 17 & " & 0.7 & 2.0 & + & + & + \\
\hline 18 & " & 1.1 & 2.8 & + & + & + \\
\hline 19 & " & 1.0 & $2.1-3.5$ & + & + & + \\
\hline 20 & " & $\cdot 1.0$ & $1.5-2.8$ & + & + & + \\
\hline 21 & " & 0.6 & $2.1-3.0$ & + & + & + \\
\hline 22 & " & 0.7 & $1.4--2.0$ & + & + & + \\
\hline
\end{tabular}

即于第 7 表二示スガ如ク球菌ハ絗テぐらむ陽性ニシテ, 內各 1 株ノ雙球菌及 ビ四聯球菌ヨ混ズ，又桿菌ノ內ぐらむ除性ノモノ 6 株，〈゙らむ陽性ノモノ7 株 算シ, 即于合計 13 株ノ桿菌中, 第 10 號菌ノ他入總亏鞭毛 7 證明シ, 陽性桿菌 八内 6 株八芽胞 $\exists$ 有ス.

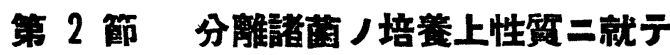

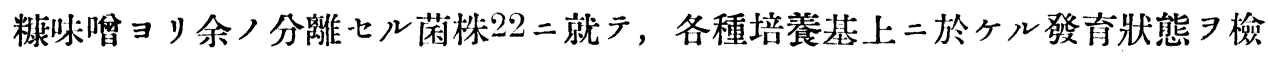
查シ,一括表示スレバ笴 8 表ノ如シ.

第 8 表 


\begin{tabular}{|c|c|c|c|c|c|c|}
\hline 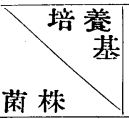 & $\begin{array}{l}\text { 普 通 寒 } \\
\text { 斜 面 }\end{array}$ & 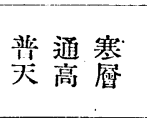 & 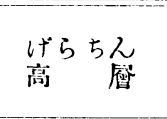 & ぶよん & 䒘ふ心 & 婜鉿葱 \\
\hline 1 & 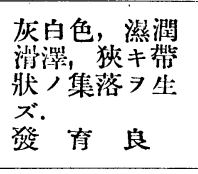 & 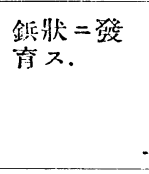 & $\begin{array}{l}\text { 上部保=液 } \\
\text { 化:，荫沒 } \\
\text { ス。 }\end{array}$ & 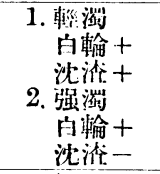 & 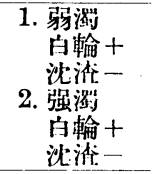 & $\begin{array}{l}\text { 庆白色, 菲 } \\
\text { 溥, 阐荅 } \\
\text { 生ズ. }\end{array}$ \\
\hline 2 & 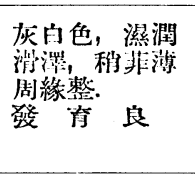 & 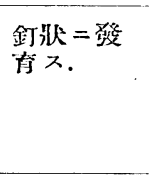 & 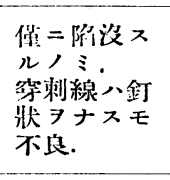 & 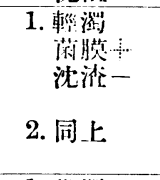 & 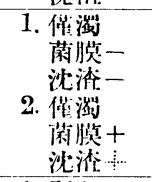 & 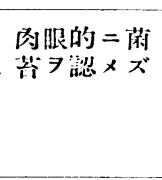 \\
\hline 3 & 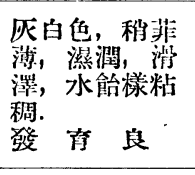 & $\begin{array}{l}\text { 釗狀=發 } \\
\text { 青 } 。 . ~\end{array}$ & $\begin{array}{l}\text { 上部約 } 4 \text { 分 } \\
\text { １．液化 } \\
\text { ス. }\end{array}$ & $\begin{array}{l}\text { 1. 垈罚 } \\
\text { 荫脱- } \\
\text { 沈浩- } \\
\text { 2. 同上 }\end{array}$ & 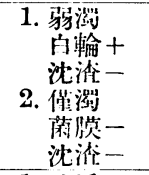 & 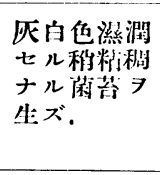 \\
\hline 4 & 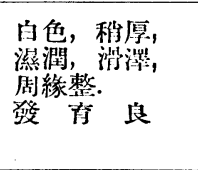 & $\begin{array}{l}\text { 牷狀=發 } \\
\text { 青ス。. }\end{array}$ & 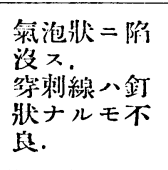 & 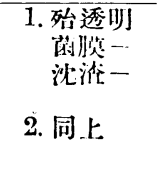 & 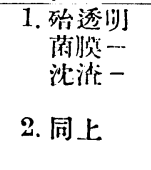 & 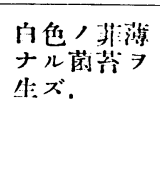 \\
\hline 5 & 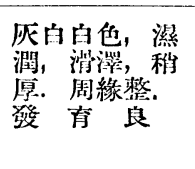 & 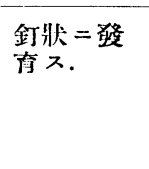 & $\begin{array}{l}\text { 1. 部 } 4 \text { 分 } \\
1 \text { 八液化 }\end{array}$ & 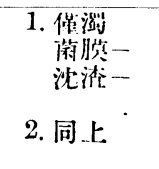 & 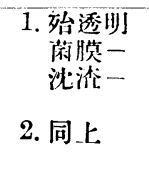 & 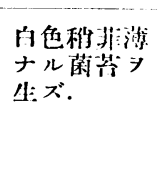 \\
\hline 6 & 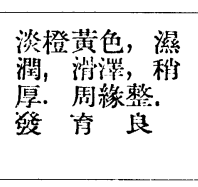 & $\begin{array}{l}\text { 毛篗狀= } \\
\text { 發青 }\end{array}$ & 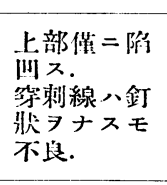 & 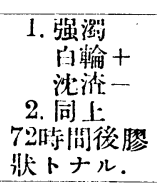 & $\begin{array}{l}\text { 1. 强灌 } \\
\text { 箚 }+ \\
\text { 沈楛- } \\
\text { 2. 同上 }\end{array}$ & 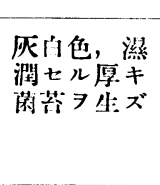 \\
\hline 7 & 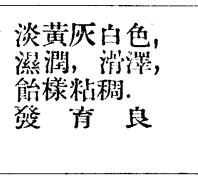 & $\begin{array}{l}\text { 線狀 }=\text { 發 } \\
\text { 䏍入. }\end{array}$ & 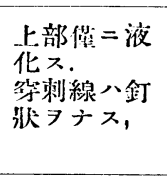 & 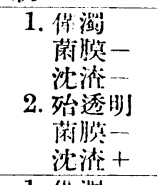 & 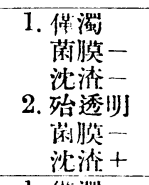 & 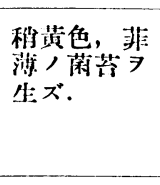 \\
\hline 8 & 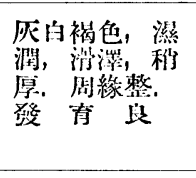 & $\begin{array}{l}\text { 金状=碚 } \\
\text { 侖. }\end{array}$ & 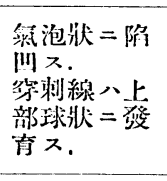 & 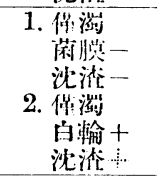 & 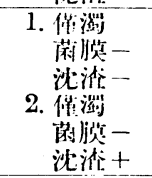 & 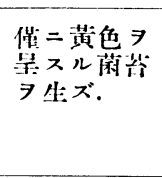 \\
\hline 9 & 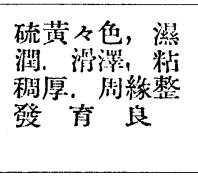 & 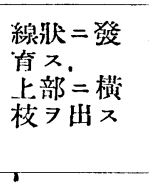 & 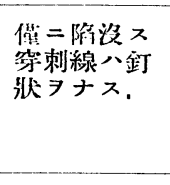 & 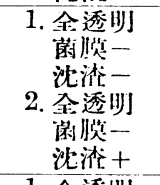 & 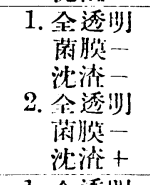 & 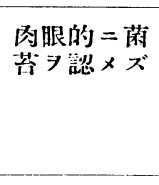 \\
\hline 10 & $\begin{array}{l}\text { 淡灰白色, 透 } \\
\text { 明孤立性,微 } \\
\text { 紻ナ儿集落. } \\
\text { 發青不良 }\end{array}$ & $\begin{array}{l}\text { 線狀 }=\text { 發 } \\
\text { 有ス. }\end{array}$ & 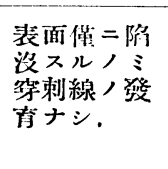 & 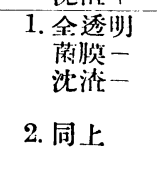 & 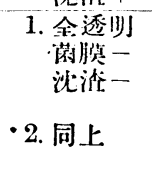 & $\begin{array}{l}\text { 肉哏的二莉 } \\
\text { 苦 } 7 \text { 認メズ }\end{array}$ \\
\hline
\end{tabular}




訨庭古雄述

\begin{tabular}{|c|c|c|c|c|c|c|c|c|c|}
\hline 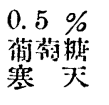 & $\begin{array}{l}0.5 \% \\
\text { 孚倄 } \\
\text { 寒 }\end{array}$ & $\begin{array}{l}\text { のいミら } \\
\text { ーえろー } \\
\text { ミ寒天 }\end{array}$ & 牛等 & $\begin{array}{c}\text { らくさす } \\
\text { 乳 } \\
\text { 清 }\end{array}$ & 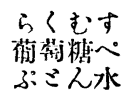 & 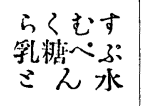 & $\begin{array}{l}\text { 血液 } \\
\text { 寒天 }\end{array}$ & 遠藤 & いんご \\
\hline $\begin{array}{l}\text { 釷 获 } \\
\text { 秘不良 }\end{array}$ & $\begin{array}{l}\text { 涂 羿 } \\
\text { 秒不良 }\end{array}$ & $\begin{array}{l}\text { 變化ナ } \\
\text { 严 }\end{array}$ & $\begin{array}{l}\text { 1. 不變 } \\
\text { 2. 不變 }\end{array}$ & $\begin{array}{l}\text { 1. 紫洼 } \\
\text { 2. 青 } \\
\text { 3. 郝 }\end{array}$ & $\begin{array}{l}\text { 1. 紫 } \\
\text { 2. 紫黃 } \\
\text { 3. 紫黃 }\end{array}$ & $\begin{array}{l}\text { 1. 紫 } \\
\text { 2. 青紫 } \\
\text { 3. 青紫 }\end{array}$ & 不溶 & 不變 & - \\
\hline $\begin{array}{l}\text { 领 狀 } \\
\text { 稍不良 }\end{array}$ & $\begin{array}{l}\text { 㤠ド裂 } \\
\text { 会 }\end{array}$ & $\begin{array}{l}\text { 戀化ナ } \\
\dot{\Sigma}\end{array}$ & $\begin{array}{l}\text { 1. 不變 } \\
\text { 2. 不彎 }\end{array}$ & $\begin{array}{l}\text { 1. 紫 } \\
\text { 2. 紫青 } \\
\text { 3. 紫青 }\end{array}$ & $\begin{array}{l}\text { 1. 紫 } \\
\text { 2. 紫青 } \\
\text { 3. 毒 }\end{array}$ & $\begin{array}{l}\text { 1. 紫 } \\
\text { 2. 紫毒 } \\
\text { 3. 紫 }\end{array}$ & 不溶 & 不變 & - \\
\hline $\begin{array}{l}\text { 金桀 } \\
\text { 良 }\end{array}$ & $\begin{array}{l}\text { 金 牀 } \\
\text { 良 }\end{array}$ & $\begin{array}{l}\text { 戀化ナ } \\
\text { 至 }\end{array}$ & $\begin{array}{l}\text { 1. 不變 } \\
\text { 2. 不變 }\end{array}$ & $\begin{array}{l}\text { 1. 紫 } \\
\text { 2. 紫清 } \\
\text { 3. 紫清 }\end{array}$ & $\begin{array}{l}\text { 1: 紫 } \\
\text { 2. 紫 } \\
\text { 3. 紫 }\end{array}$ & $\begin{array}{l}\text { 1. 紫 } \\
\text { 2. 紫 } \\
\text { 3. 紫 }\end{array}$ & 不溶 & 不戀 & - \\
\hline 食汱 & 鎬 爿 & $\begin{array}{l}\text { 變化ナ } \\
\text { シ }\end{array}$ & 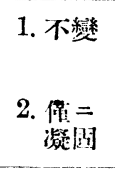 & $\begin{array}{l}\text { 1. 赫紫 } \\
\text { 2. 赫紫 } \\
\text { 3. 赫紫 }\end{array}$ & $\begin{array}{l}\text { 1. 紫亦 } \\
\text { 2. 赤紫 } \\
\text { 3. 赤 }\end{array}$ & $\begin{array}{l}\text { 1. 紫 } \\
\text { 2. 紫 } \\
\text { 3. 赫紫 }\end{array}$ & 不溶 & $\begin{array}{l}24 \text { 時間 } \\
\text { 後=亦 } \\
\text { 戀入. }\end{array}$ & - \\
\hline 金 爿 & 金 跃 & 戀化ナ & $\begin{array}{l}\text { 1. 不變 } \\
\text { 2. 不變 }\end{array}$ & $\begin{array}{l}\text { 1. 紫清 } \\
\text { 2. 紫 } \\
\text { 3. 紫赤 }\end{array}$ & $\begin{array}{l}\text { 1. 紫赤 } \\
2 . \text { 赤 } \\
3 \text {. 赤 }\end{array}$ & $\begin{array}{l}\text { 1. 紫 } \\
\text { 2. 赤 } \\
\text { 3. 赫 }\end{array}$ & 僅溶 & 不變 & - \\
\hline $\begin{array}{l}\text { 線状 } \\
\text { 种不践 }\end{array}$ & $\begin{array}{l}\text { 線 牀 } \\
\text { 点 }\end{array}$ & $\begin{array}{l}\text { 戀化ナ } \\
\text { 严 }\end{array}$ & $\begin{array}{l}\text { 1. 不變 } \\
\text { 2. 凝洞 }\end{array}$ & $\begin{array}{l}\text { 1. 紫 } \\
\text { 2. 读 } \\
\text { 3. 䑙 }\end{array}$ & $\begin{array}{l}\text { 1. 紫 } \\
\text { 2. 紫㤽 } \\
\text { 3. 紫黄 }\end{array}$ & $\begin{array}{l}\text { 1. 紫 } \\
\text { 2. 紫青 } \\
\text { 3. 青 }\end{array}$ & 不溶 & 不變 & - \\
\hline 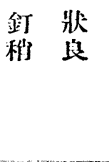 & 全 祆 & $\begin{array}{l}\text { 戀化ナ } \\
\dot{\Sigma}\end{array}$ & 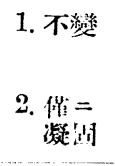 & $\begin{array}{l}\text { 1. 紫 } \\
\text { 2. 紫 } \\
\text { 3. 紫 }\end{array}$ & $\begin{array}{l}\text { 1. 紫 } \\
\text { 2. 紫 } \\
\text { 3. 紫 }\end{array}$ & $\begin{array}{l}\text { 1. 紫 } \\
\text { 2. 紫 } \\
\text { 3. 紫 }\end{array}$ & 不溶 & 不變 & - \\
\hline 金 哭 & 金 状 & 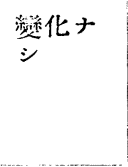 & $\begin{array}{l}\text { 1. 不變 } \\
\text { 2. 不變 }\end{array}$ & $\begin{array}{l}\text { 1. 紫 } \\
\text { 2. 紫办 } \\
\text { 3. 紫办 }\end{array}$ & $\begin{array}{l}\text { 1. 赤 } \\
\text { 2. 赫 } \\
\text { 3. 赫 }\end{array}$ & $\begin{array}{l}\text { 1. 紫 } \\
\text { 2. 紫 } \\
\text { 3. 紫 }\end{array}$ & 不溶 & 不變 & - \\
\hline $\begin{array}{l}\text { 苓 狀 } \\
\text { 稍不良 }\end{array}$ & $\begin{array}{ll}\text { 金 } & \text { 狀 } \\
\text { 良 }\end{array}$ & $\begin{array}{l}\text { 變化ナ } \\
\text { シ }\end{array}$ & $\begin{array}{l}\text { 1. 不變 } \\
\text { 2. 不變 }\end{array}$ & $\begin{array}{l}\text { 1. 紫 } \\
\text { 2. 紫清 } \\
\text { 3. 紫清 }\end{array}$ & $\begin{array}{l}\text { 1. 紫 } \\
\text { 2. 紫燕 } \\
\text { 3. 紫毒 }\end{array}$ & $\begin{array}{l}\text { 1. 紫 } \\
\text { 2. 紫青 } \\
\text { 3. 毒 }\end{array}$ & 不溶 & 不變 & - \\
\hline $\begin{array}{l}\text { 線 脶 } \\
\text { 甚 }\end{array}$ & $\begin{array}{l}\text { 線 茯 } \\
\text { 甚 }\end{array}$ & 戀化ナ & $\begin{array}{l}\text { 1. 不變 } \\
\text { 2. 不繂 }\end{array}$ & $\begin{array}{l}\text { 1. 赫 } \\
\text { 2. 赤柴 } \\
\text { 3. 亦少 } \\
\text { 紫 }\end{array}$ & $\begin{array}{l}\text { 1. 赫 } \\
\text { 2. 赤 } \\
\text { 3. 亦 }\end{array}$ & $\begin{array}{l}\text { 1. 紫 } \\
2 . \text { 赤 } \\
\text { 3. 赤 }\end{array}$ & 不溶 & 不變 & - \\
\hline
\end{tabular}




\begin{tabular}{|c|c|c|c|c|c|c|}
\hline 基 & $\begin{array}{l}\text { 普 通 寒 } \\
\text { 斜 面 }\end{array}$ & $\begin{array}{l}\text { 普通寒 } \\
\text { 愿 }\end{array}$ & げらちん & ふいよん & $\hat{2}$ 主水 & 㸞 鈴 薯 \\
\hline 11 & 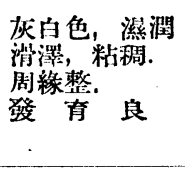 & 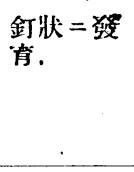 & $\begin{array}{l}\text { 僅二裴面陷 } \\
\text { 沟 } .\end{array}$ & 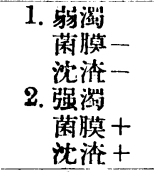 & 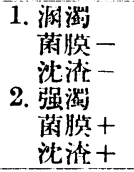 & $\begin{array}{l}\text { 秒兴色／灰 } \\
\text { 自菌苔 } \\
\text { 生ス。. }\end{array}$ \\
\hline 12 & 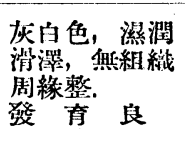 & 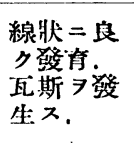 & 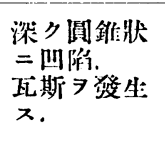 & $\begin{array}{l}\text { 1. 殆透四 } \\
\text { 白榆十 } \\
\text { 沈淮 - } \\
\text { 2. 同上 }\end{array}$ & 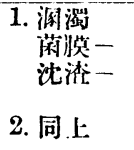 & $\begin{array}{l}\text { 炏门色, 菲 } \\
\text { 䍜人集落 } \\
\text { 生ズ. }\end{array}$ \\
\hline 13 & 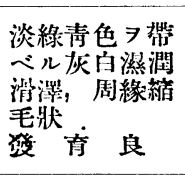 & $\begin{array}{ll}\text { 鎬 } & \text { 狀 } \\
\text { 稍 } & \text { 良 }\end{array}$ & $\begin{array}{l}\text { 㮖=陥沟 } \\
\text { ル }\end{array}$ & 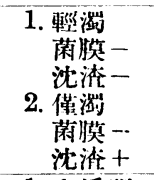 & 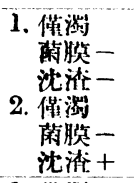 & 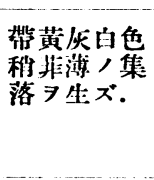 \\
\hline 14 & 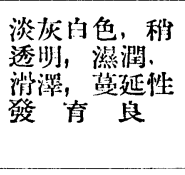 & $\begin{array}{l}\text { 線状=發 } \\
\text { 亩. }\end{array}$ & $\begin{array}{l}\text { 上部 } 4 \text { 分， } \\
1 \text { 八液化 }\end{array}$ & 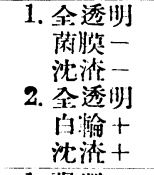 & 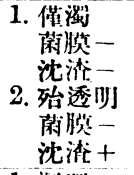 & 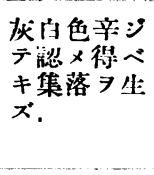 \\
\hline 15 & $\begin{array}{l}\text { 灰白色，濕澗 } \\
\text { 翡溥，盗延性 } \\
\text { 發有 }\end{array}$ & $\begin{array}{ll}\text { 金 狀 } \\
\text { 不 良 }\end{array}$ & $\begin{array}{l}\text { 㮖二附没ス } \\
\text { 势刺線八釘 } \\
\text { 狀. }\end{array}$ & 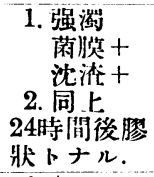 & 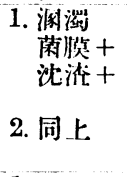 & $\begin{array}{l}\text { 庆白色活 } \\
\text { キ厚集溚 } \\
\text { 生ズ. }\end{array}$ \\
\hline 16 & 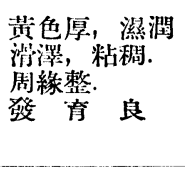 & $\begin{array}{l}\text { 線 狀 } \\
\text { 良 }\end{array}$ & 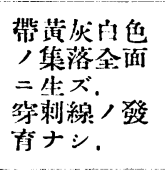 & 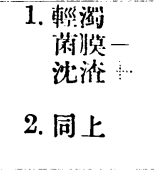 & 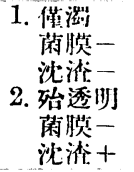 & $\begin{array}{c}\text { 内色，科溥 } \\
\text { キ集落 } \\
\text { ズ. }\end{array}$ \\
\hline 17 & 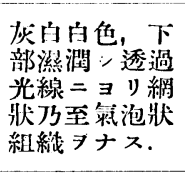 & $\begin{array}{l}\text { 線 狀 } \\
\text { 良 } \\
\text { 瓦斯發生: }\end{array}$ & $\begin{array}{l}\text { 上部 } コ \text { リ約 } \\
2 \text { 分, } 1 \text { 八液 } \\
\text { 化ス. }\end{array}$ & 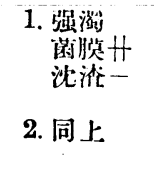 & 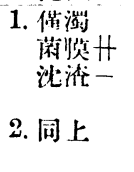 & 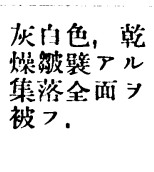 \\
\hline 18 & 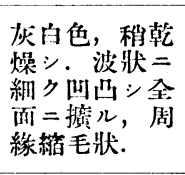 & $\begin{array}{l}\text { 線状, 上. } \\
\text { 部二狗毛 } \\
\text { 樣玟 } \Rightarrow \text { 出 } \\
\text { ス. }\end{array}$ & 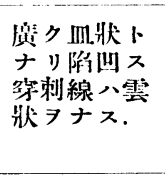 & 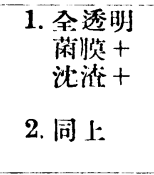 & 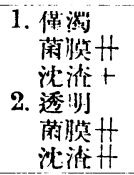 & $\begin{array}{l}\text { 灰的白色， } \\
\text { 厚キ集洛全 } \\
\text { 面 } \text { 被フ. }\end{array}$ \\
\hline 19 & 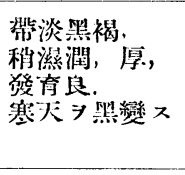 & $\begin{array}{l}\text { 線 狀 } \\
\text { 良 }\end{array}$ & 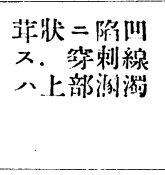 & 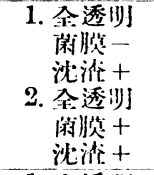 & 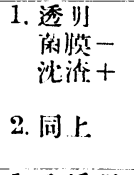 & 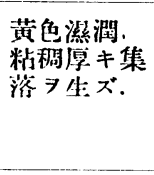 \\
\hline 20 & 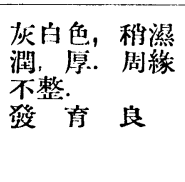 & $\begin{array}{l}\text { 金 爿 } \\
\text { 良 }\end{array}$ & $\begin{array}{l}\text { 深 ク何錐狀 } \\
=\text { =陷凹 } 2 .\end{array}$ & 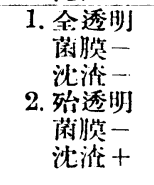 & 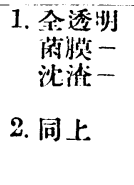 & $\begin{array}{l}\text { 僅二集白色 } \\
\text { 集淥 } \\
\text { ズ. }\end{array}$ \\
\hline
\end{tabular}


伊还吉雄

(1479)

\begin{tabular}{|c|c|c|c|c|c|c|c|c|c|}
\hline 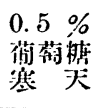 & $\begin{array}{l}0.5 \% \\
\text { 孚 糗 } \\
\text { 基 关 }\end{array}$ & 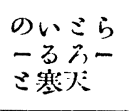 & 保乳 & 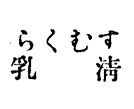 & 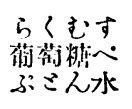 & 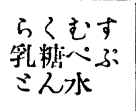 & $\begin{array}{l}\text { 血液 } \\
\text { 寒天 }\end{array}$ & 遠藤 & いんご \\
\hline $\begin{array}{l}\text { 線 状 } \\
\text { 采 } \\
\text { 互斯發 } \\
\text { 生 }\end{array}$ & $\begin{array}{l}\text { 線 狀 } \\
\text { 良 } \\
\text { 互斯發 } \\
\text { 生 }\end{array}$ & $\begin{array}{l}\text { 管光, } \\
\text { 正斯莜 } \\
\text { 尘: }\end{array}$ & $\begin{array}{l}\text { 1. 不變 } \\
\text { 2. 不變 }\end{array}$ & $\begin{array}{l}\text { 1. 亦 } \\
\text { 2. 洂紫 } \\
\text { 3. 青 }\end{array}$ & $\begin{array}{l}\text { 1. 告黄 } \\
\text { 2. 尔黄 } \\
\text { 3. 尔 }\end{array}$ & $\begin{array}{l}\text { 1. 紫 } \\
\text { 2. 紫黄 } \\
\text { 3. 紫黃 }\end{array}$ & 不溶 & 赤變 & - \\
\hline $\begin{array}{l}\text { 線 狀 } \\
\text { 良 } \\
\text { 斯䋁 } \\
\text { 生: }\end{array}$ & $\begin{array}{l}\text { 線 狀 } \\
\text { 良 } \\
\text { 互斯倠 } \\
\text { 尘 }\end{array}$ & 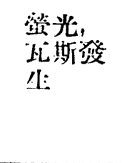 & $\begin{array}{c}\text { 1. 不變 } \\
\text { 2. 穛强 } \\
\text { ク㠜 } \\
\text { 回 }\end{array}$ & $\begin{array}{l}\text { 1. 尔 } \\
\text { 2. 部 } \\
\text { 3. 少 }\end{array}$ & $\begin{array}{l}\text { 1. 赫黃 } \\
\text { 2. 赫紫 } \\
\text { 3. 柴 }\end{array}$ & $\begin{array}{l}\text { 1. 紫 } \\
\text { 2. 紫黃 } \\
\text { 3. 紫黃 }\end{array}$ & 不溶 & 不變 & + \\
\hline 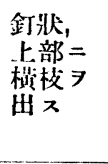 & $\begin{array}{l}\text { 線状, } \\
\text { 上部= } \\
\text { 顺毛状 } \\
\text { 枝习出 } \\
\text { ス }\end{array}$ & 變化ナ & $\begin{array}{l}\text { 1. 不變 } \\
\text { 2. 不戀 }\end{array}$ & $\begin{array}{l}\text { 1. 紫 } \\
\text { 2. 紫靑 } \\
\text { 3. 紫毒 }\end{array}$ & $\begin{array}{l}\text { 1. 柴 } \\
\text { 2. 紫青 } \\
\text { 3. 毒 }\end{array}$ & $\begin{array}{l}\text { 1. 紫 } \\
\text { 2. 紫毒 } \\
\text { 3. 青 }\end{array}$ & 不溶 & 不變 & - \\
\hline $\begin{array}{l}\text { 金弲 } \\
\text { 良 }\end{array}$ & $\begin{array}{l}\text { 線 状 } \\
\text { 不 }\end{array}$ & $\begin{array}{l}\text { 變化ナ } \\
\text { シ }\end{array}$ & $\begin{array}{l}\text { 1. 不變 } \\
\text { 2. 殆ド } \\
\text { 液化 }\end{array}$ & $\begin{array}{l}\text { 1. 紫 } \\
\text { 2. 紫毒 } \\
\text { 3. 青紫 }\end{array}$ & $\begin{array}{l}\text { 1. 紫 } \\
\text { 2. 聲紫 } \\
\text { 3. 毒 }\end{array}$ & $\begin{array}{l}\text { 1. 紫 } \\
\text { 2. 紫 } \\
\text { 3. 紫靑 }\end{array}$ & 不溶 & 不變 & - \\
\hline $\begin{array}{l}\text { 線 爿 } \\
\text { 不 良 }\end{array}$ & $\begin{array}{l}\text { 線 紎 } \\
\text { 良 }\end{array}$ & 變化ナ & $\begin{array}{l}\text { 1. 不變 } \\
\text { 2. 凝固 }\end{array}$ & $\begin{array}{l}\text { 1. 紫 } \\
\text { 2. 紫毒 } \\
\text { 3. 青紫 }\end{array}$ & $\begin{array}{l}\text { 1. 紫 } \\
\text { 2. 青紫 } \\
\text { 3. 青 }\end{array}$ & $\begin{array}{l}\text { 1. 紫 } \\
\text { 2. 紫. } \\
\text { 3. 紫青 }\end{array}$ & 不溶 & 不變 & - \\
\hline $\begin{array}{l}\text { 線 爿 } \\
\text { 良 }\end{array}$ & $\begin{array}{l}\text { 唋 狀 } \\
\text { 良 }\end{array}$ & 變化ナ & $\begin{array}{l}\text { 1. 不變 } \\
\text { 2. 不變 }\end{array}$ & $\begin{array}{l}\text { 1. 紫 } \\
\text { 2. 紫 } \\
\text { 3. 紫 }\end{array}$ & $\begin{array}{l}\text { 1. 紫 } \\
\text { 2. 紫 } \\
\text { 3. 紫 }\end{array}$ & $\begin{array}{l}\text { 1. 紫 } \\
\text { 2. 青紫 } \\
\text { 3. 青 }\end{array}$ & 不溶 & 不變 & - \\
\hline $\begin{array}{l}\text { 線 状 } \\
\text { 良 } \\
\text { 正斯發 } \\
\text { 生 }\end{array}$ & $\begin{array}{l}\text { 線状 } \\
\text { 揹良, } \\
\text { 桼斯㹣 } \\
\text { 生. }\end{array}$ & 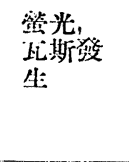 & $\begin{array}{l}\text { 1. 不變 } \\
\text { 3. 强ク } \\
\text { 㠜圆 }\end{array}$ & $\begin{array}{l}\text { 1. 尔蓝 } \\
2 \text { 尔 } \\
\text { 3. 尔 }\end{array}$ & $\begin{array}{l}\text { 1. 尔 } \\
\text { 2. 尔 } \\
\text { 3. 尔 }\end{array}$ & $\begin{array}{l}\text { 1. 赤 } \\
\text { 2. 赤紫 } \\
\text { 3. 紫黃 }\end{array}$ & 不溶 & 不戀 & - \\
\hline $\begin{array}{l}\text { 線 状 } \\
\text { 食 }\end{array}$ & $\begin{array}{l}\text { 線 状 } \\
\text { 良 }\end{array}$ & 戀化ナ & $\begin{array}{c}\text { 1. 秒强 } \\
\text { ク液 } \\
\text { 化 } \\
\text { 2. 全” } \\
\text { 液化 }\end{array}$ & $\begin{array}{l}\text { 1. 紫亦 } \\
\text { 2. 紫紧 } \\
\text { 3. 毒紫 }\end{array}$ & $\begin{array}{l}\text { 1. 紫 } \\
\text { 2. 異 } \\
\text { 3. 黃 }\end{array}$ & $\begin{array}{l}\text { 1. 紫 } \\
\text { 2. 紫黄 } \\
\text { 3. 紫毒 }\end{array}$ & 不溶 & 不變 & - \\
\hline $\begin{array}{l}\text { 線 桨 } \\
\text { 不 食 }\end{array}$ & $\begin{array}{l}\text { 釗 狀 } \\
\text { 稍 良 }\end{array}$ & 継化ナ & $\begin{array}{c}\text { 1. 不變 } \\
\text { 2. 秒强 } \\
\text { ク液 } \\
\text { 化 }\end{array}$ & $\begin{array}{l}\text { 1. 赫紫 } \\
\text { 2. 尔紫 } \\
\text { 3. 亦办 } \\
\text { 紫 }\end{array}$ & $\begin{array}{l}\text { 1. 紫赤 } \\
\text { 2. 亦紫 } \\
\text { 3. 尔 }\end{array}$ & $\begin{array}{l}\text { 1. 紫赤 } \\
\text { 2. 紫 } \\
\text { 3. 紫赤 }\end{array}$ & 不溶 & 不變 & - \\
\hline $\begin{array}{l}\text { 釘 祆 } \\
\text { 科 良 }\end{array}$ & $\begin{array}{l}\text { 線 犾 } \\
\text { 稍 良 }\end{array}$ & 戀化ナ & $\begin{array}{l}\text { 1. 不巒 } \\
\text { 2. 保 }= \\
\text { 液化 }\end{array}$ & $\begin{array}{l}\text { 1. 紫 } \\
\text { 2. 紫承 } \\
\text { 3. 紫办 }\end{array}$ & $\begin{array}{l}\text { 1. 紫 } \\
\text { 2. 紫赤 } \\
\text { 3. 紫尔 }\end{array}$ & $\begin{array}{l}\text { 1. 紫 } \\
\text { 2. 紫赤 } \\
\text { 3. 紫告 }\end{array}$ & 不溶 & 不變 & - \\
\hline
\end{tabular}




\begin{tabular}{|c|c|c|c|c|c|c|}
\hline $\begin{array}{r}\text { 堷 盖 } \\
\text { 基 }\end{array}$ & $\begin{array}{l}\text { 普通褰 } \\
\text { 面 }\end{array}$ & 並通寒 & $\begin{array}{l}\text { げらちん } \\
\text { 高 層 }\end{array}$ & ふいよん & $\widetilde{2} 3 \stackrel{\Xi}{\text { 水 }}$ & 哭 鈴 薯 \\
\hline 21 & 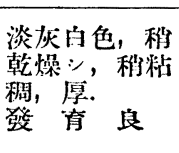 & $\begin{array}{ll}\text { 金 狀 } \\
\text { 良 }\end{array}$ & $\begin{array}{l}\text { 上部約 } 4 \text { 分 } \\
\text { ス } \text { 八液化 }\end{array}$ & 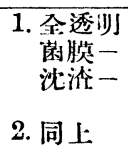 & $\begin{array}{l}\text { 1. 全透四 } \\
\text { 荇鉴- } \\
\text { 沈注- } \\
\text { 2. 同上 }\end{array}$ & 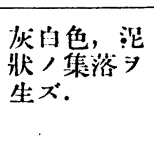 \\
\hline 22 & 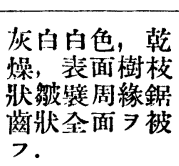 & 釘狀發有 & $\begin{array}{l}\text { 上部 } 4 \text { 分， } \\
1 \text { 八液化 }\end{array}$ & 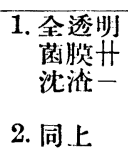 & 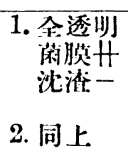 & 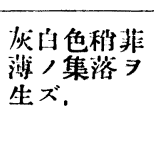 \\
\hline
\end{tabular}

\section{備 考}

1.ぶよん，へぷさん水培盖基八（1）24日寺間，(2) 72 時間，成絽.

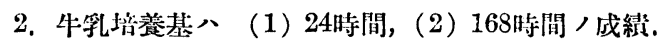

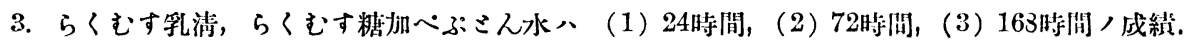

4. いんジーる反應八, へぶん水72時间培盖ノモ/

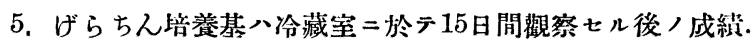

即チ分離菌株ノ各種染色ニョル鏡檢上ノ所見ト各種培養基ニ於ケル培養性狀 ト 照合シ制定 ハ橙色葡萄狀球菌，第 7 號菌ハ黄色葡萄狀球菌ナルベク，第 8 號菌ハ灰白色隻 球菌, 第 9 號菌、㣴色四聯球菌タルコト明カナリ。㕛第 10 號菌、糠味骝ノ乳酸 睽酵ノ本態菌タル 1 種ノ乳酸菌二類似スル桿菌ニシテ，符 11 及ビ第 12 號菌、大 腸菌，第 13 及ビ第 16 號菌、綠膿菌，第 14 及ビ第 15 號菌、普通變形菌，第 17 乃至 第 19 號菌、騟鈴薯菌，第 20 及ビ第 21 號菌、枯草菌，第 22 號菌、根狀菌タルタ知 ルベシ.

\section{第 3 節 分蜼諸菌ノ熱二對スル抵抗二 就テ}

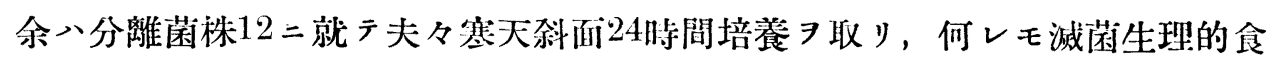
監水 $\ni$ 以テ $1.0 \mathrm{mg}$ 對 $1.0 \mathrm{cc}$ ノ比 $\ni$ 以テ菌浮游液二製 シ, 夫々 $50^{\circ} \mathrm{C}, 60^{\circ} \mathrm{C}, 70^{\circ} \mathrm{C}$, $90^{\circ} \mathrm{C}, 100^{\circ} \mathrm{C}$ /重漟煎內二保于, 5 分, 10 分, 15 分, 30 分, 1 時間卜夫夕時間 7 劃シテ 1 白金耳量 7 釣取シ, 基天斜面二移植 $\exists$ 行ヒ, 集落發生ノ有無 $\exists$ 檢査制 


$$
\text { 伊庭吉雄述 }
$$

\begin{tabular}{|c|c|c|c|c|c|c|c|c|c|}
\hline 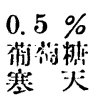 & $\begin{array}{l}0.5 \% \\
\text { 乳 菻 } \\
\text { 基 }\end{array}$ & $\begin{array}{l}\text { のマら } \\
\text { 一るろー } \\
\text { こ寒天 }\end{array}$ & 牛乳 & $\begin{array}{l}\text { らくをす } \\
\text { 乳 }\end{array}$ & 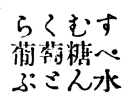 & 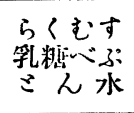 & $\begin{array}{l}\text { 血液 } \\
\text { 寒天 }\end{array}$ & 逊藤 & いんご \\
\hline $\begin{array}{l}\text { 線 状 } \\
\text { 稍不良 }\end{array}$ & 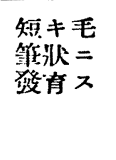 & 戀化ナ & $\begin{array}{l}\text { 1. 不變 } \\
\text { 2. 不變 }\end{array}$ & $\begin{array}{l}\text { 1. 紫 } \\
\text { 2. 紫 } \\
\text { 3. 紫 }\end{array}$ & $\begin{array}{l}\text { 1. 紫步 } \\
\text { 2. 赫 } \\
\text { 3. 赫紫 }\end{array}$ & $\begin{array}{l}\text { 1. 紫 } \\
\text { 2. 紫 } \\
\text { 3. 紫青 }\end{array}$ & 不溶 & 不變 & - \\
\hline 金 汱 & $\begin{array}{l}\text { 留 良 } \\
\text { 良 }\end{array}$ & 戀化ナ & $\begin{array}{l}\text { 1. 不變 } \\
\text { 2. 鞒 }= \\
\text { 液化 }\end{array}$ & $\begin{array}{l}\text { 1. 紫 } \\
\text { 2. 紫静 } \\
\text { 3. 紫静 }\end{array}$ & $\begin{array}{l}\text { 1. 紫 } \\
\text { 2. 紫青 } \\
\text { 3. 青紫 }\end{array}$ & $\begin{array}{l}\text { 1. 紫 } \\
\text { 2. 紫 } \\
\text { 3. 紫黄 }\end{array}$ & 溶血 & 不變 & - \\
\hline
\end{tabular}

定セリ. 其ノ成績ハ第 9 表ノ如シ.

第 9 表

\begin{tabular}{|c|c|c|c|c|c|c|}
\hline 菌種 & 作用洔间 & $5^{\prime}$ & $10^{\prime}$ & $15^{\prime}$ & $30^{\prime}$ & $6 J^{\prime}$ \\
\hline \multirow{2}{*}{$\begin{array}{l}\text { 白色葴瀻 } \\
\text { 状球 菌 }\end{array}$} & $50^{\circ} \mathrm{C}$ & $H$ & + & + & - & - \\
\hline & $60 "$ & - & - & - & - & - \\
\hline \multirow{2}{*}{$\begin{array}{l}\text { 橙色蒲葡 } \\
\text { 鼎球菌 }\end{array}$} & $50 "$ & $H$ & H & H & $H$ & + \\
\hline & 60 & $H$ & $H$ & $H$ & + & - \\
\hline \multirow{2}{*}{ 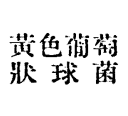 } & $50 " 1$ & + & - & - & - & - \\
\hline & $60 "$ & - & - & - & - & - \\
\hline \multirow{2}{*}{$\begin{array}{l}\text { 灰泉色 } \\
\text { 雙球落 }\end{array}$} & $50 " 1$ & H & H & $H$ & + & + \\
\hline & $60 "$ & $H$ & $H$ & + & - & - \\
\hline \multirow{2}{*}{ 笛色色 } & $50 "$ & - & - & - & - & - \\
\hline & $60 "$ & - & - & - & - & - \\
\hline \multirow{2}{*}{$\begin{array}{l}\text { 乳酸菌 } \\
\text { 椾桿菌 }\end{array}$} & $50 "$ & $H$ & $H$ & $H$ & $H$ & + \\
\hline & $60 "$ & + & + & + & - & - \\
\hline \multirow{2}{*}{ 大腸菌 } & $50 " 1$ & H & H & $H$ & + &. \\
\hline & $60 "$ & - & - & - & - & - \\
\hline
\end{tabular}




\begin{tabular}{|c|c|c|c|c|c|c|}
\hline 菌種 & 作用洔间 & $5^{\prime}$ & $10^{\prime}$ & $15^{\prime}$ & $30^{\prime}$ & $60^{\prime}$ \\
\hline \multirow{2}{*}{ 綠 膿 菌 } & $50^{\circ} \mathrm{C}$ & $H$ & H & $H$ & + & - \\
\hline & $60 \prime$ & - & - & - & - & - \\
\hline \multirow{2}{*}{ 糋 變 形 菌 } & 601 & H & + & + & - & - \\
\hline & 7011 & . + & - & - & - & - \\
\hline \multirow{2}{*}{ 悲跉暮菌 } & $90 \quad 1$ & $H$ & + & + & + & + \\
\hline & 100 & + & + & + & - & - \\
\hline \multirow{2}{*}{ 枯草菌 } & $90 \prime \prime$ & H & + & + & + & + \\
\hline & 100011 &.$^{-}$ & - & - & - & - \\
\hline \multirow{2}{*}{ 根 狀 菌 } & $90 "$ & + & + & + & + & - \\
\hline & $100 \quad 1 /$ & - & - & - & - & - \\
\hline
\end{tabular}

即于分離諸菌ノ內球菌八熟二對スル抵抗一般二强カラズ, 橙色㡀葫狀球菌及

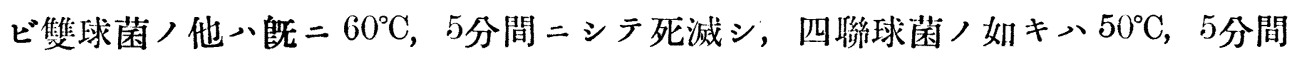
ニシテ死滅シタリ，之二反シ桿菌中芽胞ヨ有スル婜鈴著菌, 枮草菌, 根狀菌、 $90^{\circ} \mathrm{C}, 15$ 分間二シテ克ク生存シ, 特二前者 $100^{\circ} \mathrm{C}, 30$ 分問二シテ漱名死減入.

\section{第 4 節 分離諸菌ノ酸及ビあるかりニ}

\section{對スル態度二就テ}

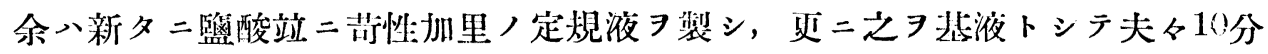
1，20分 $1 ， 50$ 分 1 ，及ビ100分 1 定規液 7 製出 シ，是等定規液1.0c中中二分離諸菌 ノ寒天科面 24 時間培養ヨリ科量セル $1.0 \mathrm{mg}$ 菌量ヅッヨ浮游セシメ, 5分, 10分 15 分, 30 分, 1 時間 ト夫々時間 7 割シテ 1 日金耳量ヅッ釣收シ，寒天科面二移 植培養シ, 集落發生ノ有無二依リテ叙上諸菌ノ酸及ビあるかり二對スル態度 檢査制定七リ，其ノ成績第 10 表乃至第 11 表ノ如シ. 
伊落雄迅

第 10 表 各種定規監酸液 $コ$ 以テセル試驗

\begin{tabular}{|c|c|c|c|c|c|c|c|c|c|c|c|c|c|}
\hline 菌種 & $\begin{array}{c}\text { 作用 } \\
\text { 時間 } \\
\text { 漕度 }\end{array}$ & $5^{\prime}$ & $10^{\prime}$ & $15^{\prime}$ & $30^{\prime}$ & $60^{\prime}$ & 菌種 & $\begin{array}{c}\text { 作用 } \\
\text { 時間 } \\
\text { 濃度 }\end{array}$ & $5^{\prime}$ & $10^{\prime}$ & $15^{\prime}$ & $30^{\prime}$ & $6 \mathrm{~J}^{\prime}$ \\
\hline \multirow{5}{*}{ 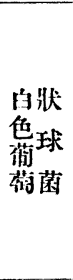 } & $\mathrm{n} / 1$ & - & - & - & - & - & \multirow{5}{*}{$\begin{array}{l}\text { 大 } \\
\text { 踼 } \\
\text { 菌 }\end{array}$} & $\mathbf{n} / 1$ & - & - & - & - & - \\
\hline & $\mathbf{n} / 10$ & - & - & - & - & - & & $\mathbf{n} / 10$ & - & - & - & - & - \\
\hline & $\mathbf{n} / 20$ & - & - & - & - & - & & $\mathbf{n} / 20$ & + & - & - & - & - \\
\hline & $\mathbf{n} / \tilde{0} 0$ & - & - & - & - & - & & $\mathrm{n} / 50$ & + & + & - & - & - \\
\hline & $\mathbf{n} / 100$ & H & + & - & - & - & & $\mathbf{n} / 100$ & $H$ & + & + & + & - \\
\hline \multirow{5}{*}{$\begin{array}{l}\text { 橙壯 } \\
\text { 色球 } \\
\text { 蓝得 }\end{array}$} & $\mathrm{n} / 1$ & - & - & - & - & - & \multirow{5}{*}{$\begin{array}{l}\text { 綠 } \\
\text { 膿 } \\
\text { 菌 }\end{array}$} & $\mathrm{n} / 1$ & - & - & - & - & - \\
\hline & $\mathrm{n} / 10$ & - & - & - & - & - & & $\mathbf{n} / 10$ & - & - & - & - & - \\
\hline & $\mathbf{n} / 20$ & - & - & - & - & - & & $\mathbf{n} / 20$ & - & - & - & - & - \\
\hline & $\mathbf{n} / 50$ & - & - & - & - & - & & $\mathrm{n} / 50$ & + & + & - & - & - \\
\hline & $\mathrm{n} / 100$ & + & + & + & - & - & & $\mathbf{n} / 100$ & H & + & + & - & - \\
\hline \multirow{5}{*}{ 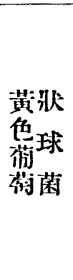 } & $\mathrm{n} / 1$ & - & - & - & - & - & \multirow{5}{*}{$\begin{array}{l}\text { 普變 } \\
\text { 形 } \\
\text { 通菌 }\end{array}$} & $\mathbf{n} / 1$ & - & - & - & - & - \\
\hline & $\mathrm{n} / 10$ & - & - & - & - & - & & $\mathbf{n} / 10$ & + & + & - & - & - \\
\hline & $\mathrm{n} / 20$ & - & - & - & - & - & & $\mathrm{n} / 20$ & H & $H$ & $H$ & + & - \\
\hline & $\mathrm{n} / 50$ & - & - & - & - & - & & $\mathrm{n} / 50$ & $H$ & H & H & HI & $\mathrm{H}$ \\
\hline & $\mathrm{n} / 1.00$ & - & - & - & - & - & & $\mathrm{n} / 100$ & $H$ & H & $H$ & Ht & $H$ \\
\hline \multirow{5}{*}{$\begin{array}{l}\text { 灰状 } \\
\text { 白球 } \\
\text { 色菌 }\end{array}$} & $\mathrm{n} / 1$ & - & - & - & - & - & \multirow{5}{*}{$\begin{array}{l}\text { 哭 } \\
\text { 鈴 } \\
\text { 䍘 }\end{array}$} & $\mathbf{n} / 1$ & $H$ & + & + & + & + \\
\hline & $\mathrm{n} / 10$ & - & - & - & - & - & & $\mathrm{n} / 10$ & H & H & $H$ & + & + \\
\hline & $\mathrm{n} / 20$ & + & - & - & - & - & & $\mathrm{n} / 20$ & H & H & $H$ & $H$ & $H$ \\
\hline & $\mathrm{n} / 50$ & + & + & + & + & - & & $\mathbf{n} / 50$ & $H$ & $H$ & $H$ & $H$ & H \\
\hline & $\mathbf{n} / 100$ & + & + & + & + & - & & $\mathbf{n} / 100$ & $H$ & H & $H$ & $H$ & H \\
\hline \multirow{5}{*}{$\begin{array}{l}\text { 黄偝 } \\
\text { 聯 } \\
\text { 救 } \\
\text { 色 }\end{array}$} & $\mathrm{n} / 1$ & - & - & - & - & - & \multirow{5}{*}{$\begin{array}{l}\text { 枮 } \\
\text { 草 } \\
\text { 菌 }\end{array}$} & $\mathrm{n} / 1$ & + & + & + & - & - \\
\hline & $\mathrm{n} / 10$ & - & - & - & - & - & & $\mathrm{n} / 10$ & H & + & + & + & + \\
\hline & $\mathrm{n} / 20$ & - & - & - & - & - & & $\mathrm{n} / 20$ & $H$ & $H$ & $H$ & $H$ & + \\
\hline & $\mathrm{n} / 50$ & + & + & + & - & - & & $\mathrm{n} / 59$ & H & H & H & $H$ & $H$ \\
\hline & $\mathrm{n} / 100$ & + & + & + & + & + & & $\mathbf{n} / 100$ & $H$ & H & H & $H$ & $H$ \\
\hline \multirow{5}{*}{ 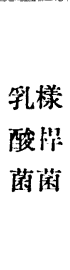 } & $\mathbf{n} / 1$ & - & - & - & - & - & \multirow{5}{*}{$\begin{array}{l}\text { 根 } \\
\text { 狀 } \\
\text { 菌 }\end{array}$} & $\mathrm{n} / 1$ & - & - & - & - & - \\
\hline & $\mathbf{n} / 10$ & - & - & - & - & - & & $\mathbf{n} / 10$ & + & + & + & + & + \\
\hline & $\mathrm{n} / 20$ & - & - & - & - & - & & $\mathbf{n} / 20$ & H & $H$ & $H$ & $H$ & $H$ \\
\hline & $\mathrm{n} / 50$ & - & - & - & - & - & & $\mathrm{n} / 50$ & H & H & H & $H$ & $H$ \\
\hline & $\mathbf{n} / 100$ & - & - & - & - & - & & $\mathbf{n} / 100$ & H & $H$ & $H$ & $H$ & $H$ \\
\hline
\end{tabular}


第 11 表 各種定規苗性加里液 $习$ 以テセル試驗

\begin{tabular}{|c|c|c|c|c|c|c|c|c|c|c|c|c|c|}
\hline 菌種 & 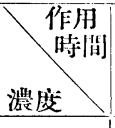 & $5^{\prime}$ & $10^{\prime}$ & $15^{\prime}$ & $30^{\prime}$ & $60^{\prime}$ & 菌種 & 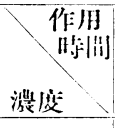 & $5^{\prime}$ & $10^{\prime}$ & $15^{\prime}$ & $30^{\prime}$ & $63^{\prime}$ \\
\hline \multirow{5}{*}{ 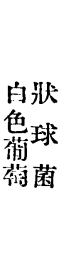 } & $\mathbf{n} / 1$ & - & - & - & - & - & \multirow{5}{*}{$\begin{array}{l}\text { 大 } \\
\text { 腸 } \\
\text { 蒋 }\end{array}$} & $\mathbf{n} / 1$ & - & - & - & - & - \\
\hline & $\mathbf{n} / 10$ & - & - & - & - & - & & $\mathrm{n} / 10$ & - & - & - & - & - \\
\hline & $\mathrm{n} / 20$ & $H$ & + & - & - & - & & $\mathrm{n} / 20$ & - & - & - & - & - \\
\hline & $\mathrm{n} / 50$ & H & \# & HH & H & H & & $\mathrm{n} / 50$ & Ht & H & $H$ & H & $H$ \\
\hline & $\mathbf{n} / 100$ & Ht & H & $H$ & H & HI & & $\mathbf{n} / 100$ & H & H & H & Ht & $H H$ \\
\hline \multirow{5}{*}{$\begin{array}{l}\text { 橙状 } \\
\text { 蔽球 } \\
\text { 葡菌 }\end{array}$} & $\mathrm{n} / 1$ & - & - & - & - & - & \multirow{5}{*}{$\begin{array}{l}\text { 綠 } \\
\text { 膿 } \\
\text { 蒌 }\end{array}$} & $\mathbf{n} / 1$ & - & - & - & - & - \\
\hline & $\mathrm{n} / 10$ & - & - & - & - & - & & $\mathrm{n} / 10$ & - & - & - & - & - \\
\hline & $\mathrm{n} / 20$ & + & - & - & - & - & & $\mathbf{n} / 20$ & - & - & - & - & - \\
\hline & $\mathrm{n} / 50$ & $H$ & $H$ & + & - & - & & $\mathbf{n} / 50$ & + & + & - & - & - \\
\hline & $\mathrm{n} / 10 \mathrm{~J}$ & H & H & $H$ & $H$ & + & & $\mathbf{n} / 100$ & $H$ & + & + & - & - \\
\hline \multirow{5}{*}{$\begin{array}{l}\text { 黄师 } \\
\text { 色球 } \\
\text { 菊菌 }\end{array}$} & $\mathbf{n} / 1$ & - & - & - & - & - & \multirow{5}{*}{$\begin{array}{r}\text { 晋變 } \\
\text { 形 } \\
\text { 通菌 }\end{array}$} & $\mathrm{n} / 1$ & - & - & - & - & - \\
\hline & $\mathrm{n} / 10$ & $H$ & + & + & + & + & & $\mathrm{n} / 10$ & - & - & - & - & - \\
\hline & $\mathbf{n} / 20$ & $H$ & $H$ & $H$ & + & + & & $\mathrm{n} / 20$ & + & + & - & - & - \\
\hline & $\mathrm{n} / 50$ & HH & $H$ & HI & $H$ & $H$ & & $\mathrm{n} / 50$ & $H$ & $H$ & + & + & + \\
\hline & $\mathbf{n} / 100$ & H & H & W & H & $H$ & & $\mathbf{n} / 100$ & $H$ & H & $H$ & $H$ & + \\
\hline \multirow{5}{*}{$\begin{array}{l}\text { 灰状 } \\
\text { 白球 } \\
\text { 色菌 }\end{array}$} & $\mathrm{n} / 1$ & + & - & - & - & - & \multirow{5}{*}{ 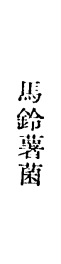 } & $\mathrm{n} / 1$ & $H$ & $H$ & + & + & + \\
\hline & $\mathbf{n} / 10$ & H & H & $H$ & + & + & & $\mathrm{n} / 10$ & $H$ & $H$ & $H$ & + & + \\
\hline & $\mathbf{n} / 20$ & H & $H$ & \# & $H$ & $H$ & & $\mathrm{n} / 20$ & $H$ & $H$ & $H$ & + & + \\
\hline & $\mathbf{n} / 50$ & $H$ & \# & H & H & W & & $\mathrm{n} / 5 \mathrm{~J}$ & $H$ & H & $H$ & $H$ & H \\
\hline & $\mathrm{n} / 103$ & HH & H & H & H & H & & $\mathbf{n} / 1 \mathrm{CO}$ & H & HH & H & $H$ & H \\
\hline \multirow{5}{*}{$\begin{array}{l}\text { 黄四 } \\
\text { 聯 } \\
\text { 色竹 }\end{array}$} & $\mathrm{n} / 1$ & - & - & - & - & - & \multirow{5}{*}{$\begin{array}{l}\text { 枮 } \\
\text { 茫 } \\
\text { 莉 }\end{array}$} & $\mathrm{n} / 1$ & + & + & + & - & - \\
\hline & $\mathbf{n} / 10$ & $H$ & + & + & + & + & & $\mathrm{n} / 10$ & $H$ & $H$ & + & + & + \\
\hline & n/20 & H & HI & H & $H$ & + & & $\mathrm{n} / 20$ & $H$ & H & $H$ & $H$ & $H$ \\
\hline & $\mathrm{n} / 50$ & $\mathrm{HH}$ & $H$ & $\mathrm{Ht}$ & $\mathrm{HH}$ & $H$ & & $\mathrm{n} / 50$ & $H$ & $H H$ & $\mathrm{Ht}$ & $H$ & $H$ \\
\hline & $\mathbf{n} / 100$ & HI & H & H & HH & H & & $\mathbf{n} / 100$ & H & Ht & H & $H$ & $H$ \\
\hline \multirow{5}{*}{$\begin{array}{l}\text { 乳樣 } \\
\text { 酸桿 } \\
\text { 菌菌 }\end{array}$} & $\mathrm{n} / 1$ & - & - & - & - & - & \multirow{5}{*}{$\begin{array}{l}\text { 根 } \\
\text { 状 } \\
\text { 菌 }\end{array}$} & $\mathrm{n} / \mathrm{l}$ & + & + & + & + & + \\
\hline & $\mathrm{n} / 10$ & - & - & - & - & - & & $\mathrm{n} / 10$ & H & $H$ & $H$ & $H$ & + \\
\hline & $\mathbf{n} / 20$ & - & - & - & - & - & & $\mathbf{n} / \mathbf{2 0}$ & H & H & H & $H$ & $H$ \\
\hline & $\mathrm{n} / 50$ & - & - & - & - & - & & $\mathbf{n} / 50$ & W & H & H & H & HH \\
\hline & $\mathbf{n} / 100$ & + & + & + & + & + & & $\mathbf{n} / 100$ & $\mathrm{Ht}$ & HI & H & H & HH \\
\hline
\end{tabular}




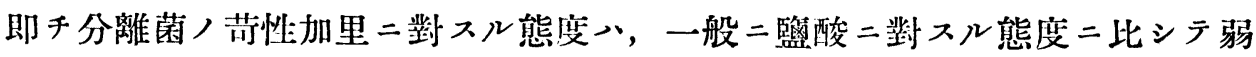
キヨ認ム。但シ莎性加里二對シテ抵抗强大ナル菌株ハ, 監酸二對シテモ亦一定 ノ抵抗ヨ示セリ，而シテ嚚鈴薯菌ハ之ヨ定規監酸中二 1 時間二亘りテ放置スル モ仯ホ且ッ生存セリ。一方供試糠味㴰ノ總酸度ガ特二熟成期二於テ甚ダ高キモ ノアルニ拘ラズ，前記監酸二對シテ抵抗弱キ菌株ヨ證明シ得タルハ，是等菌株 ガ糠味骝固有ノ細莳ニアラズシテ, 偶々一時的二外界ョリ侵入セシモノニアラ ザルナキャア恐ハシモルモ, 而モ亦熟成ト基二各種糠味骝习通ジテ多數二生存 シ, 或ル種ノ糠味㫮中二八殆ド純粹培篒ノ狀 $コ$ 呈シテ發育スル乳酸桿菌ノ如キ

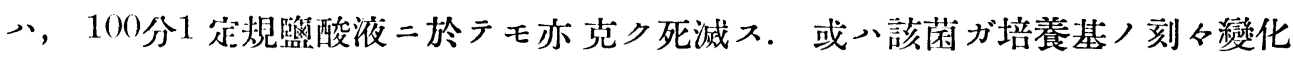
スル水素いお九䟴度二對シ順應シ, 慣性ヨ得タルモノトモ思惟セラルルョ以テ

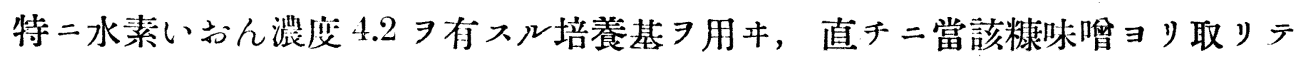

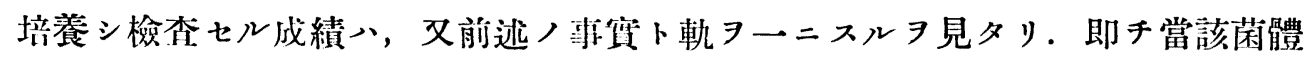
八䜿酸酸性二對シ特二抵抗弱キモノトシテ忍惟スルノ他ナキモノトス。

\section{第 5 篩 分離諸菌ノ動物二對スル毒性}

\section{二就テ}

分離諸莉ノ內球菌二就テハ, 夫々寒天斜面 24 時間培養 $コ$ 取リ，菌量 $1.0 \mathrm{mg}$ 對 生理的食監水 $10.0 \mathrm{cc}$ ノ比 成熟健赏もるもっとノ拔毛侧腹部皮内二注射シ，直徑約 $1.0 \mathrm{~cm}$ ノ浸潤部 七シメ, 爾後5 日間二亘リテ局所反應 ヨ檢セル二橙色葡萄狀球菌ノ 1 株ノミ 接種第 2 日二於テ極メテ小サキ痕跡狀膿泡 八全然何等ノ反應 $コ$ 呈シ來ラズ. 次二分離桿菌ノ毒力檢査ニハ專ラまうすョ使 用シタリ。即チ各種寒天斜面 24 㭙間培養 7 取リ, 包含菌量 7 區別シテ各種菌浮 游液 $ᄏ$ 作リ, 體重 $10.0 \mathrm{~g}$ 內外健常まうす,腹腔內二注射シ, 爾後5 日間二亘リテ 生死 $\ni$ 觀祭セり。其ノ成績、第 12 表ノ如ク, 大腸菌ノミ體重 $10.0 \mathrm{~g}=$ 對シ, 0.05 $\mathrm{mg}$ 菌量ヨ以テシテ整死セシメタjニ拘ラズ, 爾餘各菌種・大量ヨ注射シテ動 物ハ元科旺盛二止マレルヨ見タリ.

第 12 表 


\begin{tabular}{|c|c|c|c|c|c|c|c|}
\hline 菌 & $\begin{array}{c}\text { まうす } \\
\text { 番 號 }\end{array}$ & 體 $(\mathrm{g})$ 重 & $\begin{array}{l}\text { 注射菌液 } \\
\text { 量 (cc) }\end{array}$ & $\begin{array}{c}\text { 注射菌量 } \\
(\mathrm{mg})\end{array}$ & $\begin{array}{c}\text { 能重 } 10.0 \mathrm{~g} \\
\text { 数注射药量 } \\
(\mathrm{mg})\end{array}$ & $\begin{array}{l}24 \text { 時 } \\
\text { 間後 }\end{array}$ & $\begin{array}{l}\text { 48時 } \\
\text { 閌後 }\end{array}$ \\
\hline \multirow{5}{*}{$\begin{array}{l}\text { 孚嘲 } \\
\text { 酸 } \\
\text { 蓧 } \\
\text { 樣菌 }\end{array}$} & 1 & 10.0 & 0.2 & 0.2 & 0.2 & 生 & 生 \\
\hline & 2 & 8.7 & $0: 2$ & 0.5 & 0.6 & 生 & 生 \\
\hline & 3 & 11.2 & 0.2 & 1.0 & 0.9 & 生 & 坐: \\
\hline & 4 & 9.2 & 0.2 & 2.0 & 2.2 & 死 & \\
\hline & 5 & 9.8 & 0.2 & 5.0 & 5.1 & 㸺 & 生 \\
\hline \multirow{5}{*}{$\begin{array}{l}\text { 大 } \\
\text { 腸 } \\
\text { 荫 }\end{array}$} & 6 & 8.9 & 0.2 & 0.02 & 0.02 & 生 & 生 \\
\hline & 7 & 10.2 & 0.2 & 0.05 & 0.05 & 死 & \\
\hline & 8 & 10.0 & 0.2 & 0.1 & 0.1 & 死 & \\
\hline & 9 & 9.3 & 0.2 & 0.5 & 0.5 & 死 & \\
\hline & 10 & 9.9 & 0.2 & 1.0 & 1.1 & 死 & \\
\hline \multirow{5}{*}{$\begin{array}{l}\text { 綠 } \\
\text { 膿 } \\
\text { 䕡 }\end{array}$} & 11 & 8.2 & 0.2 & 0.2 & 0.2 & 生: & 生 \\
\hline & 12 & 10.0 & 0.2 & 0.5 & 0.5 & 本 & 生 \\
\hline & 13 & 10.8 & 0.2 & 1.0 & 0.9 & 牛: & 生: \\
\hline & 14 & 9.2 & 0.2 & 2.0 & 2.2 & 生 & 生 \\
\hline & 15 & 9.8 & 0.2 & 5.0 & 5.0 & 尘 & 生 \\
\hline \multirow{5}{*}{$\begin{array}{l}\text { 蓝 } \\
\text { 通 } \\
\text { 戀 } \\
\text { 莉 }\end{array}$} & 16 & 8.9 & 0.2 & 0.2 & 0.2 & 生 & 尘 \\
\hline & 17 & 10.2 & 0.2 & 0.5 & 0.5 & 生: & 生 \\
\hline & 18 & 9.4 & 0.2 & 2.0 & 2.4 & 生: & 生 \\
\hline & 19 & 9.0 & 0.4 & 5.0 & 5.6 & 生 & 生 \\
\hline & 20 & 11.2 & 0.2 & 10.0 & 9.0 & 生: & 生 \\
\hline \multirow{5}{*}{$\begin{array}{l}\text { 婜 } \\
\text { 鈴 } \\
\text { 罯 }\end{array}$} & 21 & 8.7 & 0.2 & 0.2 & 0.23 & 生: & 生 \\
\hline & 22 & 10.0 & 0.2 & 0.5 & 0.5 & 生 & 生 \\
\hline & 23 & 10.2 & 0.2 & 1.0 & 0.98 & 生 & 生 \\
\hline & 24 & 10.2 & $0.2^{\bullet}$ & 2.0 & 1.96 & 生 & 生 \\
\hline & 25 & 10.7 & 0.4 & 5.0 & 4.7 & 死 & \\
\hline \multirow{5}{*}{$\begin{array}{l}\text { 枯 } \\
\text { 草 } \\
\text { 菌 }\end{array}$} & 26 & 9.5 & 0.2 & 0.5 & 0.5 & 生 & 生 \\
\hline & 27 & 9.0 & 0.2 & 1.0 & 1.1 & 生 & 生 \\
\hline & 23 & 10.2 & 0.2 & 2.0 & 2.0 & 生 & 生 \\
\hline & 29 & 8.7 & 0.2 & 5.0 & 5.7 & 生 & 生 \\
\hline & 30 & 9.7 & 0.4 & 10.0 & 10.3 & 死 & \\
\hline
\end{tabular}




\begin{tabular}{|c|c|c|c|c|c|c|c|}
\hline & & & 苦 & & \multicolumn{2}{|c|}{ (1487) } \\
\hline & 31 & 10.2 & 0.2 & 0.2 & 0.2 & 生 & 生 \\
\hline 根 & 32 & 10.0 & 0.2 & 0.5 & 0.5 & 生 & 生 \\
\hline 状 & 33 & 12.0 & 0.2 & 1.0 & 0.83 & 生 & 生 \\
\hline 附 & 34 & 9.5 & 0.4 & 2.0 & 2.1 & 死 & \\
\hline & 35 & 11.0 & 0.4 & 5.9 & 4.5 & 死 & \\
\hline
\end{tabular}

\section{總括}

余八邦人家庭二於ラ日常使用セラレアル成熟粶味㗍 5 種, 站二余ガ新タ二調

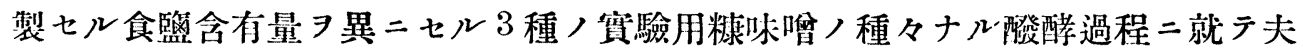
々包含細菌 ヨ分離シ，〈゙らむ陽性ノ球菌7株，〈゙らむ陽性ノ隻球菌及ビ四聯球菌 各 1 株, 〈゙らむ陰性桿菌 6 株, 〈゙らむ陽性桿菌 7 株, 合計 22 株 $习$ 手二シ, 夫々 ニッキ各種性狀ヨ檢査シタルニ, 球菌ハ白色, 橙色, 黄色茂萄狀球菌及ビ戻白 色隻球莉站二黄色四聯球菌ニシテ，ぐらむ陽性桿菌八馬鈴薯菌，枯草菌，根狀

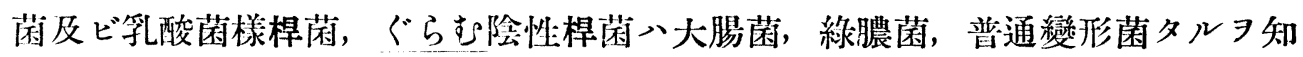
リ得タリ。而シテ被檢各種粶味骝及ビ其ノ包含諸菌ノ性狀乃至關係二就テ知》 得タル耕窑习總括スレバ下ノ如シ。

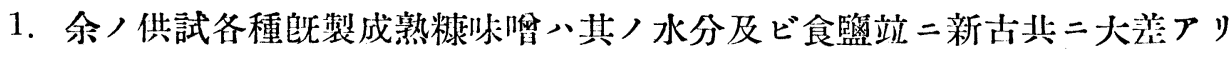

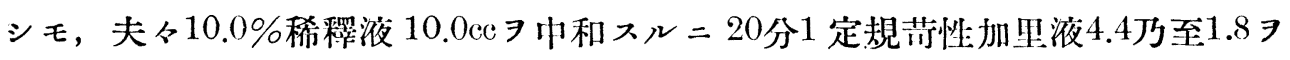
要シ, 水素い战久濃度、4.4万至4.0ナリ。

2. 食監含有量 $夫$ 夫 $10.0 \% ， 30.0 \% ， 60.0 \%$ トシ, 米棣二對シ倍量ノ水道水

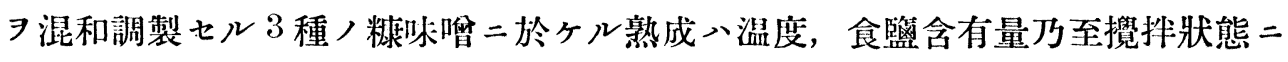
ヨリテ異ルモ，攝氏 $5^{\circ} \mathrm{C}$ 万至 $14^{\circ} \mathrm{C}=$ 於テ，1日1回ノ擤汼ニョリ十數日ニシテ熟 成ス. 而シテ調彆第 23 日迄二於ヶル $10.0 \%$ 稀釋液 $10.0 \mathrm{cc}$ / 最高總酸度ハ, 10 分 1 定規監酸液 2.82 乃至 0.81 二相當シ，水素いおん濃度、 4.2 乃至 4.6 二達入，是等總

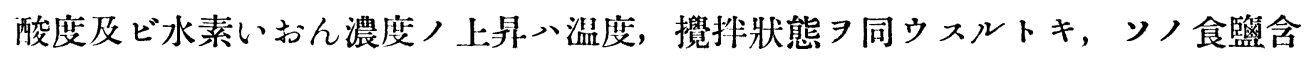
有量二逆比例 .

3. 既製成熟糠味唓中二於ヶル包含細菌 $ル ル 2$ 、 1 種特殊ノ乳酸菌樣桿菌ニシテ, 他ノ諸菌、每常證明シ得ズ.

4. 余八調製セル筫驗用糠味骝ニアリテハ, 調製第3日乃至第5日ニシテ乳酸 
菌樣桿菌現レ, 總酸度, 上年卜共二增加シ, 熟成期二至りテ多數又、無數二出 現ス. 之二反シ他八諸菌ハ何レモ每常定在シテ證明セラレズ, 且調製後總酸度 仯办低キ時期二於テ多數之ガ存在习證スルニ拘ラズ, 熟成スルニ及ンデ漸次减 少ノ傾向习示セリ.

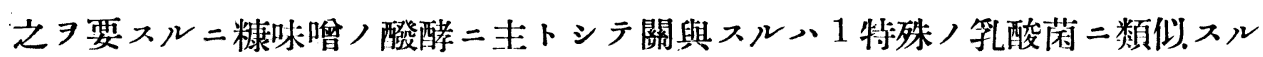
桿菌ナリ, 本菌ハぐらむ陽性ニシテ, 芽胞, 鞭毛习缺キ,ぶいよん, ぺぷさん 水二發育セズ, 普通寒天特二蔽菊糖加寒天二良ク發育シ, 透明水滴狀微細菲薄

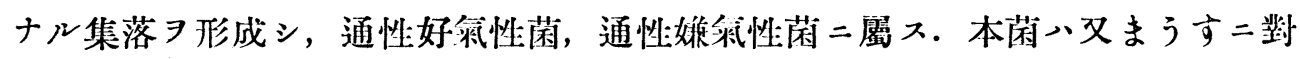

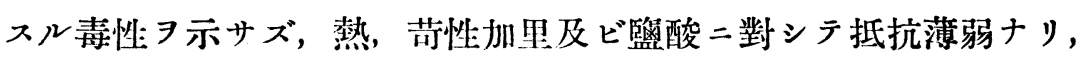

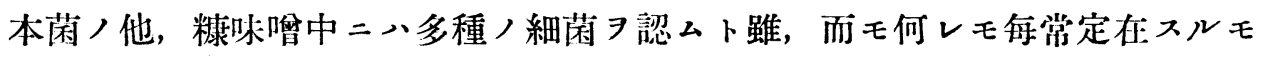

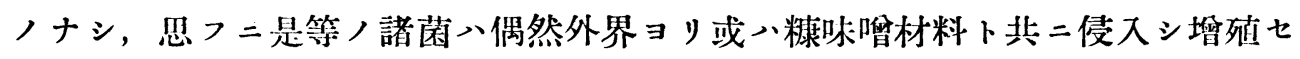
ルモノ二他ナラズ. 而シテ是等雜菌中, 橙色葡荇狀球菌及ビ大腸菌ハ夫々もる もっこ及ビまうす二對シテ稍々毒性ヨ發揮セリト雖, 而モ足等ノ各菌入何レモ 諸種要約二對スル抵抗微弱ニシテ, 糠味嗊中二於テハ, 單二一時的生存 $习$ 持䋶 シ得ルニ過ギズ。

(文 献 後 出) 


\section{糠味噌, 細菌學的研究 \\ 第 2 編 糠味噌二混和七ル消化器傳染病） \\ 病原菌ノ運命二關スル㸴究}

笠原小兒保健研究所

伊庭吉 雄

\section{【内容 抄 錄】}

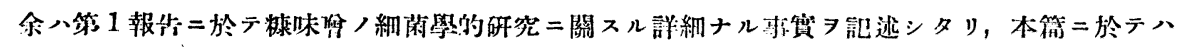

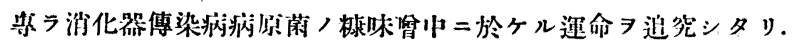

\section{目次}

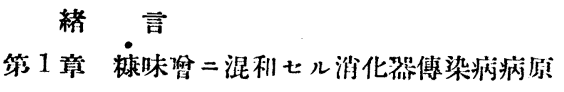
菌ノ運命二就 $\div$

第 1 饰 偕試材料站 $=$ 检查方法

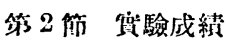

第3 節 小 括

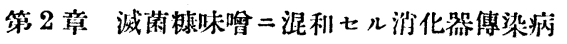
为污原萑

第 1 管 供萢材料站二检查方法

第 2 管 贯驗成綪

第3筑 小 括

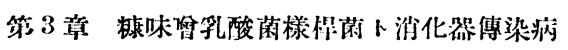
病原菌卜人拈抗作用 =就示
}

第 1 筫 試驗方法

\section{第 2 䈱 定驗成綪 \\ 第 3 管 小 括}

第 4 章 各種濃度/乳酸溶液中二於ヶル消化 器傅染病病原菌, 運命二就テ

第 1 節 試驗方法

第 2 管 霓驗成績

第3 節 小 括

第 5 章 各種湄度, 食臨溶液中二於ヶル消化 器傳染病病原菌/连命二就テ

第 1 節 試驗方法

第 2 節 䗆驗成縝

第3 筑 小 括

總 括

\section{粕言}

暴二余入自家製諸種栤咏骝二就テ其ノ包含細菌 7 分離シ, 孚酸菌樣 1 桿菌ガ 調製後數日ノ棣味稩中二出現シ，成熟卜共二增殖シ，成熟完成期二至り恰モ純 粹培養二於ヶルガ如ク無數二出現スルコトヨ認メ恐ラクハ本菌ガ糠味嘴/乳酸 酸酵二猋與スル主體菌ナルコトニ言及セリ。而シテ余入進ンデ粶味骝二消化器 系統ヨ侵䛨スル諸種病原菌ヨ混入シテ是等各種, 運命ヨ知ラントシ, 新タ二本 研究二着手シタリ。

糠味㗱ニ於ヶル消化器傳染病病原菌ノ運命二就テハ暴二依田ガぱらちふす菌 
二就テ實驗セルニ次デ，渡邊、ちふす菌二就テ貨驗シ，糠味筥ノ殺菌力八酸 度, 温度, 食監含有量二關係シ, 更二當該糠味骝, 仗用程度二因リテ一定七ズ

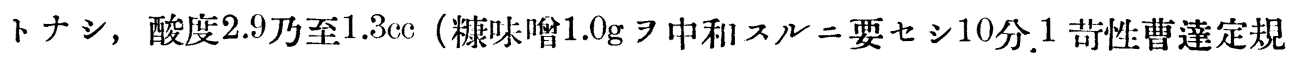

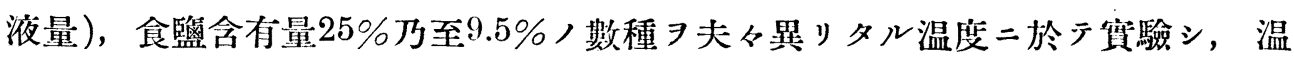
度高ク酸度高キ㭙ハ混和セルちふす菌、即二數忮閏ニシテ死隇シ，秋冬期ノ温

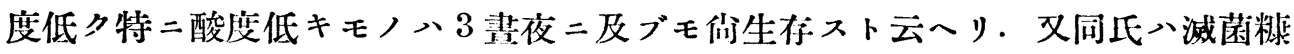

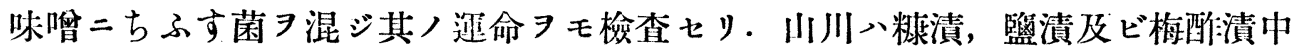

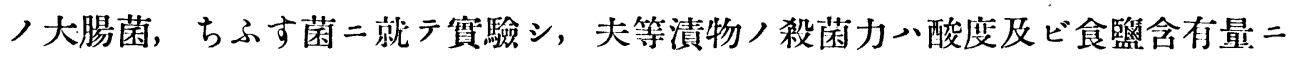

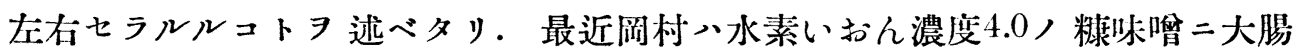
菌站二葡萄狀球菌 7 混ジ，大腸菌ハ 9 乃至 12 時間後二於テハ殆ド死減シ，更二 24 時間後二八全ク死隇スル二對シ，蒱萄狀球藏入耐酸性遥カ二弱ク 9 乃至 12 時 間後二ハ全ク死隇スト七リ。

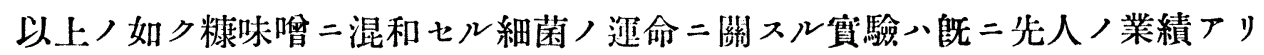
卜雖, 而も供試細菌、大腸菌，ちふす菌，ばらちふす菌等二限ラレ未ダ消化器

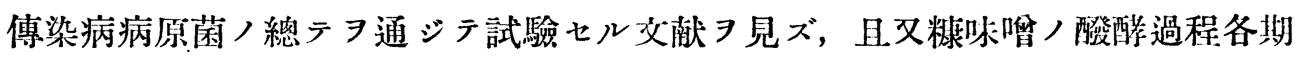
二就テ之ヨ試ミタル業績二接セズ, 是二於テ余》倛驗用トシテ新タ二調製セル 糠味唄ノ成熟過程 7 追究シ，其ノ第 3 日，第 7 日，第 14 日及ビ第 21 日ノ各時期 ヨ劃シテ消化器傳染病病原菌タルちふす菌, ぱらちふす $\mathrm{A}$ 菌, ぱらちふす $\mathrm{B}$ 菌, 赤痢 (志賀型) 菌, これら菌站二普通大腸菌, 6 株 $夫$ 夫混和シ, 足等諸菌, 運命二就テ檢討シ, 續テ三三ノ研究 $コ$ 行ヒ, 一定ノ成績 $コ$ 得タル 以 以茲二報 告セントス.

\section{第 1 章 糠味糠二混和セ儿消化器傅染}

\section{病病原菌ノ運命二就テ}

\section{第 1 節 供試材料站二檢査方法}

既二前編二於テ述ベタル如ク糠味噃ノ總酸度未ダ上鸟セザル時期ニアリテメ 混入雜菌多數ナルガ篇, 新タ二混和セル病原菌ヨ檢索スルニ當リ, タトヒ夫々 適當ナル特選培琹基 トス，而シテ糠味噌成熟シ，外界侵入雜菌、概ネ死減シ，獨り粶味骝乳酸菌樣 
桿菌ノミ繁殖スル時期卜踓, 容量大ナル糠味嚊中二微量ノ病原菌习加へテ之ガ 生死 追究スルハ留際的手技二於テ頗ル困難ナリ。 之二對シ先人ノ苫心大ナル モノアリ，各自冬種ノ方法ヨ案出，實驗二從ヒ居レリ。即于依田、供試菌ヨ材 料二混ジ時間的二糠味骝ノ一小部分ヨ探取シ直接ごるがるすきー・こんらーぢ 培養其上二塗布セリ。渡邊モ最初糠味噌 $30.0 \mathrm{~g}$ 二種々ノ菌量 $ᄏ$ 混和シ。其ノ數 白金耳

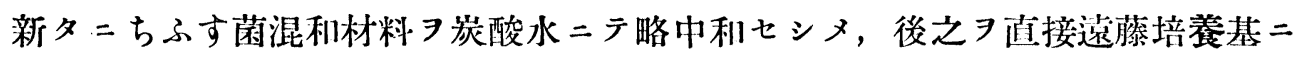
移植シ，或ハ間接二膽汁培養基，ぺ゚こん水又心一度膽汁二移シ，再ビぺぷこ ん水二移植シテ䝬菌 ニ依リテ初メテ稍々正確ナル成績ヨ得タリト述ベタリ。川川ハ糠味䁚中二菌液 ヨ浸シタル小がーぜヨ抑入シ置キ, 其ノがーぜヨリ特選培養基 ヨ用中テ增菌セ シメ，後遠藤培養基上二塗布シタルニ甚ダ正確ナル結果ヨ擧ゲ得タリト云フ。

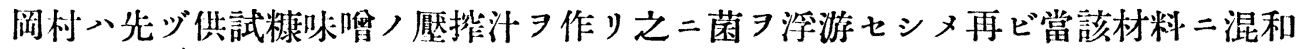

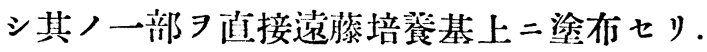

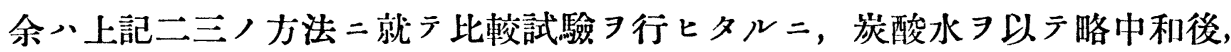

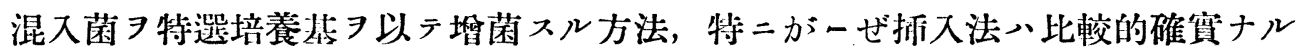
成綪ヨ擧ゲタリト雖, 而モ前者、後者二比シテ稍々速二死隇スルア見タリ。依 テ余ハ正確度及ビ貝際上ヨ考虑シ專ラがーぜ拆入法二依ルコトトセり。即チ

(A) 米糠 $100.0 \mathrm{~g} ，$ 監 $10.0 \mathrm{~g}$ ，水 $200.0 \mathrm{cc}$.

(B) 米糠 $100.0 \mathrm{~g}$ ，監 $30.0 \mathrm{~g} ，$ 水 $200.0 \mathrm{cc}$.

(C) 米䆂 $100.0 \mathrm{~g}$, 監 $60.0 \mathrm{~g}$, 水 $200.0 \mathrm{cc}$.

右ノ組成 ヨ有スル 3 種ノ粶味骝 $\ni$ 調製 シ（攝氏 $14^{\circ} \mathrm{C}$ 乃至零下 $2^{\circ} \mathrm{C}$ ノ室內二保

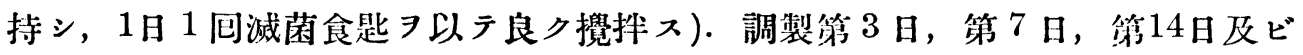
第 21 日ト日

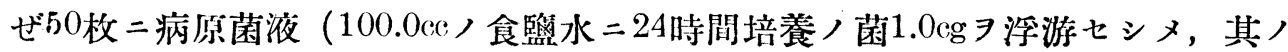
5.0ec 3100 枚ノがーぜ二浸ス）ヨ浸シタルモノヨ當該糠味嗊內各所二㨂入シ， 更二之 $\exists 37^{\circ} \mathrm{C}$ 二保ツモノ卜窂温 $\left(14^{\circ} \mathrm{C}\right.$ 乃至零下 $\left.11^{\circ} \mathrm{C}\right)$ 二保ツモノト二2分シ爾後

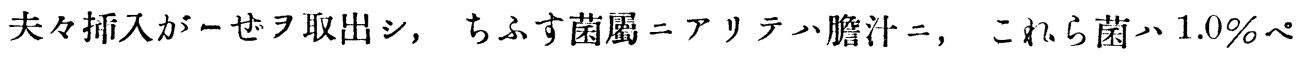

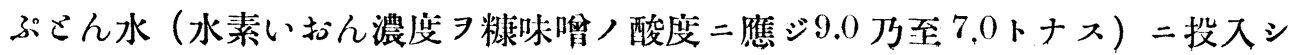


1 書夜增菌セシメ, 之ヨ更二造藤培養基二移植シタリ, 而シテ赤痢菌及ビ普通 大腸菌 $1.0 \mathrm{cc}$ 隇菌蒸熘水 $\exists$ 以テ洗滌シ, 洗滌液 $\exists$ 直接遠滕培養基二叙布 發生集落二就テ一々當該菌家兔忍没血清ニョリテ凝集試驗 二性狀 $习$ 制定セリ.

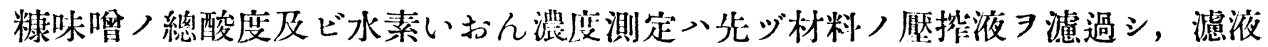
二就テ行へリ，即チ總酸度、ふえのーるふたれいんヨ標示藥トシ，滤液10.0ec ヨ中和スルニ要スル10分 1 荊性加里定規液ノ消费量 メへーりげノこんはらとーるヨ以テ测定セリ。供試䆂味骝ノ總酸度站二水素い おん濃度ヨ表示スレバ第 1 表ノ如シ.

佾供試棣味骝ノ一小部分 $\exists$ 探り $1.0 \%$ 葡萄糖寒天培養基二塗布シ 日々乳酸菌

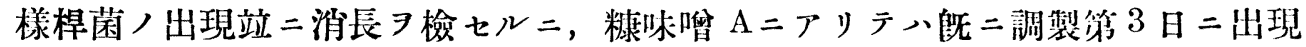

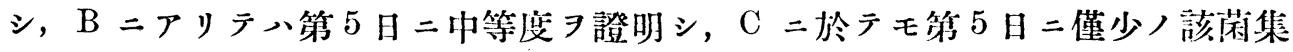
落э發生七リ。

第 1 表 糠味唄ノ總酸度・水素いおん旅度

\begin{tabular}{|c|c|c|c|c|c|c|c|}
\hline 秱 & 類 & $\begin{array}{l}\text { 檢䄳日別 } \\
\text { 總酸 } \\
\text { 度及ビ } \mathrm{P}_{\mathrm{H}}\end{array}$ & 調製妊後 & 調製第3日 & 調製第7日 & 調製第14日 & 調製第221日 \\
\hline \multirow{2}{*}{ 疗味喻 } & & 總 酸 度 & 3.9 & 9.1 & $\Sigma 6.4$ & 34.1 & 43.0 \\
\hline & & 水素いお人 & 6.0 & 5.0 & 4.6 & 4.0 & 3.8 \\
\hline \multirow{2}{*}{ "I } & \multirow{2}{*}{ B } & 總 酸 度 & 3.2 & 5.8 & 7.4 & 8.8 & 15.5 \\
\hline & & 水素いお人 & 6.0 & 5.2 & 4.8 & 4.4 & 4.2 \\
\hline \multirow{2}{*}{ "I } & & 總 酸 度 & 1.8 & 2.6 & 3.2 & 4.0 & 4.3 \\
\hline & & 水素いお人 & 6.2 & 5.4 & 5.2 & 4.8 & 4.8 \\
\hline
\end{tabular}

\section{第 2 節 富 驗成 績}

1. 普通大腸菌

調製第 3 日（總酸度，水素いおん濃度、第 1 表參照以下之二噍ズ）二普通大腸 菌 $\ni$ 混和シ, 攝氏 $14^{\circ} \mathrm{C}$ 乃至 $3^{\circ} \mathrm{C}$ 八室內二保ットキ八糠味噌 $\mathrm{A}=$ アリテハ 216 時間 $\mathrm{B}=$ アリテハ240時間， $\mathrm{C}=$ アリテハ192時間ニシテ死隇シ， $37^{\circ} \mathrm{C}$ 二保ットキハ 糠味唄 $\mathrm{A}, \mathrm{B}, \mathrm{C}$ 何レモ 144時間ニシテ混入普通大腸菌ノ死隇 $コ$ 來入。調製第 7 日二混ズレバ攝氏 $13^{\circ} \mathrm{C}$ 乃至 $1^{\circ} \mathrm{C}=$ 於テ $\mathrm{A}=$ リティ 72 時間， $\mathrm{B}=$ アリテ 96 
洔間， $\mathrm{C}=$ アリテハ 120 腙間ニシテ死減シ, $37^{\circ} \mathrm{C}=$ 於テハ $\mathrm{A} ニ ア リ テ ハ 48$ 時間 $\mathrm{B}=$ アリテハ96時間， $\mathrm{C}=$ リテハ72時間ニシテ死隇ス。調製第14日二混和セ ル成績モ略之ト同一ナリ, 即千攝氏 $14^{\circ} \mathrm{C}$ 乃至 $1^{\circ} \mathrm{C}=$ テ $\mathrm{A}=$

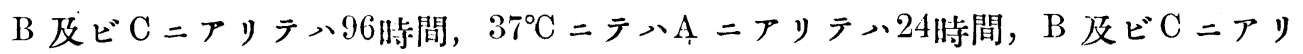
テハ72時間ニシテ菌ノ發生ヨ認メズ. 又調製第 21 日二混利スレバ室內（攝氏 14

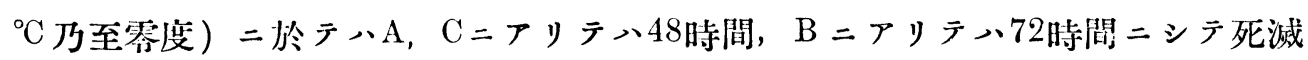
シ, $37^{\circ} \mathrm{C}=$ 於テハ $\mathrm{B}=$ アリテハ 48 時間, $\mathrm{A}$ 及ビ $\mathrm{C}=$ アテハ 24 時間ニシテ死成 スベシ，即チ是等ノ成績

第 2 㤗 調製第 3 日二混和セル普通大腸菌

\begin{tabular}{l}
\hline 種 類 \\
\hline
\end{tabular}

第 3 﨎 調製第 7 日二混和セル普通大腸菌

\begin{tabular}{|c|c|c|c|c|c|c|c|c|c|c|c|c|c|c|}
\hline 種 類 & 時废 ${ }^{\circ} \mathrm{C}$ & $\mid 3$ 洔间 & $6 "$ & $12 " \prime$ & $24 \prime \prime$ & $48 "$ & $72 \prime \prime$ & $96 "$ & $120 "$ & 144 " & $163 "$ & $192 "$ & $216 "$ & $240 \prime \prime$ \\
\hline \multirow{2}{*}{ 槺味啥 A } & $13-1$ & + & + & + & + & + & - & - & - & - & - & - & - & - \\
\hline & 37 & + & + & + & + & - & - & - & - & - & - & - & - & - \\
\hline \multirow{2}{*}{ " B } & $13-1$ & + & + & + & + & + & + & - & - & - & - & - & - & - \\
\hline & 37 & + & + & + & + & + & + & - & - & - & - & - & - & - \\
\hline \multirow{2}{*}{ " } & $13-1$ & + & + & + & + & + & + & + & - & - & - & - & - & - \\
\hline & 37 & + & + & + & + & + & - & - & - & - & - & - & - & - \\
\hline
\end{tabular}

第 4 表 調製笨 14 日二混和セル普通大晹菌 


\begin{tabular}{|c|c|c|c|c|c|c|c|c|c|c|c|c|c|c|c|}
\hline 種 & 類 & 時 间 & 3時問] & $6 " \prime$ & $12 \prime \prime$ & $24 \prime \prime$ & $4 S^{\prime \prime}$ & $72 "$ & $93 "$ & 120 " & 144 " & $168 \prime \prime$ & 192 " & $21.6 "$ & $240 "$ \\
\hline \multirow{2}{*}{\multicolumn{2}{|c|}{ 棣味啠 $\mathrm{A}$}} & $14-1$ & + & + & + & + & + & - & - & - & - & - & - & - & - \\
\hline & & 37 & + & + & + & - & - & - & - & - & - & $\ldots$ & - & -- & - \\
\hline \multirow{2}{*}{ "I } & \multirow{2}{*}{ B } & $14-1$ & + & + & + & + & + & + & - & - & - & - & - & - & - \\
\hline & & 37 & + & + & + & + & + & - & -. & - & - & - & - & - & - \\
\hline & & $14-1$ & + & + & + & + & + & + & - & - & - & - & - & - & - \\
\hline & 4 & 37 & + & + & + & + & + &.- & - & - & - & - & - & - & - \\
\hline
\end{tabular}

第 5 表 調製第21日二混和セ普通大晹菌

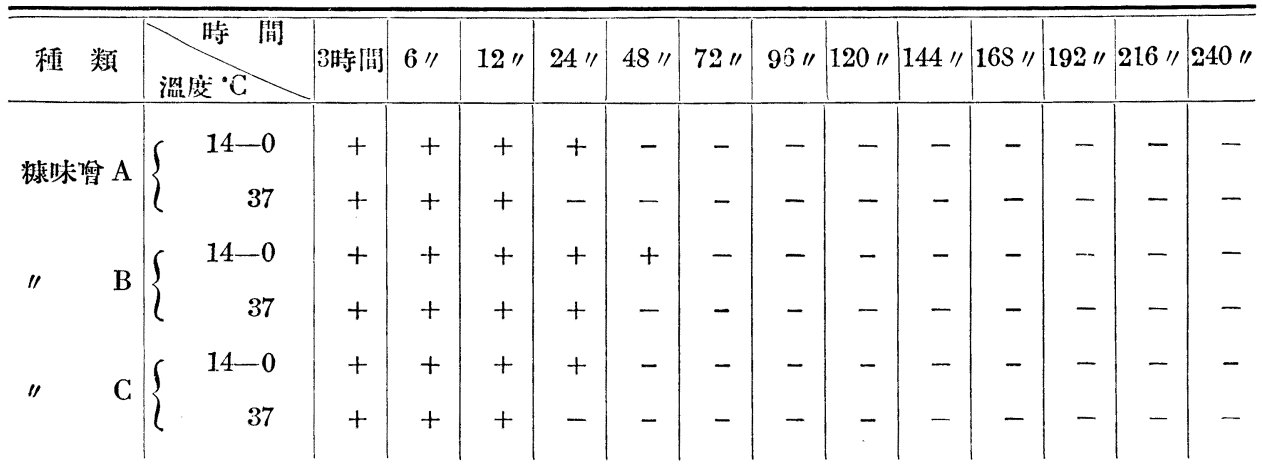

2，ちふす菌

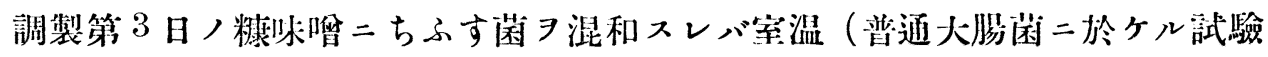

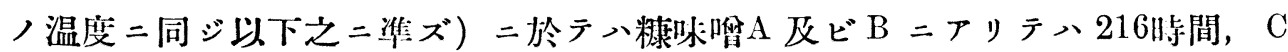

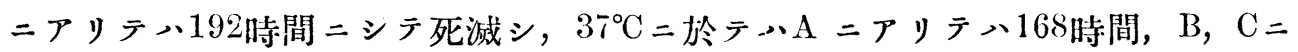
アリテハ144時間ニシテ死滅ス. 調製第7日二混和スレバ室温二保ツトキ $\mathrm{A}=ア$

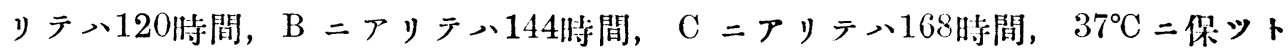
キ $\mathrm{A}$ 及ビ $\mathrm{C}=$ 及テハ 48 時間， $\mathrm{B} ニ ア リ テ ハ 72$ 時間ニシテ死減ス。調製第 14 日

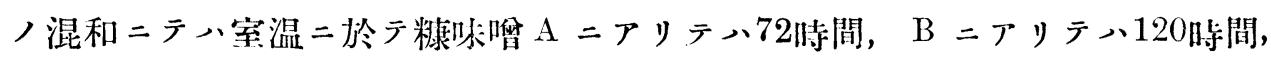

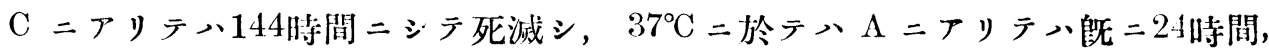
$\mathrm{B}$ 及ビ $\mathrm{C}=$ アリテ 48 時間ニシテ死滅ス。調製第 21 日ニテハ, 窑温二保ツトキ $\mathrm{A}, \mathrm{C}=$ アリテハ何レモ48時間, $\mathrm{B}=$ アリテハ72月矤間, $37^{\circ} \mathrm{C}=$ 保ツトキ $\mathrm{A}$ 及ビ

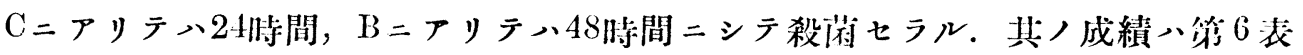


乃至第 9 非二示スガ姆シ.

第 6 表 調製第 3 日二混和セルちふす菌

\begin{tabular}{l}
\hline 種 類 \\
溫度 $\mathrm{C}^{\circ} \mathrm{C}$
\end{tabular}

第 7 表 調製第 7 日二混和七ルちふす菌

\begin{tabular}{l}
\hline 種 類 \\
\hline
\end{tabular}

第 8 表 調製籘14日二混和セルちふす菌

\begin{tabular}{l}
\hline \hline 種数 \\
\hline 溫度 ${ }^{\circ} \mathrm{C}$
\end{tabular}


第 9 表 調製第21日二混和セルちふす菌

\begin{tabular}{l}
\hline 種 類 \\
\hline 湍度 ${ }^{\circ} \mathrm{C}$
\end{tabular}

3 ぱらちふすA菌

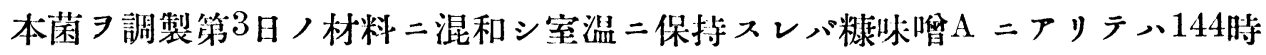
間， $\mathrm{B}=$ アテハ 120 時間， $\mathrm{C}=$ アリテ $、 96$ 時間ニシテ死隇シ， $37^{\circ} \mathrm{C}=$ 於テメ $\mathrm{A}=$ ソリテハ120時間， $\mathrm{B}$ 及ビ $\mathrm{C}=$ 及テハ何レモ96時問ニシテ死減ス。調製 第 7 日二於テハ, 室温二保ツトキ $\mathrm{A}$ 及ビ $\mathrm{B}=$ アリテハ48時間， $\mathrm{C}=$ リテハ96 時間, $37^{\circ} \mathrm{C}$ 二保ツトキ $\mathrm{A}, \mathrm{B}, \mathrm{C}=$ アリテハ何レモ48時間ニシテ死隇スベシ. 又

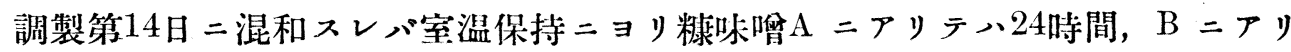
テハ 72 時間, $\mathrm{C}=\boldsymbol{ア リ テ ハ ~} 96$ 時間, $37^{\circ} \mathrm{C}=$ 於テ $\mathrm{A}=$ リテハ 24 時間, $\mathrm{B}=$ リ テハ48時間， $\mathrm{C}=$ テテハ24時間ニシテ死滅ス。調製第 21 日二混和セル場合、

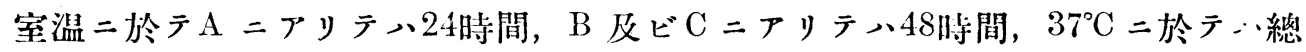

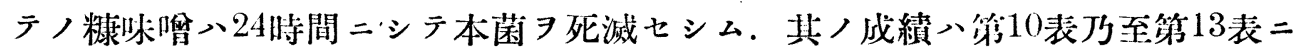
示スガ如シ.

第 10 表 調製第 3 日二混和セルばらちふすA䒩

\begin{tabular}{|c|c|c|c|c|c|c|c|c|c|c|c|c|c|c|}
\hline 種 類 & 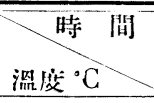 & 3時問 & $6 " \prime$ & $12 \prime \prime$ & $24 \prime \prime$ & $48 " \prime$ & $72 "$ & $96 "$ & $120 "$ & $144 "$ & $168 " \prime$ & $192 "$ & $216 "$ & $240 "$ \\
\hline \multirow{2}{*}{ 棣味賏 $\mathrm{A}$} & $14-3$ & + & + & + & + & + & + & + & + & - & - & - & - & - \\
\hline & 37 & + & + & + & + & + & + & + & - & - & - & - & - & - \\
\hline \multirow{2}{*}{ " } & $14-3$ & + & + & + & + & + & + & + & - & - & - & - & - & - \\
\hline & 37 & + & + & + & + & + & + & - & - & - & - & - & - & - \\
\hline \multirow{2}{*}{ " } & $14-3$ & + & + & + & + & + & + & - & - & - & - & - & - & - \\
\hline & 37 & + & + & + & + & + & + & - & - & - & - & - & - & - \\
\hline
\end{tabular}




$$
\text { 伊庭吉雄述 }
$$

第 11 表 調製第 3 日二混和セルぱらちふす $\mathrm{A}$ 菌

\begin{tabular}{|c|c|c|c|c|c|c|c|c|c|c|c|c|c|c|c|}
\hline 種 & 類 & 時 間 & 3時間 & $6 \prime \prime$ & $12 \prime$ & $24 \prime \prime$ & $48 \prime \prime$ & $72 \prime$ & $96 "$ & $120 "$ & $144 "$ & 168 & $192 \prime \prime$ & $216 "$ & $240 " \prime$ \\
\hline \multirow{2}{*}{ 㾧味嘫 } & & $13-1$ & + & + & + & + & - & - & - & - & - & - & - & - & - \\
\hline & & 37 & + & + & + & + & - & - & - & - & - & - & - & - & - \\
\hline \multirow{2}{*}{ "I } & \multirow{2}{*}{ B } & $13-1$ & + & + & + & + & - & - & - & - & - & - & - & - & - \\
\hline & & 37 & + & + & + & + & - & - & - & - & - & - & - & - & - \\
\hline \multirow{2}{*}{ " } & $\mathrm{C}$ & $13-1$ & + & + & + & + & + & + & - & - & - & - & - & - & - \\
\hline & & 37 & + & + & + & + & - & - & - & - & - & - & - & - & - \\
\hline
\end{tabular}

第 12 表 調製第14日二混和セルぱらちふすA菌

\begin{tabular}{l}
\hline \hline 種類 \\
\hline 温度 ${ }^{\circ} \mathrm{C}$
\end{tabular}

第 13 表 調製第 21 日二混和セルばらちふすA菌

\begin{tabular}{l}
\hline \hline 種類 \\
\hline 溫废 ${ }^{\circ} \mathrm{C}$
\end{tabular}

4,ぱらちふす B菌 


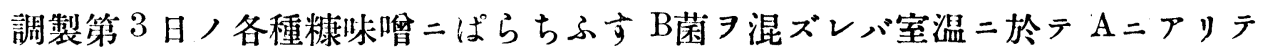
ハ216時間, $\mathrm{B}$ 及ビ $\mathrm{C}=$ アリテハ何レモ192時間, $37^{\circ} \mathrm{C}=$ 於テ $\mathrm{A}$ 及ビ $\mathrm{C}=$ アリテ ハ144時間, $\mathrm{B}=ア リ テ ハ 120$ 時間ニシテ死隇ス. 調製第 7 日二於テ室温放置二 ヨリ $\mathrm{A}=ア リ テ ハ 120$ 時間, $\mathrm{B}=$ アリテハ168時間, $\mathrm{C}=ア リ テ ハ 192$ 時間, $37^{\circ} \mathrm{C}$ ニ於テ $\mathrm{A}=$ アリテハ72時間， $\mathrm{B}$ 站二 $\mathrm{C}=$ アリテハ 96 時間ニシテ何レモ死隇メ.

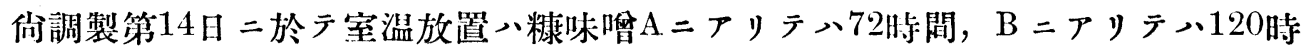
間， $\mathrm{C}=$ アンテハ 96 時間ニシテ死減シ， $37^{\circ} \mathrm{C}=$ 保ットキハ $\mathrm{A}=$ アテテ 48 時間,

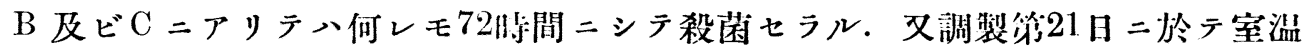

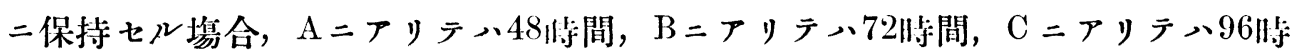

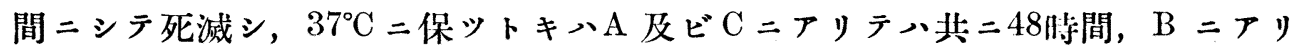
テハ72時間 ニシテ死隇ス。其ノ成績、第 14 裴乃至第 17 表二示スガ如シ.

第 14 表 調製第 3 日二混和セルばらちふす B莉

\begin{tabular}{l}
\hline \hline 種 類 \\
\hline 溫度 ${ }^{\circ} \mathrm{C}$
\end{tabular}

第 15 表 調製第7日二混和セルばらちふす B菌

\begin{tabular}{c}
\hline 種 類 \\
溫废 ${ }^{\circ} \mathrm{C}$
\end{tabular}


第 16 表 潤製第 14 日二混和セルばらちふす $\mathrm{B}$ 菌

\begin{tabular}{|c|c|c|c|c|c|c|c|c|c|c|c|c|c|c|c|}
\hline 種 & 類 & 淰度 ${ }^{\circ} \mathrm{C}$ & 3時間 & $6 \prime \prime$ & $12 \prime$ & $24 \prime \prime$ & $48 \prime \prime$ & $72 " \prime$ & $96 " \prime$ & $120 \prime \prime$ & $144 \prime \prime$ & 168 & $192 \prime$ & $216 " \prime$ & $240 \prime \prime$ \\
\hline \multirow{2}{*}{\multicolumn{2}{|c|}{ 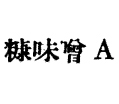 }} & $14-1$ & + & + & + & + & + & - & - & - & - & - & - & - & - \\
\hline & & 37 & + & + & + & + & - & - & - & - & - & - & - & - & - \\
\hline \multirow{2}{*}{11} & \multirow{2}{*}{ B } & $14-1$ & + & + & + & + & + & + & + & - & - & - & - & - & - \\
\hline & & 37 & + & + & + & + & + & - & - & - & - & - & - & - & - \\
\hline \multirow{2}{*}{ "I } & C & $14-1$ & + & + & + & + & + & + & - & - & - & - & - & - & - \\
\hline & & 37 & + & + & + & + & + & - & - & - & - & - & - & - & - \\
\hline
\end{tabular}

第 17 表 調製第21日二混和セルぱらちふす B菌

\begin{tabular}{l}
\hline \hline 種 類 \\
\hline
\end{tabular}

5, 志賀赤痢菌

調製第 3 日二志賀赤㢉菌 3 混和スレバ室温放置ニヨリ糠味噌 $\mathrm{A}$ 站 $=\mathrm{C} ニ ア リ$ テハ何レモ144時間， $\mathrm{B}=$ アテハ168時間, $37^{\circ} \mathrm{C}$ 二於テ $\mathrm{A}=$ アリテハ144㭙間,

$\mathrm{B}$ 站 ニョリ $\mathrm{A}$ 及ビ $\mathrm{B}=$ アリテハ 96 時間, $\mathrm{C}=$ アリテ 120 時間, $37^{\circ} \mathrm{C}=$ 於テ $\mathrm{A}=ア リ$

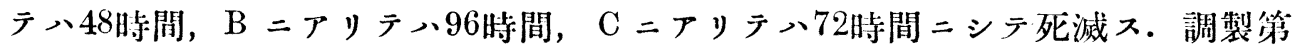

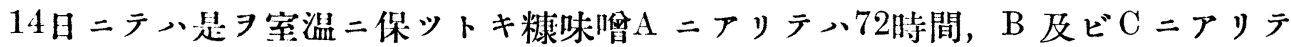

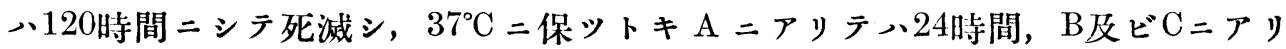
テハ何レモ48時間ニシテ死隇ス. 又調製第 21 日二混和シ室温二保持スレパ $\mathrm{A}=$ アリテハ 48 時間, $\mathrm{B}=ア リ テ ハ 96$ 時間, $\mathrm{C}=$ アリテハ 72 時間ニシテ死隇シ, $37^{\circ} \mathrm{C}$ ニ保テバA，B，Cニアリテ何レモ共ニ24時間ニシテ死隇スベシ. 其ノ成績八第 
(1500)

18乃表至第21表二示スガ如シ.

第 18 表 調製第 3 日二混和セル志賀赤痢菌

\begin{tabular}{|c|c|c|c|c|c|c|c|c|c|c|c|c|c|c|}
\hline 種 類 & 茂度 ${ }^{\circ} \mathrm{C}$ & 3時間 & $6^{\prime \prime}$ & $12 \prime \prime$ & $24 \prime \prime$ & $49 \prime \prime$ & $72 \prime \prime$ & $93 \prime$ & $120 \prime \prime$ & $144 " \prime$ & $168 \prime \prime$ & $192 !$ & $216 "$ & $240 \prime \prime$ \\
\hline \multirow{2}{*}{ 槺味嘴 $\mathrm{A}$} & $\int \quad 14-3$ & + & + & + & + & + & + & + & + & - & - & - & - & - \\
\hline & 37 & + & + & + & + & + & + & + & + & - & - & - & - & - \\
\hline "I & $\int 14-3$ & + & + & + & + & + & + & + & + & + & - & - & - & - \\
\hline & 37 & + & + & + & + & + & + & + & - & - & - & - & - & - \\
\hline \multirow{2}{*}{ "I } & $\{14-3$ & + & + & + & + & + & + & + & + & - & - & - & - & - \\
\hline & 37 & + & + & + & + & + & + & + & - & - & - & - & - & - \\
\hline
\end{tabular}

第 19 表 調製第 7 日二混和セル志賀赤痱菌

\begin{tabular}{|c|c|c|c|c|c|c|c|c|c|c|c|c|c|c|}
\hline 種 類 & 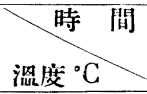 & 3時間 & $6 \prime \prime$ & $12 \prime \prime$ & $24 \prime \prime$ & $48 \prime \prime$ & $72 " 1$ & $96 \prime \prime$ & $120 \prime$ & $144 \prime \prime$ & $168 \prime$ & $192 \prime$ & $216 \prime \prime$ & $240 \prime \prime$ \\
\hline \multirow{2}{*}{ 棣味算 A } & $13-1$ & + & + & + & + & + & + & - & - & - & - & - & - & - \\
\hline & l $\quad 37$ & + & + & + & + & - & - & - & - & - & - & - & - & - \\
\hline \multirow{2}{*}{ "I $\quad$ B } & $13-1$ & + & + & + & + & + & + & - & - & - & - & - & - & - \\
\hline & 37 & + & + & + & + & + & + & - & - & - & - & - & - & - \\
\hline \multirow{2}{*}{ " $\mathrm{C}$} & $13-1$ & + & + & + & + & + & + & + & - & - & - & - & - & - \\
\hline & 37 & + & + & + & + & + & - & - & - & - & - & - & - & - \\
\hline
\end{tabular}

第 20 表 調製第 14 日二混和セル志賀赤痢菌

\begin{tabular}{l}
\hline 種 類 \\
\hline 溫度 ${ }^{\circ} \mathrm{C}$
\end{tabular}


第 21 表 調製第21日二混和セル志賀赤痢菌

\begin{tabular}{|c|c|c|c|c|c|c|c|c|c|c|c|c|c|c|c|}
\hline 種 类 & 類 & 晿废 ${ }^{\circ} \mathrm{C}$ & 3時間 & $6 " 1$ & $12^{\prime \prime}$ & $24 \prime \prime$ & $48 \prime \prime$ & $72 "$ & $96 "$ & $12 J " 1$ & $144 \prime \prime$ & 168 & $192 "$ & $216 \prime \prime$ & $240 \prime \prime$ \\
\hline \multirow{2}{*}{\multicolumn{2}{|c|}{ 棣味筫 $\mathrm{A}$}} & $14-0$ & + & + & + & + & - & - & - & - & - & - & - & - & - \\
\hline & & 37 & + & + & + & - & - & - & - & - & - & - & - & - & - \\
\hline \multirow{2}{*}{ "I } & B & $14-0$ & + & + & + & + & + & + & - & - & - & - & - & - & - \\
\hline & & 37 & + & + & + & - & - & - & - & - & - & - & - & - & - \\
\hline \multirow{2}{*}{ " } & C & $14-0$ & + & + & + & + & + & - & - & - & - & - & - & - & - \\
\hline & & 37 & + & + & + & - & - & - & - & - & - & - & - & - & - \\
\hline
\end{tabular}

6, これら菌

調製第 3 日ノ糠味嚊ニこれら菌 何レモ60分後二ハ之ガ生存 7 證明スルモ既二 3 洔間 7 經ルニ及ンデ全然死滅シ $37^{\circ} \mathrm{C}$ 二於ティ $\mathrm{B}=$ アリティ30分, $\mathrm{A}$ 及ビ $\mathrm{C}=$ アリテハ60分ニシテ死隇ス. 調製 第 7 日二於テ室温二保持スル㙫合, $\mathrm{A}=$ アリテハ5分, $\mathrm{B}$ 及ビ $\mathrm{C}=$ アリテハ30分 間 生命 7 維持シ, $37^{\circ} \mathrm{C}$ 二保ツトキハ $\mathrm{A}=$ アリテハ5分, $\mathrm{B}$ 及ビ $\mathrm{C}=$ アリテ 10 分ニシテ死隇ス. 調製第 14 日二混和スルトキ, $37^{\circ} \mathrm{C}=$ 保持スレバ $\mathrm{A}, \mathrm{B}, \mathrm{C}=$ アリテ5分後二、生存セズ, 室温二於テ、 $\mathrm{B}=$ アリテハ10分後, $\mathrm{C}=$ アリテハ 15分後们生存ス。調製第21日二於ヶルモノハ何レノ糠味賴ニモこれら菌ノ生存 ヨ許ルサズ, 其ノ成績、第22表乃至第25表二示スガ如シ.

第 22 表 調製第 3 日二混和セルこれら菌

\begin{tabular}{|c|c|c|c|c|c|c|c|c|c|c|c|c|c|c|c|}
\hline 種 & 数 & $\begin{array}{l}\text { 時 間 } \\
\text { 溫度 }{ }^{\circ} \mathrm{C}\end{array}$ & 5分 & $10 "$ & $15 \prime$ & $30 "$ & 1時間 & $3 \prime \prime$ & $6 " 1$ & $12 " \prime$ & $24 \prime \prime$ & $48 \prime \prime$ & $72 \prime \prime$ & $96 "$ & $120 " \prime$ \\
\hline \multirow{2}{*}{ 棣味嘫 } & & $14-3$ & + & + & + & + & + & - & $=$ & - & - & - & - & - & - \\
\hline & & 37 & + & + & + & + & - & - & - & - & - & - & - & - & - \\
\hline \multirow{2}{*}{ "I } & \multirow{2}{*}{ B } & $14-3$ & + & + & + & $++^{\circ}$ & + & - & - & - & - & - & - & - & - \\
\hline & & 37 & + & + & + & - & - & - & - & - & - & - & - & - & - \\
\hline \multirow{2}{*}{ "I } & C & $14-3$ & + & + & + & + & + & - & - & - & - & - & - & - & - \\
\hline & & 37 & + & + & + & + & - & - & - & - & - & - & - & - & - \\
\hline
\end{tabular}

第 23 表 調製第7 日二混和セルこれら菌 


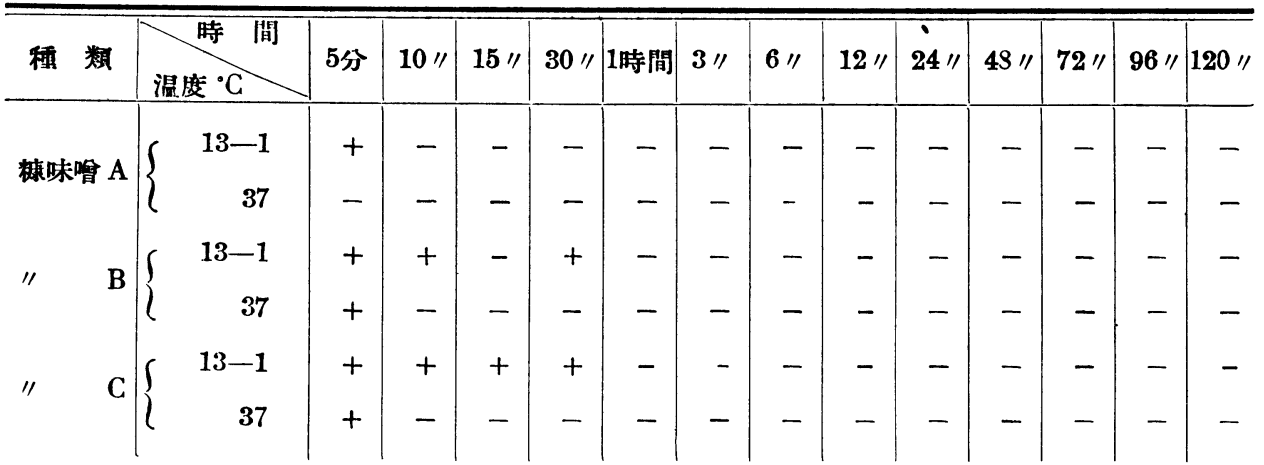

第 24 表 第 14 日二混和セルこれら菌

\begin{tabular}{|c|c|c|c|c|c|c|c|c|c|c|c|c|c|c|c|}
\hline 種 & & 暏度 & 5分 & $10 \prime$ & $15 "$ & $30 \prime \prime$ & 1時間 & $3 \prime$ & $6 " 1$ & $12 "$ & $24 \prime \prime$ & $48 \prime \prime$ & $72 \prime$ & $96 "$ & $120 \prime$ \\
\hline \multirow{2}{*}{\multicolumn{2}{|c|}{ 槺味嘫 }} & $14-1$ & - & - & - & - & - & - & - & - & - & - & - & - & - \\
\hline & & 37 & - & - & - & - & - & - & - & - & - & - & - & - & - \\
\hline \multirow{2}{*}{ "I } & \multirow{2}{*}{ B } & $14-1$ & + & + & - & - & - & - & - & - & - & - & - & - & - \\
\hline & & 37 & - & - & - & - & - & - & - & - & - & - & - & - & - \\
\hline & $C$ & $14-1$ & + & + & + & - & - & - & - & - & - & - & - & - & - \\
\hline & & 37 & - & - & - & - & - & - & - & - & - & - & - & - & - \\
\hline
\end{tabular}

第 25 表 調製第 21 日二混和セルこれら菌

\begin{tabular}{|c|c|c|c|c|c|c|c|c|c|c|c|c|c|c|c|}
\hline 棰 & 類 & 淡度·C & 5分 & $10 "$ & $15 "$ & $30 \prime$ & 1時間 & $3 \prime \prime$ & $6 " 1$ & $12 \prime \prime$ & $24 \prime \prime$ & $48 \prime \prime$ & $72 \prime \prime$ & $96 "$ & $120 "$ \\
\hline \multirow{2}{*}{ 渋味管 } & & $14-0$ & - & & - & - & - & - & - & - & - & - & - & - & \\
\hline & & 37 & - & - & - & - & - & - & - & - & - & - & - & - & - \\
\hline \multirow{2}{*}{ "I } & B & $14-0$ & - & - & - & - & - & - & - & - & - & - & - & - & - \\
\hline & & 37 & - & - & - & - & $\tau$ & - & - & - & - & - & - & - & - \\
\hline \multirow{2}{*}{ "I } & $C$ & $14-0$ & - & - & - & - & - & - & - & - & - & - & - & - & - \\
\hline & & 37 & - & - & - & - & - & - & - & - & - & - & - & - & - \\
\hline
\end{tabular}

普通大腸菌, ちふす菌，ぱらちふす A菌，ばらちふす B 菌，志賀型赤痢菌及 
ビこれら菌い余ノ調製セル3種ノ實驗用糠味噃中二於テ早晚死隇ノ運命 リ, 即于 糠味唄ハ消化器傳染病病原菌二對シテ殺菌力シ有スルコトハ事實ナ リ.

糠味䁚二混和セル是等諸菌ノ抵抗力ハこれら菌最モ弱ク，爾稌ノ5菌株ハこ れら菌二比シテ抵抗稍々强ク生存期間 ノ條件ニョリ生存期間一定セズ. 即チ同一糠味嗊二於ヶル殺菌力二就テ考フル モ, 調製後日仯淺キもノ二弱ク, 日ヨ經タルモノ二强シ, 而シテ撥酵ノ進行ト

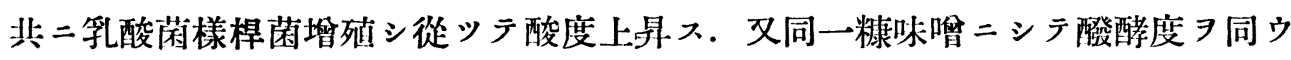
スルモノニアリテハ之ヨ低温二保持スルョリモ $37^{\circ} \mathrm{C}$ 二保ツ方殺菌力强大ナリ, 而シテ $37^{\circ} \mathrm{C}$ ノ如ク高温二保ツトキハ乳酸菌樣桿菌ノ增殖 助長セシム. 次二酸度略同等ニシテ食監含有量 $\ni$ 異ニスル2種ノ糠味嗊 $习$ 同温 度二保ツトキ屢々食監含有量大ナル方殺菌力强キ結果ヨ認ム。

\section{第 2 章 滅菌槺味哈二混和スル消化器 傳染病病原菌ノ運命二就テ 第 1 匴 供試材料竝二檢查方法}

前章琠驗二於テ糠味骝二混和セル消化器傳染病病原諸菌ハ早晚殺菌セラレ, 其ノ殺菌力八總酸度，食監含有量及ビ温度二影響スルコトア知り得タリ。余入

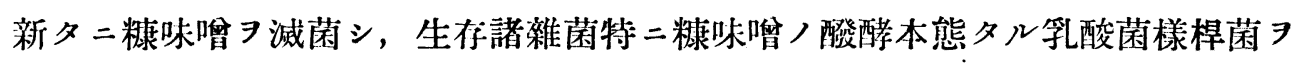
死隇セシヌ, 之二消化器傅染病病原菌

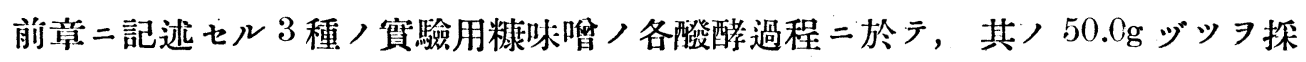
リ蒸泉釜二テ 2 時間惹沸隇菌シ, 菌浸滛がーせ拆入方法ニョリテ試驗セリ, 们 隇菌糠味噌ノ壓控濾過液二於ヶル水素いおん濃度、非隇菌糠味䁚ノ夫レ二比シ

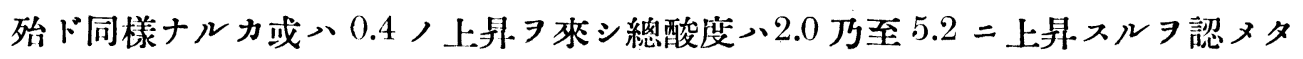
リ.

\section{第 2 節 寅 臨 成 績}

1, 普通大腸菌

調製第3 日ノ糠味骝 $コ$ 隇菌シ普通大腸菌 3 混和シタルニ室温（攝氏 $14^{\circ} \mathrm{C}$ 乃至 
$\left.3^{\circ} \mathrm{C}\right)$ 二於テ糠味稩 $\mathrm{A}=ア リ テ ハ 192$ 時間, $\mathrm{B}=$ アリテハ 144 時間, $\mathrm{C}=$ アリテハ 120 時間, $37^{\circ} \mathrm{C}$ 二於テ $\mathrm{A}, \mathrm{B}=$ アリテハ夫々 72 時間, $\mathrm{C}=$ アリテハ48時間ニシテ死 滅ス。第7日ノ混和二於テ室温 $\left(13^{\circ} \mathrm{C}\right.$ 乃至 $\left.1^{\circ} \mathrm{C}\right)=$ テ $\mathrm{A}=$ ソテハ72時間, $B=$ アリティ96時間, $\mathrm{C}=$ アリテハ 144 時間, $37^{\circ} \mathrm{C}=$ テ $\mathrm{A}=$ アテハ48時間, $\mathrm{B}=$ アリテハ96時間， $\mathrm{C}=$ アリテハ24時間ニシテ死隇ス。調製第14日二於テハ室温

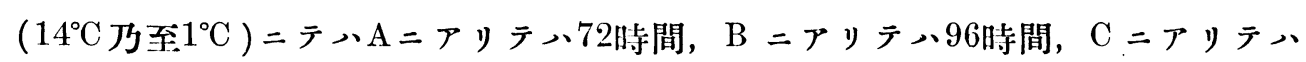
120 時間 ニシテ死隇スベシ, 又 $37^{\circ} \mathrm{C}=$ 於テハ $\mathrm{A}$ 及ビ $\mathrm{C}=$ アテハ 24 時間, $\mathrm{B}=\boldsymbol{\gamma}$ リテ $\cdots 48$ 時間ニシテ死隇ス。調製第 21 日二於テ室温 $\left(14^{\circ} \mathrm{C}\right.$ 乃至零度 $)=テ ッ \mathrm{~A}$

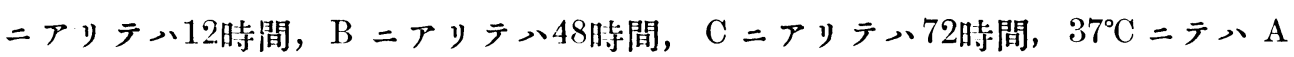

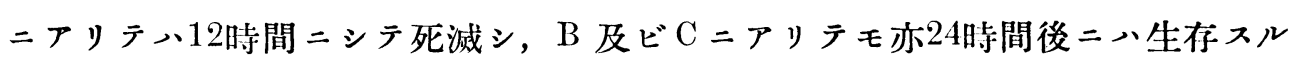
ヨ得ズ，其ノ成績ハ第26表乃至第29表二示スガ如シ.

第 26 表 調製第3日ノ滅莉糠味㲘二混和セル普通大晹菌

\begin{tabular}{l}
\hline 種類 \\
\hline 溫度 ${ }^{\circ} \mathrm{C}$
\end{tabular}

第 27 表 調製第 7 日ノ隇菌糠味筥二混和セル普通大腸菌

\begin{tabular}{l|}
\hline 種 類 \\
\hline 温度 ${ }^{\circ} \mathrm{C}$
\end{tabular}


第 28 表 調製第 14 日 ノ隇菌糠味㗍二混和セル普通大腸菌

\begin{tabular}{|c|c|c|c|c|c|c|c|c|c|c|c|c|c|c|}
\hline 種 類 & 時 成 & 3時閑 & $6 \prime \prime$ & $12 \prime$ & $24 \prime \prime$ & $48 \prime \prime$ & $72 \prime \prime$ & $96 \prime \prime$ & $120 \prime \prime$ & $144 \prime \prime$ & $168 \prime \prime$ & $1.92 \prime$ & $216 \prime$ & $240 \prime \prime$ \\
\hline \multirow{2}{*}{ 槺味简 A } & $14-1$ & + & + & + & + & + & - & - & - & - & - & - & - & - \\
\hline & 37 & + & + & + & - & - & - & - & - & - & - & - & - & - \\
\hline \multirow{2}{*}{ "1 } & $\int 14-1$ & + & + & + & + & + & + & - & - & - & - & - & - & - \\
\hline & 37 & + & + & + & + & - & - & - & - & - & - & - & - & - \\
\hline \multirow{2}{*}{ "I } & $\int 14-1$ & + & + & + & + & + & + & + & - & - & - & - & - & - \\
\hline & 87 & + & + & + & - & - & - & - & - & - & - & - & - & - \\
\hline
\end{tabular}

第 29 表 調製第21日ノ隇菌糠味䁚二混和セル普通大腸菌

\begin{tabular}{|c|c|c|c|c|c|c|c|c|c|c|c|c|c|c|}
\hline 粫 類 & 時 间 & 3時間 & $6 " \prime$ & $12 \prime$ & $24 \prime \prime$ & $48 \prime \prime$ & $72 \prime \prime$ & $96 \prime \prime$ & $1.20 \prime \prime$ & $144 \prime \prime$ & $168 \prime$ & $192 \prime \prime$ & $216 \prime$ & $240 " \prime$ \\
\hline \multirow{2}{*}{ 樜味嘫 A } & $14-0$ & + & + & - & - & - & - & - & - & - & - & - & - & - \\
\hline & $l \quad 37$ & + & + & - & - & - & - & - & - & - & - & - & - & - \\
\hline \multirow{2}{*}{ " $\quad \mathrm{B}$} & ( $14-0$ & + & + & + & + & - & - & - & - & - & - & - & - & - \\
\hline & 37 & + & + & + & - & - & - & - & - & - & - & - & - & - \\
\hline \multirow{2}{*}{ "1 } & $14-0$ & + & + & + & + & + & - & - & - & - & - & - & - & - \\
\hline & 37 & + & + & + & - & - & - & - & - & - & - & - & - & - \\
\hline
\end{tabular}

2, ちふす菌

調製第 3 日ノ糠味骝二於テ室温放置ニョリ $\mathrm{A} ニ ア リ テ ハ 216$ 時間, $\mathrm{B}$ 及ビ $\mathrm{C}=$ アリテハ 192 時間, $37^{\circ} \mathrm{C}=$ テハ $\mathrm{A}=$ アリテハ96時間， $\mathrm{B}$ 及ビ $\mathrm{C}=$ アリテハ何レモ 48時間ニシテ死隇ス。調製第 7 日ノモノニ就テ、室温ニテハ $A=ア リ テ ハ 96$ 時

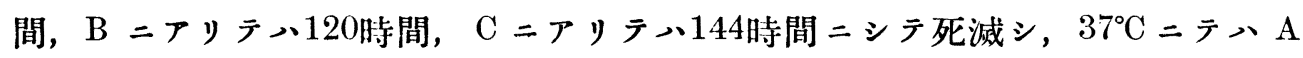
ニアリテハ 24 時間, $\mathrm{B}=$ アテテハ72時間, $\mathrm{C}=$ アリテハ48時間ニシテ死滅ス.

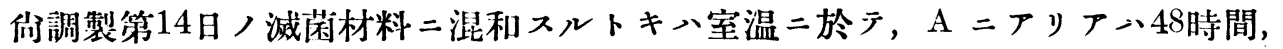

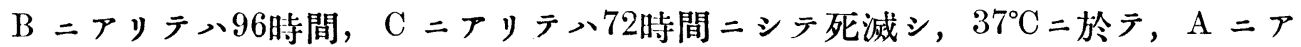
リテハ 12 時間， $\mathrm{B}$ 站 $=\mathrm{C}=ア リ テ ハ 24$ 時間ニシテ死隇ス. 又調製第 21 日二於ケ

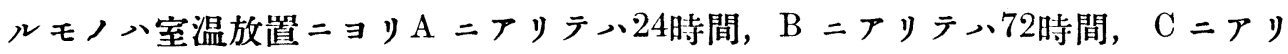

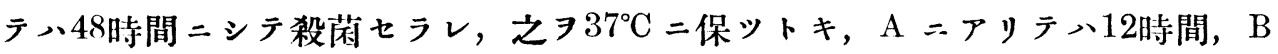


(1506)

及ビ $\mathrm{C}=$ ンテハ 24 時間ニシテ死隇シタリ. 其ノ成績ハ第30表乃至第 33 表二示 スガ如シ.

第 30 表 調製第 3 日ノ減菌糠味嗊二混利セルちふす菌

\begin{tabular}{l}
\hline 種 類 \\
\hline 溫度 ${ }^{\circ} \mathrm{C}$
\end{tabular}

第 31 表 調製第 7 日ノ滅菌糠味㴰二混利セルちふす菌

\begin{tabular}{|c|c|c|c|c|c|c|c|c|c|c|c|c|c|c|c|}
\hline 種 & 類 & 時 間 & 3時間 & $6 " 1$ & $12 \prime$ & $24 \prime \prime$ & $48 "$ & $72 \prime \prime$ & $96 "$ & $120 "$ & $144 \prime \prime$ & $168 "$ & $192 "$ & $216 "$ & $24^{\prime \prime} \prime \prime$ \\
\hline \multirow{2}{*}{\multicolumn{2}{|c|}{ 棣味唓 $\mathrm{A}$}} & $13-1$ & + & + & + & + & + & + & - & - & - & - & - & - & _ \\
\hline & & 37 & + & + & + & - & - & - & - & - & - & - & - & - & - \\
\hline \multirow{2}{*}{ "I } & B & $13-1$ & + & + & + & + & + & + & + & - & - & - & - & - & - \\
\hline & & 37 & + & + & + & + & + & - & - & - & - & - & - & - & - \\
\hline \multirow[t]{2}{*}{ "I } & C & $13-1$ & + & + & + & + & + & + & + & + & - & - & - & - & - \\
\hline & & 37 & + & + & + & + & - & - & - & - & - & - & - & - & - \\
\hline
\end{tabular}

第 32 表 調製第 14 日ノ隇菌糠味嘅二混和セルちふす蔺

\begin{tabular}{|c|c|c|c|c|c|c|c|c|c|c|c|c|c|c|c|}
\hline 種 & 数 & 溫度 ${ }^{\circ} \mathrm{C}$ & 3時間 & $6 " 1$ & $12 " \prime$ & $24 \prime \prime$ & $48 "$ & $72 " \prime$ & $96 "$ & $120 "$ & $144 \prime$ & $163 "$ & $192 "$ & $216 "$ & $\mid 240 \prime$ \\
\hline \multirow{2}{*}{ 梂味毄 } & & $14-1$ & + & + & + & + & - & - & - & - & - & - & - & - & - \\
\hline & & 37 & + & + & - & - & - & - & - & - & - & - & - & - & - \\
\hline \multirow{2}{*}{ "I } & \multirow{2}{*}{ B } & $14-1$ & + & + & + & + & + & + & - & - & - & - & - & - & - \\
\hline & & 37 & + & + & + & - & - & - & - & -- & - & - & - & - & - \\
\hline \multirow{2}{*}{ "I } & $C$ & $14-1$ & + & + & + & + & + & - & - & - & - & - & - & - & - \\
\hline & & 37 & + & + & + & - & - & - &. & - & - & - & - & - & - \\
\hline
\end{tabular}




$$
\text { 作庭吉雄述 }
$$

第 33 表 調製第21日ノ滅荣糠味噌二混和セルちふす菌

\begin{tabular}{|c|c|c|c|c|c|c|c|c|c|c|c|c|c|c|c|}
\hline 種 & 類 & 溫度 ${ }^{\circ} \mathrm{C}$ & 3時開 & $6 " 1$ & $12 "$ & $24 \prime \prime$ & $48 \prime \prime$ & $72 \prime$ & $96 "$ & $120 \prime \prime$ & 144 " & $163 "$ & $192 "$ & $216 "$ & $240 \prime \prime$ \\
\hline \multirow{2}{*}{ 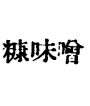 } & $A$ & $14-0$ & + & + & + & - & - & - & - & - & - & - & - & - & - \\
\hline & & 37 & + & + & - & - & - & - & - & - & - & - & - & - & - \\
\hline \multirow{2}{*}{ "1 } & $\mathbf{R}$ & $14-0$ & + & + & + & + & + & - & - & - & - & - & - & - & - \\
\hline & & 87 & + & + & + & - & - & - & - & - & - & - & - & - & - \\
\hline \multirow{2}{*}{ "1 } & 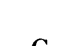 & $14-0$ & + & + & + & + & - & - & - & - & - & - & - & - & - \\
\hline & & 37 & + & + & + & - & - & - & - & - & - & - & - & - & - \\
\hline
\end{tabular}

3ばらちふすA菌

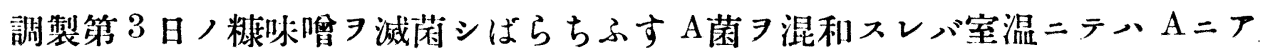
リテハ192時間， $\mathrm{B}$ 及ビ $\mathrm{C}=$ アテハ 168 時間ニシテ死隇シ， $37^{\circ} \mathrm{C}=$ テハ何レモ 48 時間ニシテ死隇ス。調製第 7 日二於テハ室温二保ッ塲合 $A=ア リ テ ハ 48$ 時 間, $\mathrm{B}$ 端 間， $\mathrm{B}$ 及ビ $\mathrm{C}$ ニアリテハ24時間ニシテ死隇ス。調製第 14 日 ニテハ室温放置二ョ リ $\mathrm{A}=$ アリテハ 48 時間, $\mathrm{B}=$ アリテハ 96 時間, $\mathrm{C}=$ アリテハ72時間ニシテ死滅 シ, $37^{\circ} \mathrm{C}=$ テ $\mathrm{A}$ 及ビ $\mathrm{C}=ア リ テ ハ 12$ 時間, $\mathrm{B}=$ アリテハ 24 時間ニシテ死隇ス.

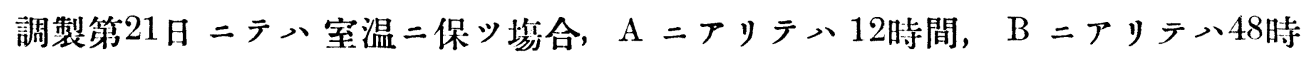
間, $\mathrm{C}=$ アリテハ 24 時間 ニシテ死隇シ，又之 $337^{\circ} \mathrm{C}=$ 保持スルトキハ $\mathrm{A}, \mathrm{B}, \mathrm{C}$ ニアリテハ何レモ12時間後ニ八生菌ヨ遺殘セズ，其ノ成績八第34表乃至第37表 二示スガ如シ:

第 34 表 調製第 3 日ノ滅菌糠味骝二混和セルぱらちふすA菌

\begin{tabular}{|c|c|c|c|c|c|c|c|c|c|c|c|c|c|c|c|}
\hline 種 & 数 & 溫度 ${ }^{\circ} \mathrm{C}$ & 3時間 & $6 " 1$ & $12 \prime$ & $24 \prime \prime$ & $48 \prime \prime$ & $72 "$ & $96 "$ & $120 "$ & 144 " & 163 & $192 \prime$ & $216 " \mid$ & $240 "$ \\
\hline \multirow{2}{*}{ 棣味湆 } & & ( $\quad 14-3$ & + & + & + & + & + & + & + & + & + & + & - & - & 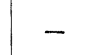 \\
\hline & & 37 & + & + & + & + & - & - & - & - & - & - & - & - & - \\
\hline \multirow{2}{*}{11} & \multirow{2}{*}{ B } & $14-3$ & + & + & + & + & + & + & + & + & + & - & - & - & - \\
\hline & & 37 & + & + & + & + & - & - & - & - & - & - & - & - & - \\
\hline & $C$ & $14-3$ & + & + & + & + & + & + & + & + & + & - & - & - & - \\
\hline & & 37 & + & + & + & + & - & - & - & - & - & - & - & - & - \\
\hline
\end{tabular}


第 35 表 調製第7日ノ滅菌糠味噌二混和セルぱらちふすA菌

\begin{tabular}{l}
\hline 種 類 \\
溫度 $\mathrm{C}$
\end{tabular}

第 36 表 調製第14日ノ滅菌糠味噃二混和セルぱらちふすA菌

\begin{tabular}{|c|c|c|c|c|c|c|c|c|c|c|c|c|c|c|}
\hline 種 類 & 時 間 $^{\text {溫㢑 }{ }^{\circ} \mathrm{C}}$ & 3時閌 & $6 " \prime$ & $12 "$ & 241 & $48 \prime$ & $72 \prime$ & $96 "$ & 120 & 144 " & ון 168 & $192 " \prime$ & 216 & $240 "$ \\
\hline \multirow{2}{*}{ 粶味噌 $\mathrm{A}$} & $14-1$ & + & + & + & + & - & - & - & - & - & - & - & - & - \\
\hline & 37 & + & + & - & - & - & - & - & - & - & - & - & - & - \\
\hline \multirow{2}{*}{ " } & $14-1$ & + & + & + & + & + & + & - & - & - & - & - & - & - \\
\hline & 37 & + & + & + & - & - & - & - & - & - & - & - & - & - \\
\hline \multirow{2}{*}{ "1 } & $14-1$ & + & + & + & + & + & - & - & - & - & - & - & - & - \\
\hline & 37 & + & + & - & - & - & - & - & - & - & - & - & - & - \\
\hline
\end{tabular}

第 37 表 調製第 21 日ノ糠味噌二混和セルばらちふすA藏

\begin{tabular}{|c|c|c|c|c|c|c|c|c|c|c|c|c|c|c|c|}
\hline 種 & & 溫度 ${ }^{\circ} \mathrm{C}$ & 30寺lii] & $6 " \prime$ & $1.2 \prime \prime$ & $24 \prime \prime$ & $48 "$ & $72 "$ & $96 "$ & $1.20 "$ & $144 \prime$ & $163 "$ & 192 & $216 "$ & $240 "$ \\
\hline \multirow{2}{*}{ 粽味䠥 } & & $14-0$ & + & + & - & - & 1 & - & - & - & - & - & - & - & - \\
\hline & & 37 & + & + & - & - & - & - & - & - & - & - & - & - & - \\
\hline \multirow{2}{*}{ "I } & \multirow{2}{*}{ B } & $14-0$ & + & + & + & + & - & - & - & - & - & - & - & - & - \\
\hline & & 37 & + & + & - & - & - & - & - & - & - & - & - & - & - \\
\hline \multirow{2}{*}{ "I } & & $14-0$ & + & + & + & - & - & - & - & - & - & - & - & - & - \\
\hline & C & 37 & + & + & - & - & - & - & - & - & - & - & - & - & - \\
\hline
\end{tabular}

4,ぱらちふすB菌 


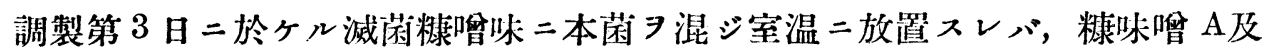
ビ $\mathrm{C}=$ アリハ 216 時間, $\mathrm{B}=$ アリテハ168時間ニシテ死滅シ，之 $337^{\circ} \mathrm{C}=$ 保ッ トキ $\mathrm{A}$ 及ビ $\mathrm{B}=$ アテハ 48 時間後遺殘スルモノアレドモ， $\mathrm{C} ニ$ アリテハ死隇ス.

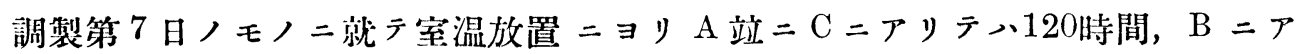
リテハ 144 時間, $37^{\circ} \mathrm{C}=$ 於テ $\mathrm{A}$ 及ビ $\mathrm{C}=$ アリテ 24 時間, $\mathrm{B}=$ アリテハ48時間二 シテ死隇ス。調製第14日ノ減菌材料二混和スルトキ, 室温二於テ $\mathrm{A}$ スアリテハ 48 時間， $\mathrm{B}$ 及ビ $\mathrm{C}=$ アリテハ 96 時間, $37^{\circ} \mathrm{C}=$ 於テ $\mathrm{A}$ 及ビ $\mathrm{C}=$ アリハ 24 時間, $\mathrm{B}$ ニアリテハ48時間ニシテ殺蔺セラル. 調製第21日二於ケル混和試驗二於テ, 室温二保ッ塲合， $\mathrm{A}=$ テリテハ24時間， $\mathrm{B}=$ アリテハ96時間， $\mathrm{C}=$ アリテハ72

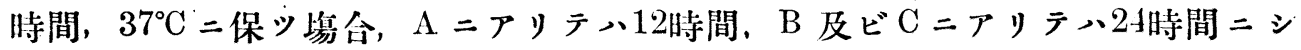
テ死滅セシム，其ノ成績八第 38 表乃至第 41 表二示スガ如シ.

第 38 表 調製第 3 日ノ滅菌糠味唄二混和セルばらちふす B菌

\begin{tabular}{|c|c|c|c|c|c|c|c|c|c|c|c|c|c|c|c|}
\hline 種 & 数 & 時 間 $^{\circ}$ & 3 時闻 & $6 \prime \prime$ & $12 \prime$ & $24 \prime \prime$ & $48 \prime \prime$ & $72 \prime \prime$ & $96 \prime$ & $12)^{\prime \prime}$ & 144 & $168 \prime$ & $192 \prime$ & 216 & $240 \prime \prime$ \\
\hline \multirow{2}{*}{\multicolumn{2}{|c|}{ 楾味嘫 A }} & $14-3$ & + & + & + & + & + & + & + & + & + & + & + & - & - \\
\hline & & 37 & + & + & + & + & + & - & - & - & - & - & - & - & - \\
\hline \multirow[t]{2}{*}{ "I } & \multirow{2}{*}{ B } & $14-3$ & + & + &. & + & + & + & + & + & + & - & - & - & - \\
\hline & & 37 & + & + & + & + & + & - & - & - & - & - & - & - & - \\
\hline \multirow{2}{*}{ "1 } & \multirow{2}{*}{ C } & $14-3$ & + & + & + & + & + & + & + & + & + & + & + & - & - \\
\hline & & 37 & + & + & + & + & - & - & - & - & - & - & - & - & - \\
\hline
\end{tabular}

第 39 表 調製第 7 日ノ減菌糠味筥二混和セルばらちふす $\mathrm{B}$ 菌

\begin{tabular}{|c|c|c|c|c|c|c|c|c|c|c|c|c|c|c|c|}
\hline 種 齐 & 類 & 溫度 ${ }^{\circ} \mathrm{C}$ & 3時間 & $6 "$ & $12 \prime \prime$ & $24 \prime \prime$ & $48 \prime \prime$ & $72 \prime \prime$ & $96 \prime \prime$ & $120 \prime \prime$ & $144 \prime \prime$ & $168 \prime \prime$ & $192 \prime \prime$ & $216 "$ & $240 \prime \prime$ \\
\hline \multirow{2}{*}{\multicolumn{2}{|c|}{ 棣味筸 A }} & $13-1$ & + & + & + & + & + & + & + & - & - & - & - & - & - \\
\hline & & 37 & + & + & + & - & - & - & - & - & - & - & - & - & - \\
\hline \multirow{2}{*}{ "I } & \multirow{2}{*}{ B } & $13-1$ & + & + & + & + & + & + & + & + & - & - & - & - & - \\
\hline & & 37 & + & + & + & + & - & - & - & - & - & - & - & - & - \\
\hline \multirow{2}{*}{11} & \multirow{2}{*}{ C } & $13-1$ & + & + & + & + & + & + & + & - & - & - & - & - & - \\
\hline & & 37 & + & + & + & - & - & - & - & - & - & - & - & - & - \\
\hline
\end{tabular}


第 40 表 調製第14日二隇菌糠味噌二混和セルぱらちふす B菌

\begin{tabular}{|c|c|c|c|c|c|c|c|c|c|c|c|c|c|c|}
\hline 種 類 & $\begin{array}{l}\text { 時 間 } \\
\text { 淰度 }{ }^{\circ} \mathrm{C} \\
\end{array}$ & 3 時間 & $6 \prime \prime$ & $12 \prime$ & $24 \prime \prime$ & $4 S^{\prime \prime}$ & $72 \prime \prime$ & $96 \prime \prime$ & $120 \prime \prime$ & $144 \prime \prime$ & $168 \prime \prime$ & $192 \prime$ & $216 "$ & $240 \prime \prime$ \\
\hline \multirow{2}{*}{ 冰味喫 A } & $14-1$ & + & + & + & + & - & - & - & - & - & - & - & - & - \\
\hline & 37 & + & + & + & - & - & - & - & - & - & - & - & - & - \\
\hline \multirow[t]{2}{*}{ "I } & $14-1$ & + & + & + & + & + & + & - & - & - & - & - & - & - \\
\hline & l $\quad 37$ & + & + & + & + & - & - & $\overline{.}$ & - & - & - & - & - & - \\
\hline & $\cdot 14-1$ & + & + & + & + & + & + & - & - & - & - & - & - & - \\
\hline & 37 & + & + & + & - & - & - & - & - & - & - & - & - & - \\
\hline
\end{tabular}

第 41 表 調製第 21 日二隇菌糠味筥二混和セルぱらちふす $\mathrm{B}$ 菌

\begin{tabular}{|c|c|c|c|c|c|c|c|c|c|c|c|c|c|c|c|}
\hline 種 & 類 & 時 & 3時間 & $6 \prime \prime$ & $12 \prime \prime$ & $24 \prime \prime$ & $48 \prime \prime$ & $72 \prime$ & $96 "$ & $120 \prime \prime$ & $144 \prime \prime$ & $1.63 \prime \prime$ & $192 \prime$ & 216 & $240 "$ \\
\hline \multirow{2}{*}{\multicolumn{2}{|c|}{ 棣味㗱 $\mathrm{A}$}} & $14-0$ & + & + & + & - & - & - & - & - & - & - & - & - & - \\
\hline & & 37 & + & + & - & - & - & - & - & - & - & - & - & - & - \\
\hline \multirow{2}{*}{ "I } & \multirow{2}{*}{ B } & $14-0$ & + & + & + & + & + & + & - & - & - & - & - & - & - \\
\hline & & 37 & + & + & + & - & - & - & - & - & - & - & - & - & - \\
\hline \multirow{2}{*}{ "I } & \multirow{2}{*}{ C } & $14--0$ & + & + & + & + & + & - & - & - & - & - & - & - & - \\
\hline & & 37 & + & + & + & - & - & - & - & - & - & - & - & - & - \\
\hline
\end{tabular}

5 , 志賀型赫痢菌

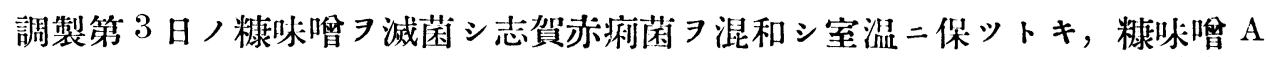
ニアリテハ192時間, $\mathrm{B}$ 及ビ $\mathrm{C}=$ アリテハ其 $=120$ 時間 ニシテ死隇シ, $37^{\circ} \mathrm{C}=$ 保 ツトキハ何レモ72月時間ニシテ死隇ス。第 7 日二於テ寀温放狊ニョリ，A=アリ

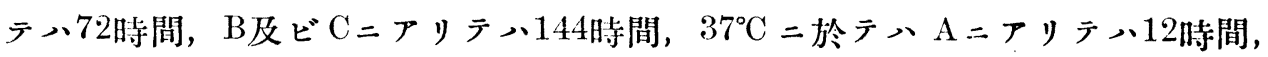

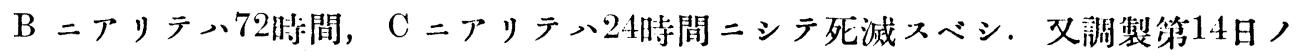

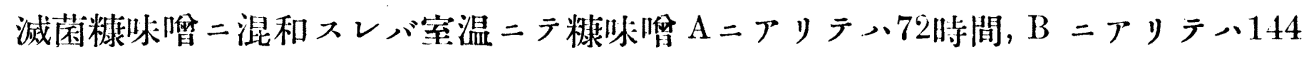
時間, $\mathrm{C}=$ アリテハ96時間, $37^{\circ} \mathrm{C}=$ 於テハ $\mathrm{A}=$ アリテハ12時間, $\mathrm{B}=$ アテテハ 48 時間, $\mathrm{C}=$ ソテハ24時間ニシテ死隇ス. 調製第21日ノモノョ以テシテハ军

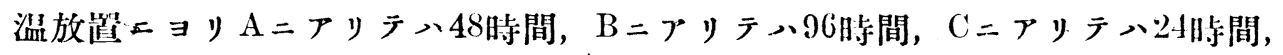




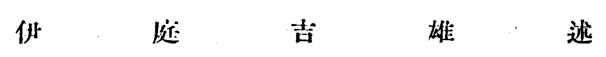

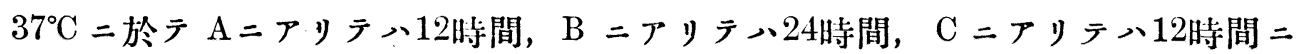
シテ死滅ス. 其ノ成績八第42表乃至第45表二示スガ如シ.

第 42 表 调製第 3 日ノ隇菌糠味嗊二混和セル志賀赤痢菌

\begin{tabular}{l}
\hline . 種類 \\
\hline 溫度 ${ }^{\circ} \mathrm{C}$
\end{tabular}

第 43 表 調製第 7 日ノ隇菌糠味嗊二混和セル志賀赤瘕菌

\begin{tabular}{|c|c|c|c|c|c|c|c|c|c|c|c|c|c|c|}
\hline 種 類 & 滠度 & 31 年間] & $6 " 1$ & $12 "$ & $24 \prime \prime$ & $48 \prime \prime$ & $72 " \prime$ & $96 "$ & $120 \prime$ & $144 \prime \prime$ & $163 "$ & $192 \prime \prime$ & $216 "$ & $240 \prime \prime$ \\
\hline \multirow{2}{*}{ 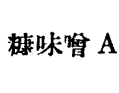 } & $13-1$ & + & + & + & + & + & - & - & - & - & - & - & - & - \\
\hline & 37 & + & + & - & - & - & - & - & - & - & - & - & - & - \\
\hline \multirow{2}{*}{ " } & $13-1$ & + & + & + & $t$ & + & + & + & + & - & - & - & - & - \\
\hline & 37 & + & + & + & + & + & - & - & - & - & - & - & - & - \\
\hline & $13-1$ & + & + & + & + & + & + & + & + & - & - & - & - & - \\
\hline & 37 & + & + & + & - & - & - & - & - & - & - & - & - & - \\
\hline
\end{tabular}

第 44 表 調製第 14 日ノ滅菌棣味頼二混和セル志賀赤痢菌

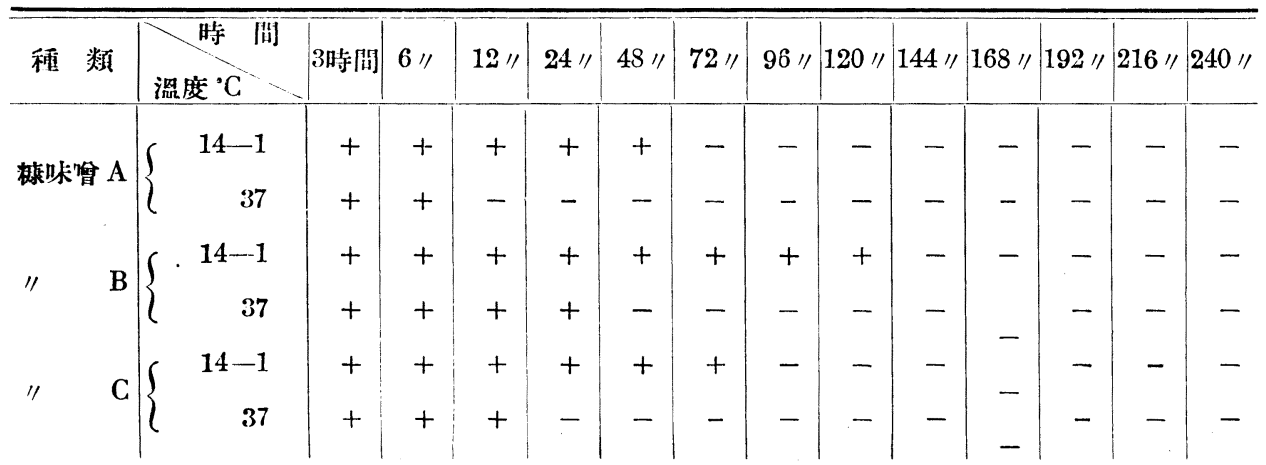


第 45 表 調製第 21 日 滅菌糠味噌二混和セル志賀赤痢菌

\begin{tabular}{|c|c|c|c|c|c|c|c|c|c|c|c|c|c|c|c|}
\hline 種 & 類 & 時 1110 & 3時問 & $6 " 1$ & $12 "$ & $24 \prime \prime$ & $48 \prime \prime$ & $72 \prime$ & $96 \prime \prime$ & $120 "$ & $144 \prime \prime$ & $163 "$ & " & $216 "$ & $240 \prime$ \\
\hline \multirow{2}{*}{ 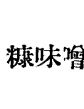 } & & $14-0$ & + & + & + & + & - & - & - & - & - & - & - & - & - \\
\hline & & 37 & + & + & - & - & - & - & - & - & - & - & - & - & - \\
\hline \multirow{2}{*}{ "I } & \multirow{2}{*}{ B } & $14-0$ & + & + & + & + & + & + & - & - & - & - & - & - & - \\
\hline & & 37 & + & + & + & - & - & - & - & - & - & - & - & - & - \\
\hline \multirow{2}{*}{ " } & $C$ & $14-0$ & + & + & + & - & - & - & - & - & - & - & - & - & - \\
\hline & & 37 & + & + & - & - & - & - & - & - & - & - & - & - & - \\
\hline
\end{tabular}

\section{6, これら菌}

これら菌ヨ調製第 3 日ノ隇菌糠味嗊二混和シ室温二放置スレバ，各糠味噌二 於テ何レモ 3 時間ニシテ死隇シ， $37^{\circ} \mathrm{C}=$ 保持スレバ，糠味噌 $\mathrm{A}=>10$ 分後们生

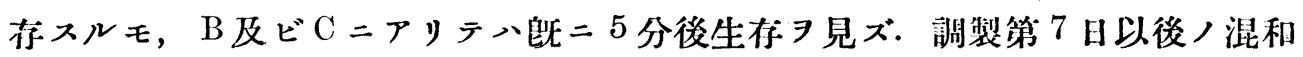
ニアリテハ何レモ既二5 分ニシテ死減ス. 其ノ成績八第 46 非乃至第 47 表二示ス ガ如シ.

第 46 表 調製第 3 日ノ隇菌糠味嗊二混和セルこれら菌

\begin{tabular}{|c|c|c|c|c|c|c|c|c|c|c|c|c|c|c|c|}
\hline 種 & 類 & $\begin{array}{l}\text { 時 間 } \\
\text { 溫度 }{ }^{\circ} \mathrm{C}\end{array}$ & 5分 & $10 " \prime$ & $15 "$ & $30 \prime \prime$ & 1時間 & $3 \prime \prime$ & $6 "$ & $12 \prime \prime$ & $24 \prime \prime$ & $48 \prime \prime$ & $72 \prime$ & \multicolumn{2}{|c|}{$96 " 120 "$} \\
\hline \multirow{2}{*}{\multicolumn{2}{|c|}{ 栤味筫 $\mathrm{A}$}} & $14-3$ & + & + & + & + & + & - & - & - & - & - & - & - & - \\
\hline & & 37 & - & + & - & - & - & - & - & - & - & - & - & - & - \\
\hline \multirow{2}{*}{ " } & \multirow{2}{*}{ B } & $14-3$ & + & + & + & + & + & - & - & - & - & - & - & - & - \\
\hline & & 37 & - & - & - & - & - & - & - & - & - & - & - & - & - \\
\hline \multirow{2}{*}{ " } & $C$ & $14-3$ & + & + & + & + & + & - & - & - & - & - & - & - & - \\
\hline & & 37 & - & - & - & - & - & - & - & - & - & - & - & - & - \\
\hline
\end{tabular}

第 47 表 調製第 7 日ノ減菌糠味骝二混和セルこれら䒩 


\begin{tabular}{|c|c|c|c|c|c|c|c|c|c|c|c|c|c|c|c|}
\hline 種 & 類 & 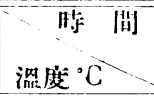 & 5 分 & $10 " \prime$ & $15 \prime \prime$ & $30 \prime$ & 1時間 & $3 \prime \prime$ & $6 " \prime$ & $12 \prime \prime$ & $24 \prime \prime$ & $48 \prime \prime$ & $72 "$ & $96 \prime \prime$ & $1.20 "$ \\
\hline \multirow{2}{*}{\multicolumn{2}{|c|}{ 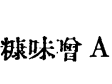 }} & $13-1$ & - & - & - & - & - & - & - & - & - & - & - & - & - \\
\hline & & 37 & - & - & - & - & - & - & - & - & - & - & - & - & - \\
\hline \multirow{2}{*}{ "I } & $\mathrm{D}$ & $13-1$ & - & - & - & - & - & - & - & - & - & - & - & - & - \\
\hline & & 37 & - & - & - & - & - & - & - & - & - & - & - & - & - \\
\hline \multirow{2}{*}{ "I } & & $13-1$ & - & - & - & - & - & - & - & - & - & - & - & - & - \\
\hline & & 37 & - & - & - & - & - & - & - & - & - & - & - & - & - \\
\hline
\end{tabular}

第 3 節 小

括

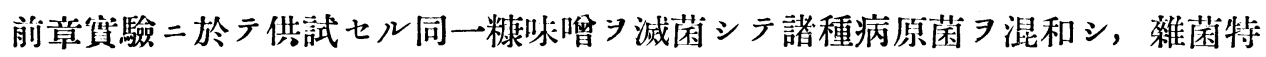

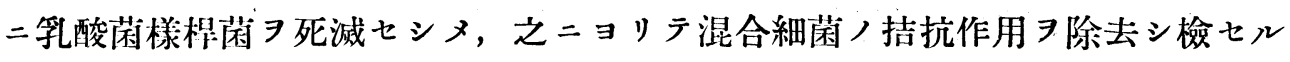

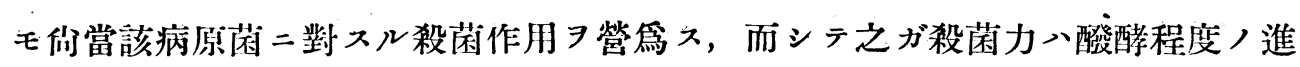

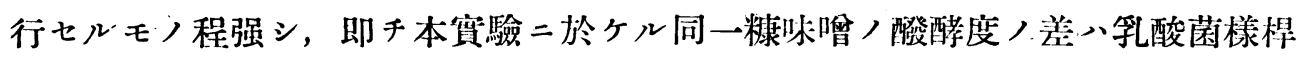
菌 $\ni$ 缺クガ故二明カ二酸度ノ高低 $ヨ$ 意味ス, 從ツテ同一糠味嗊二於テハ其ノ殺 菌力八酸度二比例ス. 又同一滅菌糠味噃二シテ酸度 之 $\exists 37^{\circ} \mathrm{C}=$ 保持スル方低盜二於ケルョリモ殺菌力强シ, 即チ豫メ隇菌シアルョ

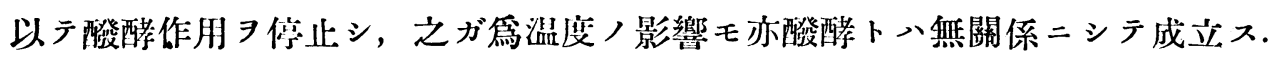
食監含有量ノ殺菌力ト關係ヨ有スルコトハ目门章二記逨セルガ如シ。茲二注意ス

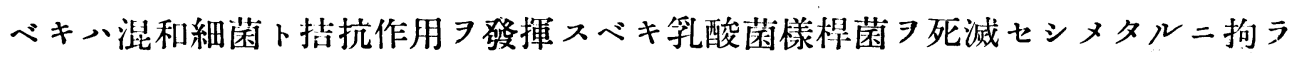

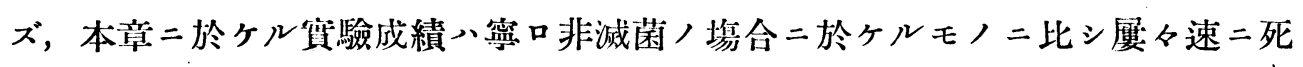
隇ヨ來ス事俥ナリ，而モ一見不合理ナルコノ現像ノ本態ハ，主トシテ隇菌操作 ニョリテ惹起七ル酸度ノ上星二因ルモノト思考スルョ以テ妥當ナリトス.

\section{第 3 章 䆂味噲乳酸菌樣桿菌卜消化器漙 染病病原苜トノ拮抗作用二就テ}

\section{第 1 節 試䛗方 法}

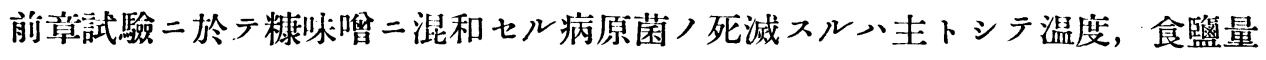
特二酸度二因ルモノナルコトヨ知レリ, 而モ乳酸菌样桿菌ノ殺菌力ヨ有スルコ トモ否ムざカラズ, 茲二本菌ト消化器傳染病病原菌ト $ヨ$ 同一培地二培稂シ夫々 


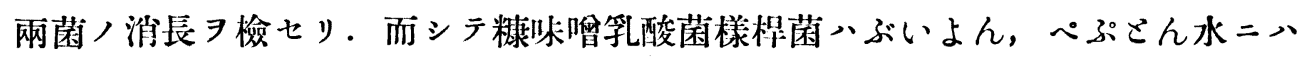
發育セザルモ葡萄糖加ぶいよんニ八良ク發育スルヨ以テ, 水素いおん漂这7.0ト 七ル $1.0 \%$ 葡萄糖加ぶいよん $3.0 \mathrm{cc}$ 中二乳酸菌樣椙菌及ビ各種消化器傳染病病原

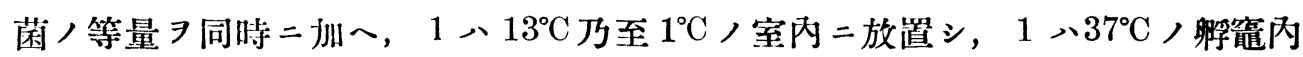
二保于, 時間的二各菌ノ生死 $\exists$ 檢セり, 即于乳酸菌樣㮛菌 $1.0 \%$ 葡萄糖加寒

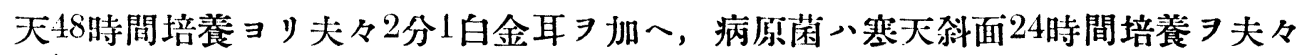

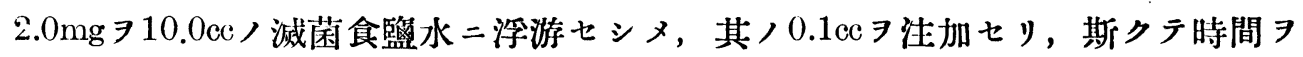
劃シテー白金耳 7 釣取, $1.0 \%$ 葡萄糖加寒天二叙抹培竟セリ.

\section{第 2 篩 豈 驗成績}

1, 普通大腸菌

普通大腸菌卜乳酸菌樣桿菌ト 71 個, $1.0 \%$ 葡萄糖加ぶいよん培地二培養シ 之ヨ室温二保ットキハ, 普通大腸菌、 144 時間, $37^{\circ} \mathrm{C}=$ 保ットキハ既二 24 時間, ニシテ死隇シ, 乳酸菌樣桿菌、置口增殖ス. 其ノ成績、第 48 表ノ如シ.

\section{第 48 表 乳酸菌樣桿菌卜普通大晹菌}

\begin{tabular}{|c|c|c|c|c|c|c|c|c|c|c|c|c|c|c|c|c|c|}
\hline 罝度 & $\begin{array}{l}\text { 時 間 } \\
\text { 種 類 }\end{array}$ & 5分 & $10 \prime$ & $15 \prime \prime$ & $30 \prime$ & 1時間 & $3 \prime$ & $6 \prime \prime$ & $12 \prime \prime$ & $84 \prime \prime$ & $48 \prime \prime$ & $72 \prime$ & $96 "$ & $120 "$ & $144 \prime \prime$ & \multicolumn{2}{|c|}{$168 " 192 "$} \\
\hline $13^{\circ} \mathrm{C}$ & 㬐通大腸菌 & $H$ & H & $H$ & H & H & $H$ & $H$ & $H$ & $H$ & tt & + & + & + & - & - & - \\
\hline $1^{\circ} \mathrm{C}$ & 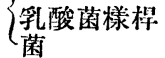 & $H$ & $H$ & H & H & $H$ & $H$ & $H$ & H & $H$ & H & H & H & H & H & H & H \\
\hline & (普通大腸菌 & $H$ & $H$ & $H$ & $H$ & $H$ & + & + & + & - & - & - & - & - & - & - & - \\
\hline & $\left\{\begin{array}{l}\text { 孚酸菌樣桿 } \\
\text { 萡 }\end{array}\right.$ & H & $H$ & H & H & H & $H$ & H & H & H & H & H & H & H & H & H & H \\
\hline
\end{tabular}

\section{2 , ちふす菌}

ちふす菌、乳酸菌漛暒菌, 發奆旺盛ナル二反シ室温二テハ168時間後渐ク死 隇スルモ, $37^{\circ} \mathrm{C}=$ テハ24時間二シテ死隇ス. 其ノ成績ハ第 49 装二示スガ如シ.

\section{第 49 表 乳酸菌樣棹菌トちふす菌}

\begin{tabular}{|c|c|c|c|c|c|c|c|c|c|c|c|c|c|c|c|c|c|}
\hline 洫度 & \begin{tabular}{|c|c|} 
& 種 数 \\
時 & 間
\end{tabular} & 5分 & $10 \prime$ & $15^{\prime \prime}$ & $30 \prime$ & 1 洔間 & $3 \prime \prime$ & $6 \prime \prime$ & $12 \prime$ & 24 " & 48 & $72 "$ & 96 & 120 & $144 \prime \prime$ & 163 & $192 \prime$ \\
\hline $\begin{array}{l}13^{\circ} \mathrm{C} \\
\text { 乃至 } \\
1^{\circ} \mathrm{C}\end{array}$ & $\left\{\begin{array}{l}\text { ち ふ、寸菌 } \\
\text { 乳酸菌栐桿 } \\
\text { 菌 }\end{array}\right.$ & $\begin{array}{l}H \\
H\end{array}$ & $\begin{array}{l}\text { Ht } \\
\text { H }\end{array}$ & $\begin{array}{l}H \\
H\end{array}$ & $\begin{array}{l}H \\
H\end{array}$ & $\begin{array}{l}H \\
H\end{array}$ & $\begin{array}{l}H \\
H\end{array}$ & $\begin{array}{l}H \\
H\end{array}$ & $\begin{array}{l}H \\
H\end{array}$ & $\begin{array}{l}+ \\
H\end{array}$ & $\begin{array}{l}+ \\
+\end{array}$ & $\begin{array}{l}+ \\
H\end{array}$ & $\begin{array}{l}+ \\
H\end{array}$ & $\begin{array}{c}+ \\
H\end{array}$ & $\begin{array}{l}+ \\
H\end{array}$ & $\begin{array}{l}- \\
H\end{array}$ & $\begin{array}{l}- \\
H\end{array}$ \\
\hline
\end{tabular}




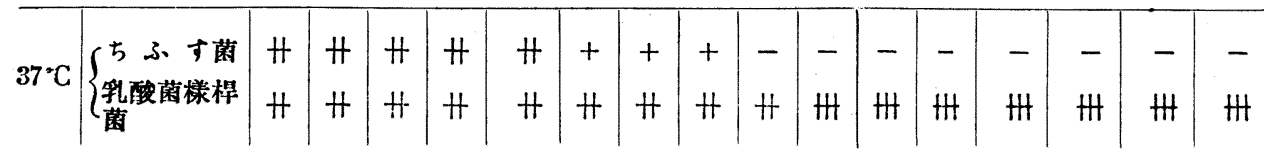

\section{3、ぱらちふすA菌}

ぱらちふす $\mathrm{A}$ 菌ニ於テモ室温ニテハ144時間， $37^{\circ} \mathrm{C}=テ ハ 24$ 時間ニシテ菌ノ 發育ヨ見ズ，其ノ成績ハ第50表二示スガ如シ.

第 50 表 乳酸菌樣桿菌トぱらちふすA菌

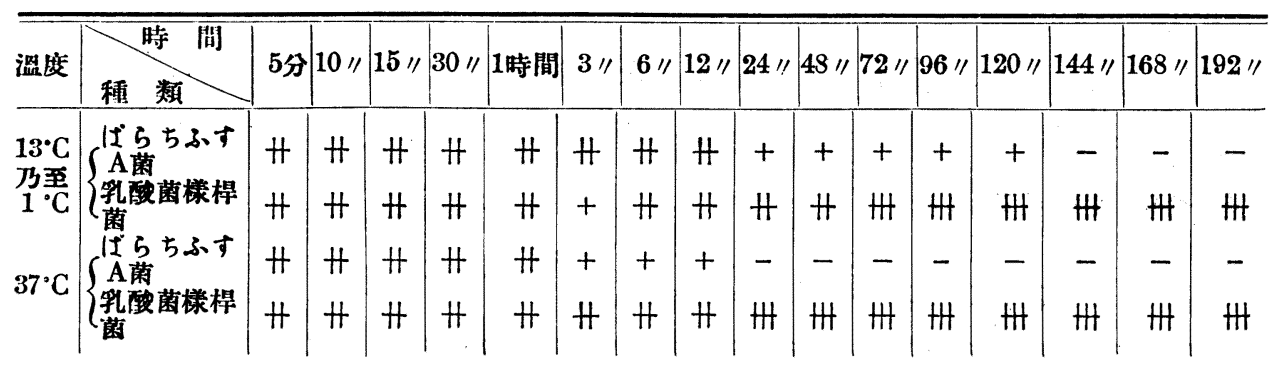

\section{4, ぱらちふす B菌}

乳酸菌樣桿菌トぱらちふす $\mathrm{B}$ 菌トノ拮抗作用二就テ見ル二前者ノ發育旺盛ナ ルニ反シ,ぱらちふす $\mathrm{B}$ 菌い室蕰ニテハ 192 時間, $37^{\circ} \mathrm{C}=$ テ 24 時間ニシテ死 隇大. 其ノ成績》第51表二示スガ如シ.

第 51 表 乳酸菌樣桿菌トぱらちふす $\mathrm{B}$ 菌

\begin{tabular}{|c|c|c|c|c|c|c|c|c|c|c|c|c|c|c|c|c|c|}
\hline 㬈度 & 種 数 & 5分 & $10 \prime$ & $15 \prime \prime$ & $30 \prime$ & 1時間 & $3 \prime \prime$ & $6 \prime$ & $12 \prime \prime$ & $24 \prime \prime$ & $48 \prime \prime$ & $72 "$ & 92 । & $120 \prime$ & 144 & $168 \prime$ & 192 " \\
\hline $3^{\circ} \mathrm{C}$ & 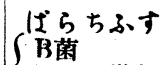 & H & $H$ & $H$ & $H$ & H & H & $H$ & $H$ & $H$ & + & + & + & + & + & + & - \\
\hline 融 & 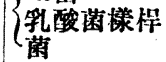 & $H$ & $H$ & \# & H & H & $H$ & $H$ & H & $H$ & $H$ & \# & H & H & H & $\mathrm{H}$ & H \\
\hline $7^{\circ} \mathrm{C}$ & 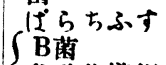 & H & H & $H$ & H & $H$ & H & + & + & - & - & - & - & - & - & - & - \\
\hline & 熖酸菌様桿 & H & $H$ & $H$ & $H$ & $H$ & $H$ & $H$ & $H$ & $H$ & \# & H & H & H & $H$ & H & HH \\
\hline
\end{tabular}

5 , 志賀型赤痢菌

室盜二テハ 168 時間, $37^{\circ} \mathrm{C}=$ テ 48 時間ニシテ死隇シ, 之二反シ乳酸菌樣桿

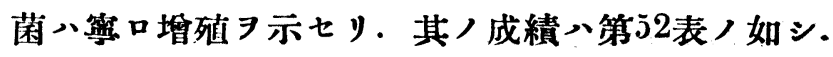


第 52 表 乳酸菌樣棹菌卜志賀赤痢菌

\begin{tabular}{|c|c|c|c|c|c|c|c|c|c|c|c|c|c|c|c|c|c|}
\hline 溫度 & $\begin{array}{l}\text { 時 间 } \\
\text { 種 類 }\end{array}$ & 5分 & $10 \prime$ & $15 \prime$ & $30 \prime$ & 1時閑 & $3 \prime$ & $6 " \prime$ & 12 & 24 & 48, & $72 \prime$ & $93 "$ & 1.20 & $144 \prime \prime$ & 168 & $192 "$ \\
\hline $13^{\circ} \mathrm{C}$ & 志賀赤㾥菌 & $H$ & $H$ & H & H & H & H & H & H & + & + & + & + & + & + & - & - \\
\hline $1^{\circ} \mathrm{C}$ & 琈酸菌樣怾 & $H$ & $H$ & H & H & H & H & $H$ & $H$ & H & H & H & H & W & W & H & H \\
\hline & C志賀赤痢莉 & H & H & H & H & H & H & + & + & + & - & - & - & - & - & - & - \\
\hline 4 & 孚酸菌栐椙 & $H$ & $H$ & H & H & H & H & H & H & Ht & H & H & H & H & H. & H & H \\
\hline
\end{tabular}

6, これ.ら菌

これら菌ト乳酸菌樣桿菌トノ拮抗試驗二於テハ, これら菌い之ヨ室温二保ッ トキハ 12 時間，之 $337^{\circ} \mathrm{C}=$ 保ツトキハ既二 3 時間ニシテ菌ノ發育 成績ハ第53表ノ如シ.

第 53 表 乳酸菌樣桿菌トこれら菌

\begin{tabular}{|c|c|c|c|c|c|c|c|c|c|c|c|c|c|c|c|c|c|}
\hline 溫度 & 種 数 & 5分 & $10 " 1$ & 15 & " & 1時間 & $3 \prime \prime$ & $6 " 1$ & $12 "$ & $24 \prime$ & $48 \prime$ & $72 "$ & $96 "$ & $120 "$ & $144 "$ & $163 "$ & 192 \\
\hline $7^{\circ} \mathrm{C}$ & $r=れ ら$ 菌 & H & H & $H$ & H & + & + & + & - & - & - & - & - & - & - & - & - \\
\hline $\begin{array}{l}3 \text { 至 } \\
1^{\circ} \mathrm{C}\end{array}$ & $\begin{array}{l}\text { 乳酸菌樣棉 } \\
\text { 菂 }\end{array}$ & H & H & H & $H$ & H & $H$ & $H$ & H & H & H & H & H & H & H & H & H \\
\hline $7^{\circ} \mathrm{C}$ & $r=れ ら$ 莉 & HH & H & + & + & + & - & - & - & - & - & - & - & - & - & - & - \\
\hline 14 & 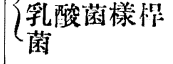 & $H$ & H & $H$ & $H$ & H & H & $H$ & $H$ & $H$ & H & H & H & H & H & H & H \\
\hline
\end{tabular}

\section{第 3 簕 小}

\section{括}

前章ノ實驗二於テ乳酸菌樣暒菌卜各種消化器傳染病病原莉卜ノ拮抗作用ノ有

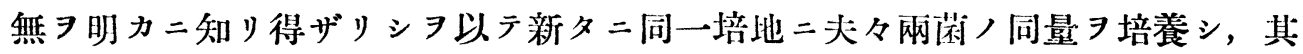
八間二於ヶル菌ノ運命 7 觀察七ル二, 是等兩者間二八朋カ二强キ拈抗作用 7 有 シ $37^{\circ} \mathrm{C}$ 二保持スルトキ病原菌ノ多クハ24月尔間ニシテ死減シ, 特二これら菌ノ如 キハ早クモ 3 時間ニシテ死減シ去ハニ反シ, 乳酸菌樣桿菌ハ48時間前後ヨリ密 口增殖 秝スコトヨ知レリ。

\section{第 4 章 各種濃度ノ乳酸溶液中ニ於ケル消}

\section{化器傅染病病原菌ノ運命二就テ}




伊庭吉集速

(1517)

\section{第 1第成方法}

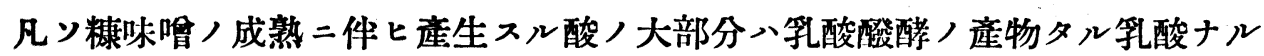
コトメ井上, 渡邊及ビ岡村ノ試驗ニョリテ明カナリ. 是二於テ余ハ各種濃度 異二セル乳酸水溶液 7 製出シ, 消化器傳染病病原菌 $\ni$ 混和シテ夫々混和細菌, 運命二就テ試驗セリ。

即チしえーつんぐ・か一ろばうむ製乳酸（比重1.21） ヨリ滅菌蒸餾水 1.もる溶液 $(1.0 \mathrm{cc}$ 苛性加里定規液 $1.0 \mathrm{cc}=ヨ リ テ$ 完全二中和セラル)二製シ，之 $\exists$ 以テ原液トナシ，夫々 10 分 $1 ， 20$ 分 $1 ， 50$ 分 1 及ビ 100 分 1 水溶液トシテ稀釋製 出ス, 而シテ是等各種ノ乳酸水溶液 $1.0 \mathrm{cc}$ 中二, 24 時間培養ノ与記 6 種 / 病原菌 夫々 2 分 1 白金耳 7 混ジ，攝氏 $14^{\circ} \mathrm{C}$ 乃至 $4^{\circ} \mathrm{C}$ ノ室內及ビ $37^{\circ} \mathrm{C}$ ノ捊䆓二保チ，時間 ヨ劃シテ各々其ノ 1 白金耳量 無ニョリテ混和菌ノ生死 $コ$ 制定セリ.

\section{第 2 第 豈酸成}

1, 普通大腸菌

1 る 笔酸水溶液二普通大腸菌 $コ$ 混和スレバ室温二於テモ亦 $37^{\circ} \mathrm{C}=$ 於テモ䠶 二 5 分ニシテ死隇シ, 10 分 1 液ニテハ室温ニテハ 15 分, $37^{\circ} \mathrm{C}=$ テ 5 分ニシテ死 隇入, 20 分 1 液二テハ室盜 $=30$ 分, $37^{\circ} \mathrm{C}=15$ 分 ニシテ死隇ス, 又50分 1 液二於テ

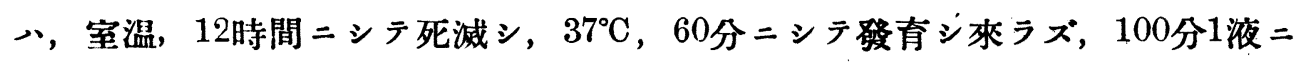
テハ室温二保ットキ24時間後二於テ份生存 $\exists$ 續クルモ, $37^{\circ} \mathrm{C}=$ 保ットキハ 3 時 間ニシテ死隇スルョ見タリ，其ノ成績ハ第54表ノ如シ.

第 54 表 各種乳酸溶液中二於ヶル普通大腸菌

\begin{tabular}{|c|c|c|c|c|c|c|c|c|c|c|c|c|c|c|c|c|}
\hline 種 類 & 時 間 & 5分 & $10 \prime$ & $15 \prime \mid$ & $30 \prime$ & 1時間 & $3 \prime \prime$ & $6 " 1$ & $12 \prime$ & $24 \prime \prime$ & 48 " & $72 "$ & $96 \prime \prime$ & $120 "$ & $144 "$ & 168 !" \\
\hline 1， 万汸 & $14-4$ & - & - & - & - & - & - & - & - & - & - & - & - & - & - & - \\
\hline 100 on & 37 & - & - & - & - & - & - & - & - & - & - & - & - & - & - & - \\
\hline 10 弪 14 & $14-4$ & + & + & - & - & - & - & - & - & - & - & - & - & - & - & - \\
\hline 万液 & 37 & - & - & - & - & - & - & - & - & - & - & - & - & - & - & - \\
\hline
\end{tabular}




\begin{tabular}{|c|c|c|c|c|c|c|c|c|c|c|c|c|c|c|c|c|}
\hline 種 類 & 昦度 ${ }^{\circ} \mathrm{C}$ & 5 分 & $10 \prime \prime$ & $15 \prime \prime$ & $30 \prime$ & 1時閑 & $3 \prime \prime$ & $6 " \prime$ & $12 \prime$ & $24 \prime \prime$ & 48 & $72 \prime$ & $96 \%$ & $120 "$ & 114 & $163 "$ \\
\hline 20分 1 娄 & $\{14-4$ & + & + & + & - & - & - & - & - & - & - & - & - & - & - & - \\
\hline 己液 & 37 & + & + & - & - & - & - & - & - & - & - & - & - & - & - & - \\
\hline 50 分 1 女 & $\{14-3$ & + & + & + & + & + & + & + & - & - & - & - & - & - & - & - \\
\hline 万液 & 37 & + & + & + & + & - & - & - & - & - & - & - & - & - & - & - \\
\hline 100 分 1 t & $14-4$ & + & + & + & + & + & + & + & + & + & - & - & - & - & - & - \\
\hline る液 & 37 & + & + & + & + & + & - & - & - & - & - & - & - & - & - & - \\
\hline
\end{tabular}

\section{2, ちふす菌}

本菌モ亦 1 る筓酸溶液中二於テハ5分ニシテ既二發育シ來ラズ, 10 分 1 液 ニテ 、室温二於テ10分間生存シ, $37^{\circ} \mathrm{C}=$ 於テハ5.分ニシテ死隇下, 20 分 1 液二 テ八室温二テ 30 分, $37^{\circ} \mathrm{C}=$ 二 10 分ニシテ死滅ス, 50 分 1 液二テハ室温二テ 60 分, $37^{\circ} \mathrm{C}=$ テ 15 分間生存入, 100 分 1 液二於テハ室温二テ 12 㭙間, $37^{\circ} \mathrm{C}=$ テ 3 時間後 ニ八菌ノ發育 7 見ズ, 其ノ成績ハ第55表二示スガ如シ.

第 55 表 各種乳酸溶液中二於ヶルちふす菌

\begin{tabular}{|c|c|c|c|c|c|c|c|c|c|c|c|c|c|c|c|c|}
\hline 種 類 & 時 間 & 5分 & $10 "$ & $15 \prime \prime$ & $30 " \prime$ & 1時問 & $3 \prime$ & $6 "$ & 12 & $24 \prime \prime$ & $48 \prime \prime$ & 72 & $96 \prime$ & $120 "$ & 144 & $163 "$ \\
\hline 11 万液 & $14-4$ & - & - & - & - & - & - & - & - & - & - & - & - & - & - & - \\
\hline 年 & 37 & - & - & - & - & - & - & - & - & - & - & - & - & - & - & - \\
\hline & $14-4$ & + & + & - & - & - & - & - & - & - & - & - & - & - & - & - \\
\hline$t$ & 37 & - & - & - & - & - & - & - & - & - & - & - & - & - & - & - \\
\hline 20分 1 も & $14-4$ & + & + & + & - & - & - & - & - & - & - & - & - & - & - & - \\
\hline & 37 & + & - & - & - & - & - & - & - & - & - & - & - & - & - & - \\
\hline 50分 1 も & $14-4$ & + & + & + & + & + & - & - & - & - & - & - & - & - & - & - \\
\hline & 37 & + & + & + & - & - & - & - & - & - & - & - & - & - & - & - \\
\hline & $14-4$ & + & + & + & + & + & + & + & - & - & - & - & - & - & - & - \\
\hline & 37 & + & + & + & + & + & - & - & - & - & - & - & - & - & - & - \\
\hline
\end{tabular}

3 ぱらちふすA菌

ぱらちふすA菌い1もる液及ビ10分 1 液何レニ於テモ既二混和後 5 分ニシテ 死隇ス，20分 1 液ニテハ室淂二保ットキノミ5分二亘リテ生存ス，又50分 1 液 
ニテハ室盜二テ60分二亘リ生存 7 續ケ, $37^{\circ} \mathrm{C}=$ テ 30 分ニシテ死隇ス, 100 分 1 液ニテハ室温二保ツトキ6 時間後劣生存シ, $37^{\circ} \mathrm{C}=$ 保ツトキ60分後二八發育シ 來ラズ，其ノ成績ハ第 56 表二示スガ如シ.

第 56 表 各種乳酸溶液中二於ヶルばらちふすA菌

\begin{tabular}{|c|c|c|c|c|c|c|c|c|c|c|c|c|c|c|c|c|}
\hline 種 類 & 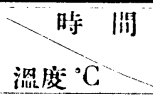 & 5分 & $10 \prime$ & $15 \prime \prime$ & $30 "$ & 1 時閑 & $3 \prime$ & 611 & $12 \prime \prime$ & $24 \prime \prime$ & " & $72 " \prime$ & $96 \prime$ & $12{ }^{\prime \prime}$ & |" & 168 " \\
\hline & $14-4$ & - & - & - & - & - & - & - & - & - & - & - & - & - & - & - \\
\hline 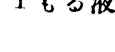 & 37 & - & - & - & - & - & - & - & - & - & - & - & - & - & - & - \\
\hline & $14-4$ & - & - & - & - & - & - & - & - & - & - & - & - & - & - & - \\
\hline $\begin{array}{l}10 \text { 分 } \\
\text { 万液 }\end{array}$ & 87 & - & - & - & - & - & - & - & - & - & - & - & - & - & - & - \\
\hline & $14-4$ & + & - & - & - & - & - & - & - & - & - & - & - & - & - & - \\
\hline 万液 & 37 & - & - & - & - & - & - & - & - & - & - & - & - & - & - & - \\
\hline & $14-4$ & + & + & + & + & + & - & - & - & - & - & - & - & - & - & - \\
\hline 万液 & 37 & + & + & + & - & - & - & - & - & - & - & - & - & - & - & - \\
\hline & $14-4$ & + & + & + & + & + & + & + & - & - & - & -- & - & - & - & - \\
\hline & 37 & + & + & + & + & - & - & - & - & - & - & - & - & - & - & - \\
\hline
\end{tabular}

4, ぱらちふす B菌

本菌、 1 る液及ビ 10 分 1 液中二八發育セズ, 20 分 1 液二テ室温二保ットキ 30 分後们生存スルモ, $37^{\circ} \mathrm{C}=$ テ 10 分ニシテ死隇ス, 又50分 1 液二テハ室温二 テ 6 時間, $37^{\circ} \mathrm{C}=$ テ30分間後二、發育シ來ラズ, 100 分 1 液ニテハ室温二テ 12 時 間, $37^{\circ} \mathrm{C}=$ テ 3 時間二亘り生存ス，其ノ成績、第57表二示スガ如シ.

第 57 表 各種乳酸溶液中二於ヶルぱらちふす $\mathrm{B}$ 菌

\begin{tabular}{|c|c|c|c|c|c|c|c|c|c|c|c|c|c|c|c|c|}
\hline 種 類 & 㴓度 ${ }^{\circ} \mathrm{C}$ & 5分 & 10分 & $15 \prime \prime$ & $30 \prime$ & 1時間 & $3 \prime \prime$ & $6 \prime \prime$ & $12 "$ & $24 \prime$ & $48 \prime \prime$ & $72 \prime$ & $96 \prime$ & $120 "$ & $144 \prime \prime$ & 168 \\
\hline & $14-4$ & - & - & - & - & - & - & - & - & - & - & - & - & - & - & - \\
\hline & 37 & - & - & - & - & - & - & - & - & - & - & - & - & - & - & - \\
\hline & $14-4$ & - & - & - & - & - & - & - & - & - & - & - & . & - & - & - \\
\hline & 37 & - & - & - & - & - & - & - & - & - & - & - & - & - & - & - \\
\hline 20 & $14-4$ & + & + & + & + & - & - & - & - & - & - & - & - & - & - & - \\
\hline 万液 & 37 & +1 & -1 & $1-1$ & $1-$ & - & -1 & -1 & -1 & $1-1$ & - & $1-1$ & -1 & - & - & - \\
\hline
\end{tabular}




\begin{tabular}{l}
\hline \hline 種 類 \\
\hline 潈度 ${ }^{\circ} \mathrm{C}$
\end{tabular}

\section{5 , 志賀型赤痢菌}

本菌 1 もる液, 10 分 1 液及ビ 20 分 1 液二混 $シ 37{ }^{\circ} \mathrm{C}=$ 保ツトキハ速二死隇シ 室温二放寔スルトキハ10分 1 液二テハ10分, 20 分 1 液ニテハ60分ニシテ死減 ス. 50 分 1 液二於テハ之 7 室温二保ットキ 3 時間, $37^{\circ} \mathrm{C}=$ 保ットキ15分後侕生 存万. 又 100 分 1 液二テハ宾温二於テ 6 時間, $37^{\circ} \mathrm{C}$ 二於テ 60 分後们生存ス. 其 ノ成績ハ第58表二示スガ如シ.

\section{第 58 表 各種乳酸溶液中二於ヶル志賀赤痢菌}

\begin{tabular}{|c|c|c|c|c|c|c|c|c|c|c|c|c|c|c|c|c|}
\hline 程 類 & 㴓度 ${ }^{\circ} \mathrm{C}$ & 5分 & $10 \prime \mid$ & $15 \prime$ & $30 \prime$ & 10时们 & $3 "$ & $6 " 1$ & $12 \prime$ & $24 \prime \prime$ & $48 \prime \prime$ & $72 \prime \prime$ & $96 "$ & $120 "$ & $144 \prime \prime$ & $168 "$ \\
\hline & $14-4$ & - & - & - & - & - & - & - & - & -- & - & - & - & - & - & - \\
\hline 1 t & 37 & - & - & - & - & - & - & - & - & - & - & - & - & - & - & - \\
\hline & $14-4$ & + & - & - & - & - & - & - & - & - & - & - & - & - & - & - \\
\hline 石液 & 37 & - & - & - & - & - & - & - & - & - & - & - & - & - & - & - \\
\hline & $14-4$ & + & + & + & + & - & - & - & - & - & - & - & - & - & - & - \\
\hline 了液 & 37 & - & - & - & - & - & - & - & - & - & - & - & - & - & - & - \\
\hline 50 公 1 & $14-4$ & + & + & + & + & + & + & - & - & - & - & - & - & - & - & - \\
\hline 万液 & 37 & + & + & + & - & - & - & - & - & -- & - & - & - & - & - & - \\
\hline & $14-4$ & + & + & + & + & + & + & + & - & - & - & - & - & - & - & - \\
\hline 万液 & 37 & + & + & + & + & + & - & - & - & - & - & - & - & - & - & - \\
\hline
\end{tabular}

\section{6, こ和ら菌}

これら菌一乳酸溶液, 酸度二對シテモ之ヨ爾餘病原菌二比シテ抵抗甚シク薄 弱ナリ。即チ100分 1 液二於テ既二5分後二八死隇スルア貫驗セリ。 


作庭吉雄述

\section{第 3 節 小}

括

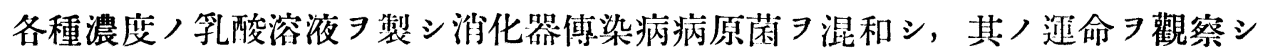
タルニ一定時間ト一定温度トノ下二何レノ菌モ必ズ死隇シ, 特ニこれら菌二至 リテハ乳酸二對スル抵抗極メテ薄弱ナリ．即チこれら菌、100 分 1 るる乳酸溶 液中二於テ 5 分間ノ生存 $モ$ 許ルサズ. 又比較的抵抗强キぱらちふすB菌卜雖 $37^{\circ} \mathrm{C} / 100$ 分 1 る 液中二テリテハ 6 時間後完全死減 7 來ス。一般二是等各菌

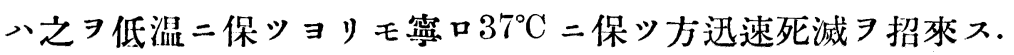

\section{第 5 章 各種濃度ノ食監溶液中二於ケル消化器傳 染病病原菌ノ運命二就テ \\ 第 1 節 試 驗方 法}

䆂味骝ノ總酸度二大恙ナク，且食監含有量 $\ni$ 異ニスル2種ノ材料二同一菌株 ヨ同一條件ノ下二混和スルトキ, 食監含有量大ナル力他ノモノ二比シ速二死隇

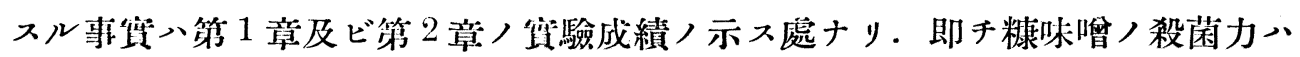
食監含有量ニョリテ亦影響セラル。仍テ余ハ各種濃度ノ食鹽水溶液ヨ製シ, 前 記消化器傳染病病原藏 9 混ジ其ノ迎命 知ラントセリ。

先ジ $15^{\circ} \mathrm{C}$ 二於テ日本藥局方, 食監ヨ以テ佨和水溶液（も-る氏法二依り滴定 シタルニ本液 $1.0 \mathrm{cc}$ 中 $=036 \mathrm{~g}$ 人食監 9 含有ス, 即チ $36.0 \%$ 二該當ス) 二製シ, 之ヨ以テ原液トナシ, 夫々 2 分 1 液, 5 分 1 液二稀釋シ, 各稀釋液 $1.0 \mathrm{cc}$ 中 $=24$ 時間培養，上記諸病原莉 2 分 1 白金耳量 7 加 , $15^{\circ} \mathrm{C}$ 乃至 $3^{\circ} \mathrm{C}$ ，室內站 $=37^{\circ} \mathrm{C}$

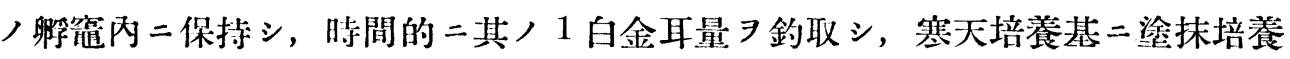
シ, 集落發生ノ有無ニョリテ㐿ノ生死

\section{第 2 節 寊 驗 成 綪}

1, 普通大腸菻

本菌、室温二放㯰セル饱和食監水中ニアリテハ 48 時間, $37^{\circ} \mathrm{C}=\bar{テ} 12$ 時間二 シテ死隇シ， 2 分 1 稀釋饱和食監水中ニアリテハ室温二テ 168 時間, $37^{\circ} \mathrm{C}=テ$ 24 時間後集落 9 發生シ來ラズ, 5 分 1 稀釋液二於テハ之ヨ室温二保ットキ216 
時間後佾克ク生存スレドモモ， $37^{\circ} \mathrm{C}=$ 保ツトキハ 120 時間ニシテ死隇スベシ. 其 ノ成績 第59表二示スガ如シ.

第 59 表 各種食監溶液中二於ヶル普通大腸菌

\begin{tabular}{l}
\hline 種類 \\
\hline 溫度 ${ }^{\circ} \mathrm{C}$
\end{tabular}

2 万 ちすす菌

本菌、食監饱和液中二於テ $>37^{\circ} \mathrm{C}=$ 於テ 12 時間, 室温二於テ 48 時間ニシテ死 滅シ, 2 分 1 饱和食監水中二於テ $>37^{\circ} \mathrm{C}=$ 於テ 24 時間, 室温二於テ 168 時間二 シテ死隇入. 又 5 分 1 饱和食鹽水中二於テハ, $37^{\circ} \mathrm{C}$ 二保ットキ96時間ニシテ初 ヌテ本菌ノ死隇 7 來ス. 其ノ成績、第 60 表二示スガ如シ.

第 60 表 各種食監溶液中二於ヶルちふす菌

\begin{tabular}{|c|c|c|c|c|c|c|c|c|c|c|c|c|c|c|c|c|c|}
\hline 種数 & 溫㢑 ${ }^{\circ} \mathrm{C}$ & 5分 & $10 \prime \prime$ & $15 \prime$ & $30 \prime \prime$ & 1時間 & $3 \prime \prime$ & $6 \prime \prime$ & $12 \prime \prime$ & $24 \prime \prime$ & $48 \prime \prime$ & $72 \prime \prime$ & $95 \prime \prime$ & $120 "$ & 144 " & $163 "$ & $192 \prime \prime$ \\
\hline & $\int 15-3$ & + & + & + & + & + & + & + & + & + & - & - & - & - & - & - & - \\
\hline & l 37 & + & + & + & + & + & + & + & - & - & - & - & - & - & - & - & - \\
\hline 2 分 1 飾 & $\{15--3$ & + & + & + & + & + & + & + & + & + & + & + & + & + & + & - & - \\
\hline 利液 & 37 & + & + & + & + & + & + & + & + & - & - & - & - & - & - & - & - \\
\hline 5分 1 & $\{15-3$ & + & + & + & + & + & + & + & + & + & + & + & + & + & + & + & + \\
\hline 和液 & 37 & + & + & + & + & + & + & + & + & + & + & + & - & - & - & - & - \\
\hline
\end{tabular}

3、ぱらちふすA菌

本菌 $37^{\circ} \mathrm{C}=$ 保持セル飽和食監水中二於テハ 12 時間, 室温二保持セルトキハ

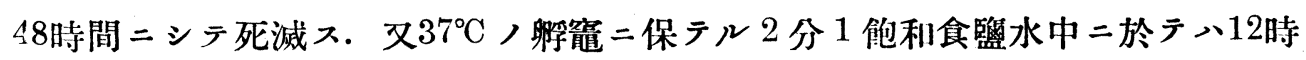




$$
\text { 作庭吉雄逝 }
$$

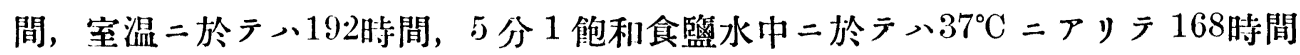
ニシテ死滅ス. 其ノ成績八第 61 表ノ如シ.

第 61 表＼cjkstart各種食監溶液中二於ヶルばらちふす $\mathrm{A}$ 菌

\begin{tabular}{l}
\hline \hline 程類 \\
\hline 溫度 ${ }^{\circ} \mathrm{C}$
\end{tabular}

\section{4, ぱらちふず B菌}

本菌一佨和食監水中二於テ $37^{\circ} \mathrm{C}=$ 保 $ト キ 24$ 時間, 室温二保ツトキ72時間二 シテ死滅シ， 2 分 1 液ニアリテ $37^{\circ} \mathrm{C}=48$ 時間，室温二テハ 168 時間ニシテ死隇

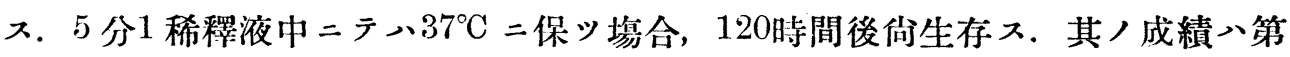
62 表二示スガ如シ.

第 62 表 各種食監溶液中二於ケルぱらちふす $\mathrm{B}$ 菌

\begin{tabular}{|c|c|c|c|c|c|c|c|c|c|c|c|c|c|c|c|c|c|}
\hline 種類 & 脿度 ${ }^{\circ} \mathrm{C}$ & 5分 & $10 "$ & ו ו" & $30 "$ & 1時間 & $3 "$ & $6 " 1$ & $12 "$ & $24 \prime \prime$ & 48 & $72 \prime \prime$ & $96 " 1$ & $120 "$ & 144 & $163 "$ & $192 "$ \\
\hline & $15-3$ & + & + & + & + & + & + & + & + & + & + & - & - & - & - & - & - \\
\hline Fent? & 37 & + & + & + & + & + & + & + & + & - & - & - & - & - & - & - & - \\
\hline & $\int 15-3$ & + & + & + & + & + & + & + & + & + & + & + & + & + & + & - & - \\
\hline 和液 & 37 & + & + & + & + & + & + & + & + & + & - & - & - & - & - & - & - \\
\hline & $\int^{15-3}$ & + & + & + & + & + & + & + & + & + & + & + & + & + & + & + & + \\
\hline 和液 & 37 & + & + & + & + & + & + & + & + & + & + & + & + & + & - & - & - \\
\hline
\end{tabular}

\section{5 ，志賀型赤疮䒩}

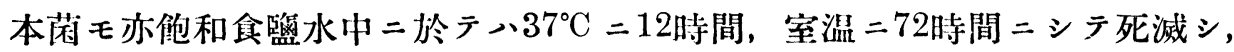
2 分 1 稀釋液二テ $37^{\circ} \mathrm{C}$ 二於テ 12 時間, 室温二於テハ 120 時間, 5 分 1 液ニテふ 
(1524)

$37^{\circ} \mathrm{C}=48$ 時間 $=$ シテ死滅ス. 其ノ成績ハ第 63 表ニ示スガ如シ.

第 63 表 各種食監溶液中二於ヶル志賀赤痢获

\begin{tabular}{l}
\hline 種類 \\
\hline 溫度 ${ }^{\circ} \mathrm{C}$
\end{tabular}

6, こ狄ら菌

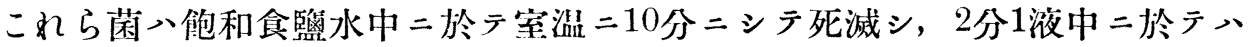
之 $737^{\circ} \mathrm{C}=$ 保ットキ5分間生存シ，室温二保持スレバ1時間生存ス心シシ，又5分 1 液中二於テハ室温ト孵䆨温トヨ問、ズ1時間後、生存スレドモ3時間後二、死減 スルョ見タリ。其ノ成績八第 64 表二示スガ如シ.

第 64 裴 各種食盬溶液中二於ヶルこれら藏

\begin{tabular}{l}
\hline 種颣 \\
\hline 潈度 ${ }^{\circ} \mathrm{C}$
\end{tabular}

余ハ本章ノ實驗二於テ $36.0 \% ， 18.0 \%$ 及ビ $7.2 \%$ /食監水中二消化器傳染病病 原菌 テ叙上各種病原菌ノ內こるら菌ノ抵抗最モ弱ク $7.2 \%$ 溶液中二於テハ 3 時間後死 


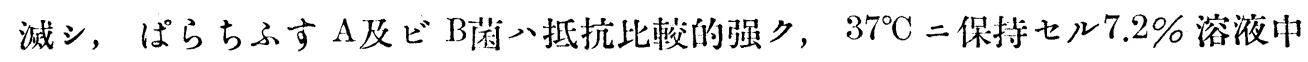
二於テハ144時間乃至 120 時間二亘りテ生存ス, 而シテ是等食辟溶液ノ殺菌性》 又温度ニョリテ影響七ラルルコト明白ナリ, 即チ室温二於テスルョリモ $37^{\circ} \mathrm{C}$,

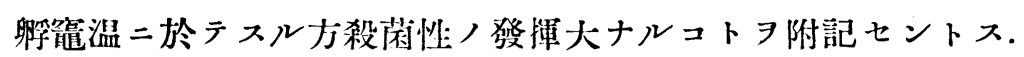

\section{總括}

余・食監含有量 日，第 7 日，第 14 日及ビ第 21 日ノ各時期二於ケル糠味㗱二普樋大晹菌，ちふす

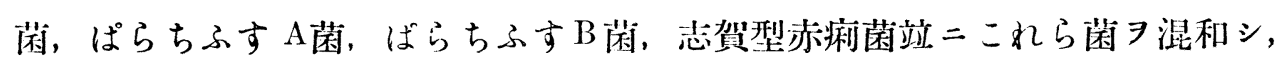

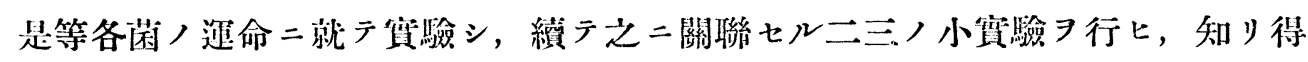
タル事實ヨ總括スレバ次ノ如シ。

1 , 糠味骝八消化器傳染病病原諸菌二對シ殺菌力 7 發揮入。

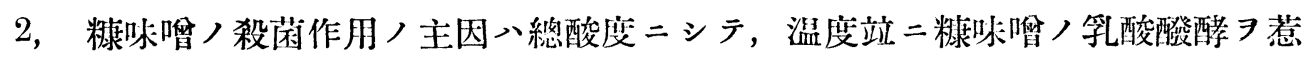

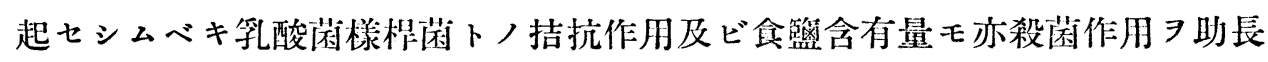
スルモノナリ.

而シテ是等殺菌要約ノ總テア通ジラ供試病原菌中抵抗最モ菁弱ナルハこれら

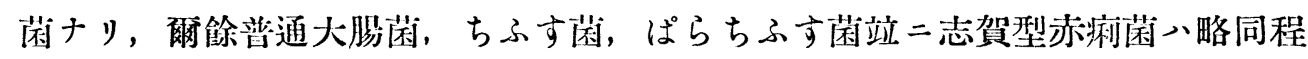

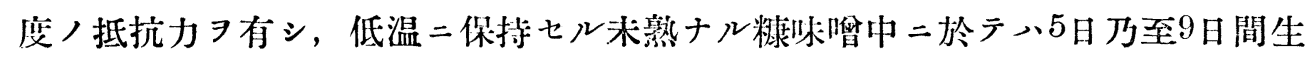

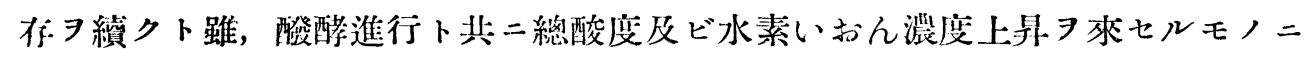
アリテハ, 屢々48時間乃至 72 時間ニシテ死減シ, 稀二72時間後生存スルモノア

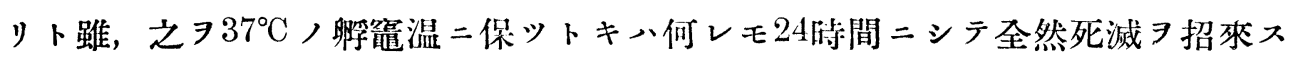
ベシ. 即于夏期温度高ク且成熟七ル粶味噃ニアリテハタト七消化器傳染病病原 菌ノ混入アリトスルモ，1夜ニシラ克ク隇殺七ラルル事貝习捕捉シ得タリ，但

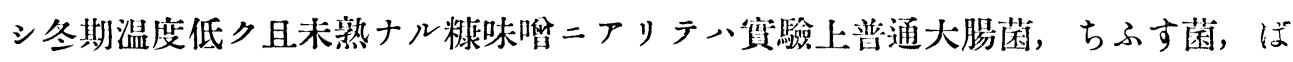

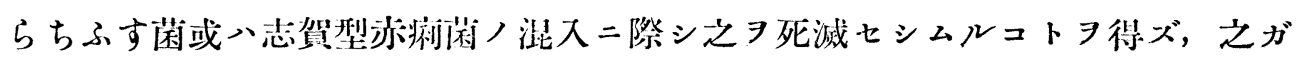
篇病毒蔓延ノ因ヨナスコトアルヨ䍐ハズンバアラズ.

稿 7 終ル二位ミ里見博士: 御愁篤ナル御指導御校閱 $刃$ 深謝ス.

\section{圭要 文 献}

1) W. Kolle, R. Kraus, P, Uhlenhuth, Handbuch d. Patholog. Mikroorganismen, 3 
Auf. Band I 2, III.

2）里胃三男，細菌站二血清學的研究手技，2版.

3) 渡䕗裕， 日本微生物學會雜誌, 16 夋.

4) 同上，同上. 17兊，7號.

5) 同上, 同上. 18 告 3 號.

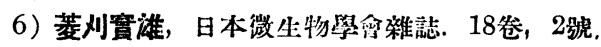

7) 渡遣遺，河谷貫人，

日本微生物學會雜誌。1.8卷, 13䅕。

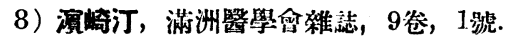

富永哲夫, 日本衛生學傳染病學雜誌. 24兊, 1號.

10）山川房, 國心衛坐。4忩, 9躆.

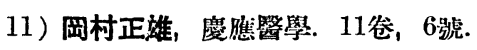

